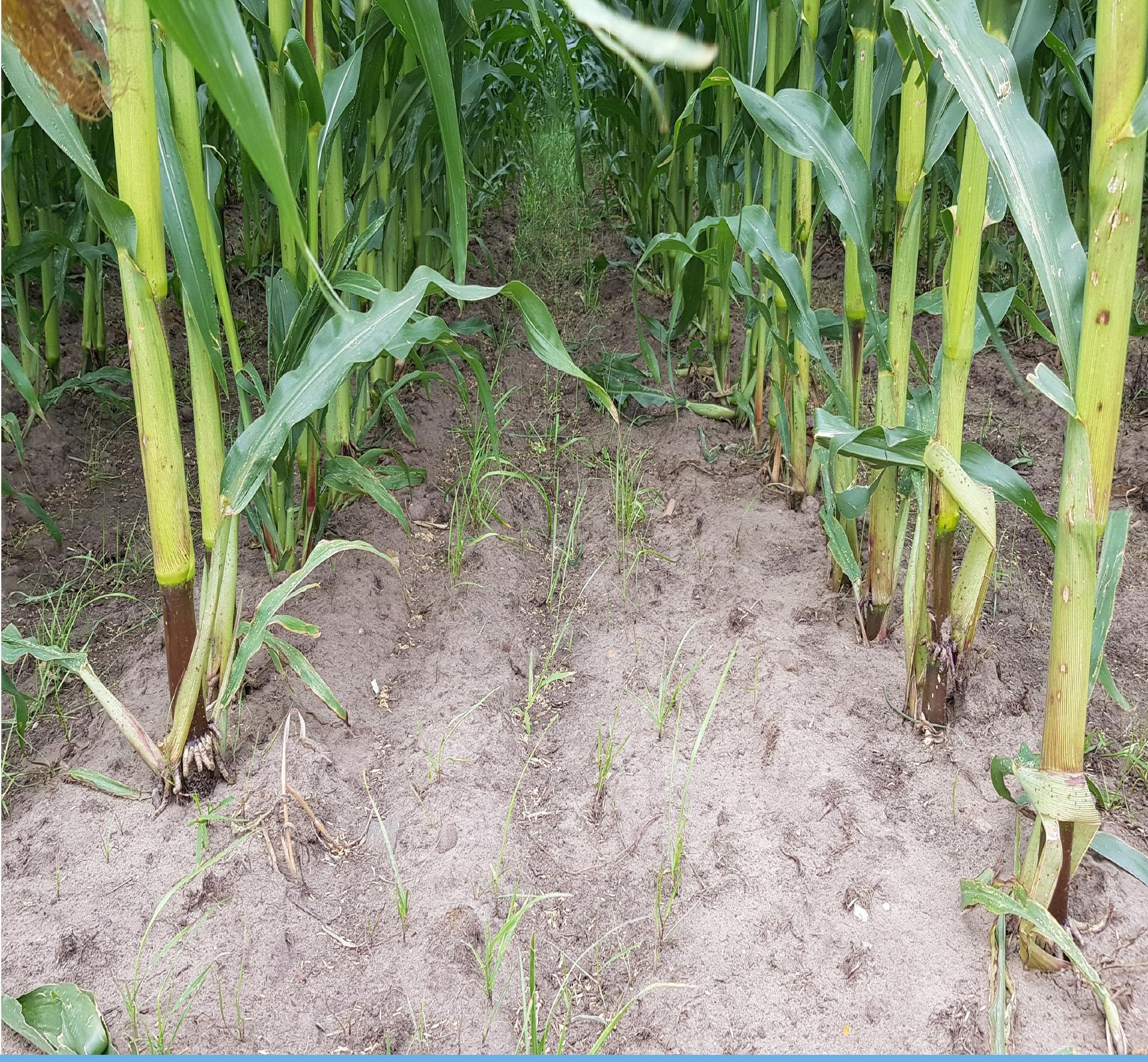

\title{
Eindrapportage Grondig Boeren met Mais Drenthe
}

$2012-2018$

M. Wesselink, J. Specken, H.A. van Schooten, J. Groten, J.T.W. Verhoeven 


\section{Eindrapportage Grondig Boeren met Mais Drenthe}

2012-2018

M. Wesselink ${ }^{1}$, J. Specken ${ }^{1}$, H.A. van Schooten ${ }^{2}$, J. Groten $^{1}$, J.T.W. Verhoeven ${ }^{1}$

1 Wageningen University \& Research - Open Teelten

2 Wageningen Livestock Research

Dit onderzoek is in opdracht van Provincie en Waterschappen uit Drenthe uitgevoerd door de Stichting Wageningen Research (WR), business unit Open Teelten

WR is een onderdeel van Wageningen University \& Research, samenwerkingsverband tussen Wageningen University en de Stichting Wageningen Research.

Wageningen, april 2019

Rapport WPR-809 
Trefwoorden: mais, onderzaai, nazaai, gewasbescherming, bemesting, organische stof

Foto kaft: Onderzaai van Italiaans raaigras in mais, Marwijksoord 2018.

(C) 2019 Wageningen, Stichting Wageningen Research, Wageningen Plant Research, Business unit Open Teelten, Postbus 430, 8200 AA Lelystad; T 03002911 11; www.wur.nl/openteelten CC-BY 4.0 licentie

KvK: 09098104 te Arnhem

VAT NL no. 8113.83.696.B07

Stichting Wageningen Research. Alle rechten voorbehouden. Niets uit deze uitgave mag worden verveelvoudigd, opgeslagen in een geautomatiseerd gegevensbestand, of openbaar gemaakt, in enige vorm of op enige wijze, hetzij elektronisch, mechanisch, door fotokopieën, opnamen of enige andere manier zonder voorafgaande schriftelijke toestemming van Stichting Wageningen Research.

Stichting Wageningen Research is niet aansprakelijk voor eventuele schadelijke gevolgen die kunnen ontstaan bij gebruik van gegevens uit deze uitgave.

Rapport WPR-809
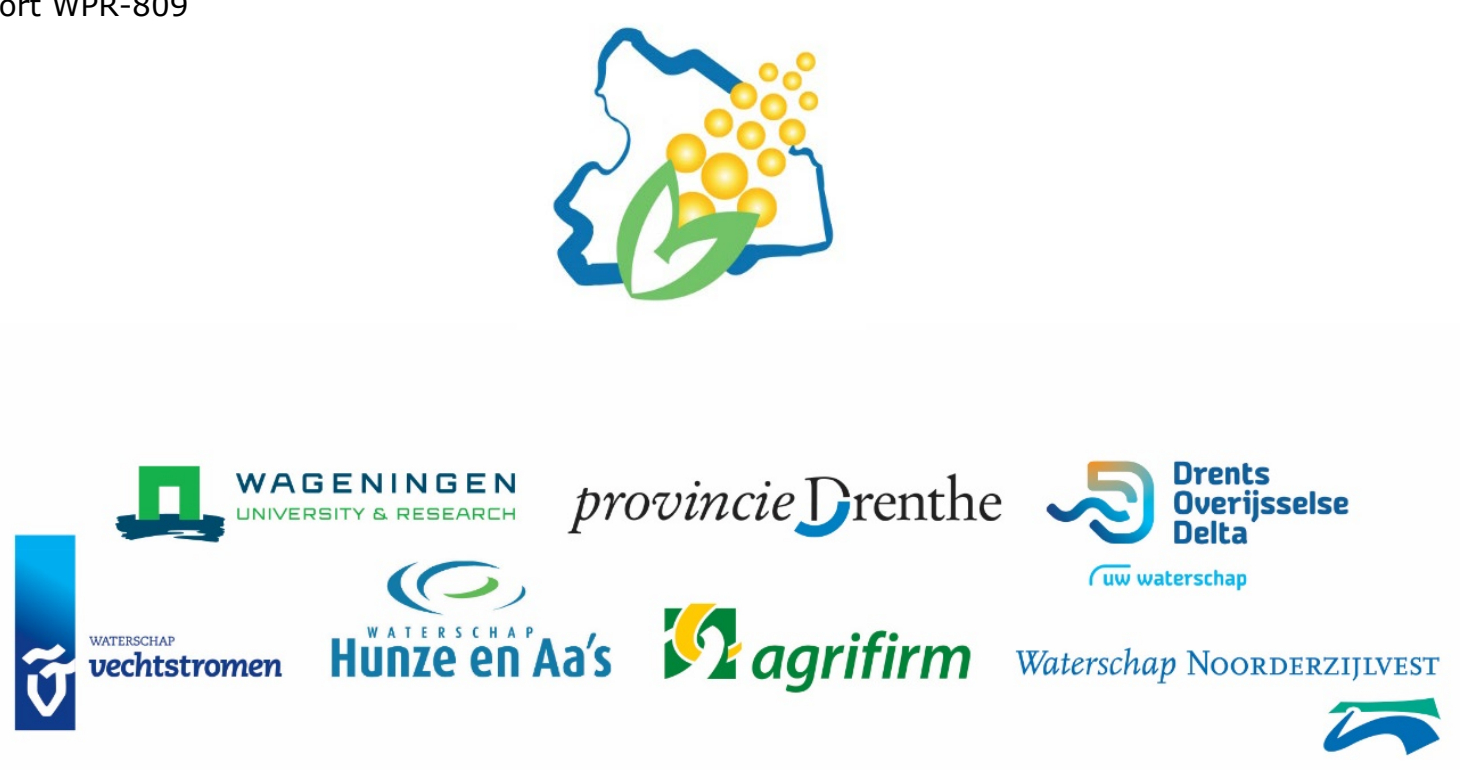

Ministerie van Landbouw,

Natuur en Voedselkwaliteit 


\section{Inhoud}

$\begin{array}{ll}\text { Samenvatting } & 7\end{array}$

1

Inleiding

8

2

$\begin{array}{ll}\text { Methode } & 9\end{array}$

2.1 Systemendemonstratie $\quad 9$

2.1.1 Gangbaar teeltsysteem 10

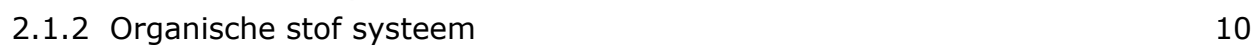

2.1.3 Mineralen uit kringloop systeem 10

2.1.4 Twee oogsten per jaar systeem 11

2.1.5 Vruchtwisseling systeem 11

2.1.6 Metingen en berekeningen 11

$\begin{array}{lll}2.2 & \text { Satellietbedrijven } & 13\end{array}$

$\begin{array}{ll}\text { Resultaten demonstraties Marwijksoord } & 14\end{array}$

$\begin{array}{lll}3.1 & \text { Systemendemonstratie } & 14\end{array}$

3.1.1 Teeltregistratie $\quad 14$

$\begin{array}{ll}3.1 .2 \text { Opbrengst } & 14\end{array}$

$\begin{array}{ll}3.1 .3 \text { Kwaliteit } & 17\end{array}$

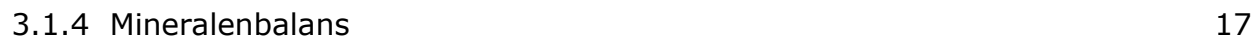

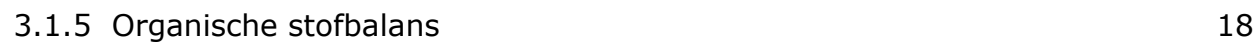

$\begin{array}{ll}3.1 .6 \text { Bodem } & 20\end{array}$

$\begin{array}{ll}3.1 .7 \text { Milieubelastingspunten } & 20\end{array}$

$\begin{array}{ll}3.1 .8 \text { Saldoberekening } & 21\end{array}$

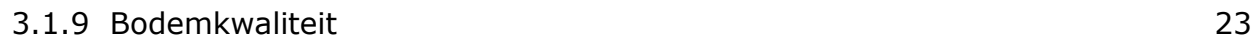

3.1.10Ontwikkelingen over de afgelopen jaren $\quad 23$

3.1.11Indringingsweerstand in de bodem $\quad 26$

3.1.12Biomassa bepalingen vanggewas $\quad 26$

3.2 Detaildemonstraties 29

3.2.1 Detaildemonstratie onderzaai en gewasbescherming 29

3.2.2 Demonstratie alternatieve onderzaaigewassen 31

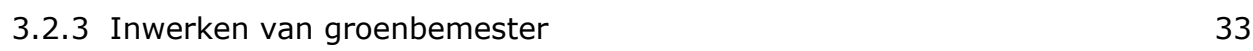

4

$\begin{array}{ll}\text { Satellietbedrijven } & 36\end{array}$

4.1 Graveland $\quad 36$

4.1.1 Huidige methode maïsteelt $\quad 36$

4.1.2 Plan van aanpak 36

4.1.3 Teeltactiviteiten 38

$\begin{array}{ll}4.1 .4 \text { Resultaten } & 39\end{array}$

$\begin{array}{lll}4.2 & \text { Scholten-Reimer } & 44\end{array}$

4.2.1 Huidige methode maïsteelt $\quad 44$

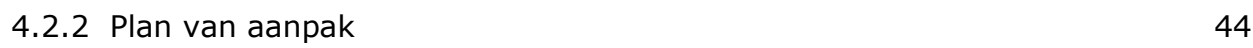

4.2.3 Teeltactiviteiten $\quad 46$

4.2.4 Resultaten $\quad 46$

4.3 Kievit $\quad 50$

4.4 Meijer $\quad 51$

4.5 Tiems $\quad 58$

$\begin{array}{lll}4.6 & \text { Smeenge } & 60\end{array}$ 
$\begin{array}{lll}6.1 & \text { Activiteiten } & 64\end{array}$

6.2 Communicatie $\quad 65$

$\begin{array}{lll}7.1 & \text { Systemendemonstratie } & 67\end{array}$

$\begin{array}{lll}7.2 & \text { Detaildemonstraties } & 67\end{array}$

$\begin{array}{lll}7.3 & \text { Satellietbedrijven } & 68\end{array}$

$\begin{array}{lll}7.4 & \text { Overall } & 68\end{array}$

8

$\begin{array}{ll}\text { Discussie } & 66\end{array}$

8.1 Optreden en verspreiding probleemgrassen 66

8.2 Optreden ziekte $\quad 66$

$\begin{array}{lll}8.3 & \text { Bodemvruchtbaarheid op termijn } & 66\end{array}$

9.1 Drogestof opbrengsten per hectare per systeem voor de jaren 2012-2018 69

9.2 Berekening mineralenbalans $2018 \quad 69$

$\begin{array}{lll}9.3 & \text { Berekening organische stofbalans } 2018 & 71\end{array}$

9.4 Milieubelastingspunten $2018 \quad 72$

$\begin{array}{lll}9.5 & \text { Saldoberekeningen } 2018 & 73\end{array}$

9.6 Bodemparameters per systeem $2014 \quad 74$

$\begin{array}{lll}9.7 & \text { Bodemparameters per systeem } 2018 & 75\end{array}$

9.8 Effect van teeltsystemen op (biologische) bodemparameters 76

$\begin{array}{ll}9.8 .1 \text { Uitvoering } & 76\end{array}$

9.8.2 Chemische bodemvruchtbaarheid $\quad 76$

9.8.3 Microbiologische parameters $\quad 80$

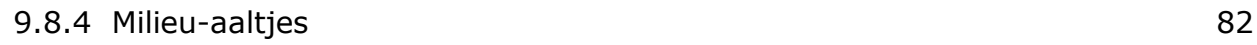





\section{Samenvatting}

In de afgelopen decennia is de maisteelt in toenemende mate in verband gebracht met duurzaamheidsproblemen. Deze hebben te maken met verliezen van nutriënten door af- en uitspoeling, een dalend gehalte aan organische stof in de bodem, een achteruitgang van de biodiversiteit op akkers en de productie van boeikasgassen als lachgas. De opeenstapeling van negatieve aspecten heeft als gevolg dat de maisteelt een duidelijke stap moet zetten in de richting van verduurzaming.

Sinds 2012 wordt er binnen Grondig Boeren met Mais gewerkt aan het verduurzamen van de maisteelt door extra aandacht voor beter bodembeheer met daarbij het streven naar gelijkblijvende opbrengsten. Dit gebeurt vanuit een systemendemonstratie, detaildemonstraties en demovelden bij satellietbedrijven.

Kern in het project is de systemendemonstratie waarbij vijf verschillende manieren van telen in de jaren $2012 \mathrm{t} / \mathrm{m} 2018$ zijn vergelijken. Hierbij is een gangbare manier van telen vergeleken met alternatieve strategieën. Eén van de alternatieve systemen is een object met aandacht voor extra organische stof. Daarnaast is er een object waarbij mineralen uit kringloop worden toegepast. In dit systeem wordt getracht de mineralen in de meest efficiënte vorm toe te passen. Een andere strategie is het twee teelten systeem waarbij eerst een snede gras geoogst wordt, gevolgd door een ultra vroeg maisras. Het vijfde alternatief dat is getoetst is het vruchtwisselingssysteem waarbij 2 jaar grasland word afgewisseld met 2 jaar snijmais.

Uit de systemendemo blijkt na zeven jaar dat er alternatieve maisteeltsystemen zijn waarbij de opbrengst gelijk blijft of zelfs stijgt. De systemen organische stof, mineralen uit kringloop en vruchtwisseling hebben een positief effect op de opbrengst ten opzichte van het standaard systeem. Het organische stof en vruchtwisselingsysteem hebben daarnaast een zeer positieve organische stofbalans, ten opzichte van een ongeveer neutrale balans voor het standaard systeem. Het twee oogsten systeem presteert wisselend, de maisopbrengst blijft in de meeste jaren achter, en de grasopbrengst kan dit verschil vaak niet compenseren. Qua organische stof aanvoer is dit wel een interessant systeem.

Door het telen van jaar op jaar mais op hetzelfde perceel krijgt de systemendemonstratie steeds meer te maken met ziekte. Ook onkruiden zijn een groter worden probleem, en dan met name de grasachtigen die niet meer met bodemherbiciden bestreden kunnen worden in de systemen waar het vanggewas wordt ondergezaaid.

De detaildemo's blijken een goed communicatiemiddel omdat deze duidelijk de effecten van verschillende gewasbeschermingsstrategieën laten zien op het vanggewas bijvoorbeeld. Ook wordt er gekeken naar de mogelijkheden van het mechanisch inwerken van vanggewassen.

In samenwerking met de satellietbedrijven worden innovaties in de praktijk geïmplementeerd en gedeeld met collega maistelers. 


\section{$1 \quad$ Inleiding}

In de afgelopen jaren is de teelt van mais in Nederland in toenemende mate onder druk komen te staan waarbij de nadruk in de teelt komt te liggen op het verduurzamen van de teelt. In de afgelopen jaren worden steeds meer duurzaamheidsproblemen in verband gebracht met de teeltwijze uit de afgelopen decennia. Voorbeelden hiervan zijn verliezen door uitspoeling en afspoeling van nutriënten, verslechtering van de bodemstructuur bij continu maisteelt, een dalend gehalte aan organische stof in de bodem, een achteruitgang van de biodiversiteit op akkers en de productie van boeikasgassen als lachgas. De opeenstapeling van negatieve aspecten heeft als gevolg dat de maisteelt een duidelijke stap moet zetten in de richting van verduurzaming.

Er komt steeds meer aandacht voor circulaire landbouw, de wens is dat de landbouw steeds meer zelfvoorzienend wordt. De visie van LNV hieromtrent onderschrijft dit met onder andere een andere manier van mais telen.

Recentelijke wetgeving zoals het $6^{\mathrm{e}}$ actieprogramma nitraat maken dat er inmiddels (2019) regels zijn ten aanzien van het inzaaien van vanggewassen. Bij maisteelt op zandgrond dient een vanggewas uiterlijk 1 oktober gezaaid te zijn. Ook in de nabije toekomst staat er een wetswijziging aan te komen waarbij het verplicht wordt om per 2021 mest in de rij toe te dienen, met uitzondering van zeer natte gronden. De onderliggende doelstelling vanuit de wetgeving is vooral gericht om de verliezen aan nitraat veroorzaakt door de maisteelt terug te dringen om uiteindelijk te kunnen voldoen aan de nitraatnorm voor grondwater.

Om de problemen in de maisteelt de baas te worden is een stap nodig naar een ander, innovatief teeltsysteem dat genoemde problemen niet heeft. Zo'n ander systeem zou de maïssector helpen een substantiële stap te zetten op het pad naar meer duurzaamheid. Dit nieuwe teeltsysteem bestaat uit een vruchtwisseling met gras, een geslaagde nateelt en een maïs met kortere groeiduur die de nateelt ondersteunt, aangevuld met innovaties als niet-kerende grondbewerking en aangepaste teeltwijze. Dit nieuwe teeltsysteem geeft het gebruikelijke rendement als de standaard teeltwijze, maar draagt bij aan:

- $\quad$ Een betere bodemkwaliteit en structuur met een geleidelijk hoger wordend organisch stofgehalte (koolstof vastlegging) en een lager wordende uitstoot van broeikasgassen (lachgas)

- $\quad$ vermindering van de ziektedruk door bodem- en gewasgebonden ziekten, plagen en onkruiden

- $\quad$ een hogere bodembiodiversiteit

- $\quad$ vermindering van de uit- en afspoeling van nutriënten naar het grond- en oppervlaktewater - $\quad$ een rendabele teeltwijze ook na aanscherping van mineralen gebruiksnormen.

Om deze maatregelen te demonstreren in en aan de praktijk is in 2012 het project Grondig Boeren met Mais opgezet in de provincie Drenthe. In dit project hebben de projectpartners Agrifirm en Wageningen University and Research een demonstratieperceel op WUR proefbedrijf Marwijksoord aangelegd waarin verschillende systeemvarianten getoond worden samen met relevante deelinnovaties. De demonstraties worden ondersteund met waarnemingen om de beoogde (milieu)effecten aan te tonen. Via zomer- en winterbijeenkomsten worden maïstelers en loonwerkers uitgenodigd mee te denken. Via nieuwsbrieven en de website worden inzichten, kennis, en kunde over alternatieve teeltsystemen ingebed in de Drentse maïspraktijk. 


\section{Methode}

Op het WUR proefbedrijf in Marwijksoord liggen de systeemdemonstratie (paragraaf 2.1) en verschillende detaildemonstraties (paragraaf 2.2 ).

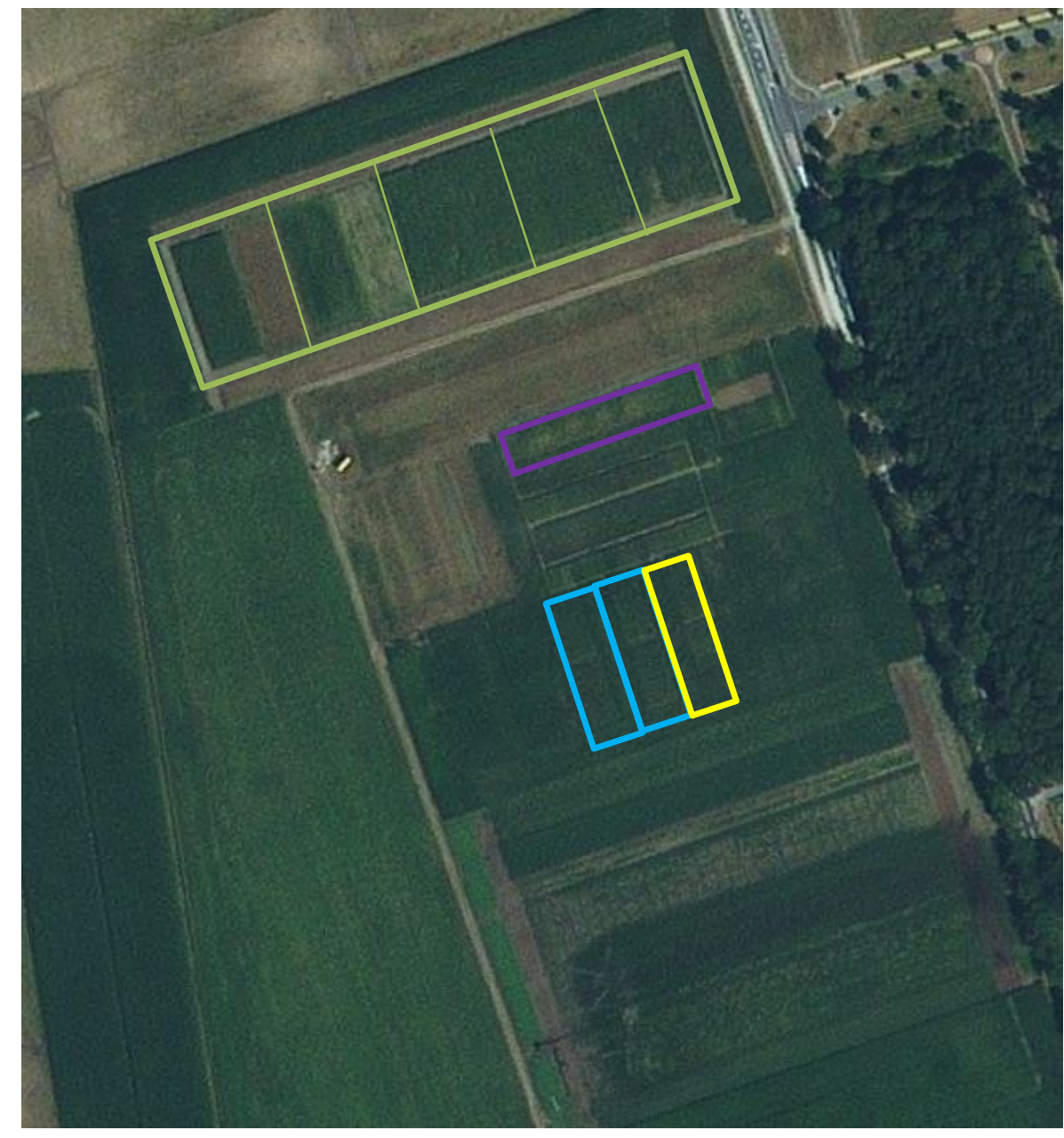

Figuur 1. Satellietbeeld van 23 juli 2018 van het demonstratieperceel in Marwijksoord (www.satellietdataportaal.nl). In lichtgroen omlijnd de verschillende objecten van de systemendemo. In paars de onderwerkdemonstratie; in blauw de gewasbescherming en onderzaai demonstratie en in geel de alternatieve onderzaaigewassen

\subsection{Systemendemonstratie}

Sinds 2012 ligt in Marwijksoord het demonstatieperceel met verschillende teeltsystemen van snijmais. Ook in 2018 zijn deze systemen weer aangelegd. In onderstaande paragrafen worden de systemen individueel toegelicht. 
Tabel 1. Overzicht van de verschillende systemen in 2018.

\begin{tabular}{lllll} 
Systeem & Bemesting & Grondbewerking & Maisras & Vanggewas \\
1 Gangbaar & RDM volvelds & Ploegen $25 \mathrm{~cm}$ & LG31.211 & Nazaai rogge \\
\hline 2 Organische stof & RDM + compost volvelds & Vaste tand $10-15 \mathrm{~cm}$ & LG31.211 & Onderzaai it.raaigras \\
\hline 3 Mineralen uit kringloop & Dunne fractie in de rij & Vaste tand $25 \mathrm{~cm}$ & LG31.211 & Onderzaai it.raaigras \\
\hline 4 Twee oogsten & Gras: zodebemester & Strokenfrees & Asgaard & Nazaai it.raaigras \\
& Mais RDM rij & & & LG31.211 \\
\hline 5 Vruchtwisseling & RDM volvelds & Spitten $25 \mathrm{~cm}$ & Onderzaai it.raaigras
\end{tabular}

\subsubsection{Gangbaar teeltsysteem}

Het gangbare teeltsysteem is gebaseerd op de gebruikelijke manier van mais telen in de regio. In dit systeem wordt rundveedrijfmest geïnjecteerd, kerende grondbewerking in de vorm van ploegen met een vorenpakker toegepast en er wordt een zeer vroeg maisras gezaaid rond 1 mei. Onkruidbestrijding vindt plaats met chemische middelen en op basis van adviesdoseringen. De mais wordt geoogst rond 10 oktober. Naast dat er gekozen wordt voor een zeer vroeg ras is de rassenkeuze gericht op een hoge VEM opbrengst. Circa één week na de oogst wordt rogge ingezaaid als vanggewas, omdat dit is voorgeschreven door de wet.

\subsubsection{Organische stof systeem}

Dit systeem is gericht op aanvoer van organische stof om de bodem te verbeteren. Eén van de nadelen bij de gangbare maïsteelt is een negatieve organische stofbalans. De aanvoer van verse organische stof is daar lager dan de jaarlijkse afbraak van organische stof. Omdat er bij de teelt van snijmaïs nagenoeg geen gewasresten achterblijven en er steeds minder drijfmest kan worden toegepast, verschraalt het bodemleven en gaat het organische stofgehalte van de bouwvoor langzaam achteruit.

Om de aanvoer van organische stof te verbeteren wordt in dit systeem een deel van de rundveedrijfmest vervangen door compost. Er wordt ook hier voor een zeer vroeg ras gekozen, omdat deze in het algemeen eind september oogstrijp zijn. Om ook de maximale hoeveelheid organische stof uit het vanggewas te halen wordt er gras ondergezaaid rond het 4-bladstadium. Het wintergewas wordt zo een vanggewas en een groenbemester. Onkruidbestrijding werd toegepast met een lage dosering systeem, en bij de grasinzaai werd er geschoffeld.

\subsubsection{Mineralen uit kringloop systeem}

In het mineralen uit kringloop systeem wordt geprobeerd om de voor handen zijnde nutriënten in een zo efficiënt mogelijke vorm toe te passen. De verhouding tussen stikstof en fosfaat in mest sluit namelijk niet goed aan op de bemestingsnormen voor snijmaïs. Er zit relatief te veel fosfaat in de mest waardoor extra stikstof in de vorm van kunstmest moet worden gegeven. Door gebruik te maken van de dunne fractie, digestaat en andere vormen van restproducten, kan de maïs volledig met meststoffen uit kringloop producten worden bemest. Het gebruik van kunstmest is hierdoor overbodig of kan tot een minimum worden beperkt. In 2018 is er gebruik gemaakt van bewerkte mest van een teler in de regio die de dikke fractie afvoert. Uit de analyse bleek echter dat deze mest qua P-gehalte en ratio $\mathrm{N}$-mineraal en $\mathrm{N}$-org nauwelijks afweek ten opzichte van onbewerkte rundveedrijfmest. 
Tabel 2. Overzicht van gebruikte mest en N en P-gehaltes per systeem.

\begin{tabular}{llrrrrr} 
& & \multicolumn{5}{c}{$\mathrm{kg} / \mathrm{ton}$} \\
Systeem & Mestsoort & $\mathrm{N}$-tot & Nmin & Norg & $\mathrm{P}_{2} \mathrm{O}_{5}$ & $\mathrm{~K}_{2} \mathrm{O}$ \\
1. Standaard & RVDM & 3.86 & 2 & 1.9 & 1.15 & 6.7 \\
\hline 2. Org. stof & RVDM & 3.86 & 2 & 1.9 & 1.15 & 6.7 \\
\hline 3. Mineralen uit kringloop & RVDM dunne fractie & 3.48 & 1.7 & 1.8 & 1.21 & 4.3 \\
\hline 4. Twee oogsten & RVDM & 4.12 & $\mathrm{nb}$ & $\mathrm{nb}$ & 0.82 & 4.69 \\
\hline 5. Vruchtwisseling & RVDM & 3.86 & 2 & 1.9 & 1.15 & 6.7 \\
\hline
\end{tabular}

In dit systeem wordt niet alleen geprobeerd de verhouding van verschillende nutriënten zo optimaal mogelijk gemaakt, ook de toediening. De meststoffen werden met een GPS gestuurde bouwlandinjecteur op $75 \mathrm{~cm}$ geïnjecteerd en de maïs werd met GPS boven de mestinjectie stroken gezaaid. Gecombineerd met minimale grondbewerking werd ook nog eens minder energie gebruikt. De kwaliteiten van het vanggewas (groenbemester) werden ook in dit systeem optimaal benut door onderzaai van een grasgroenbemester in juni. Bij de onkruidbestrijding werd een lage dosering systeem (LDS) gebruikt, afhankelijk van soorten en ontwikkeling van onkruiden op het moment van bestrijding, en met de grasinzaai werd er geschoffeld. Na de oogst, eind september, neemt de groenbemester de overgebleven mineralen uit de bodem op en tilt deze over de winter heen. Deze komen in het volgende teeltseizoen weer beschikbaar.

\subsubsection{Twee oogsten per jaar systeem}

Op het demoperceel werd in dit systeem nog meer ruimte gegeven aan de groenbemester gras-klaver. In het vroege voorjaar werd deze met een zodebemester bemest zodat deze begin mei een oogstbare snede had. Dit eiwitrijkere product is een mooie aanvulling voor het rantsoen. Een gevolg was wel dat de maïs laat werd gezaaid en vroeg werd geoogst. Dit is alleen mogelijk met een Ultra vroeg maïsras. In het voorjaar werd, na de oogst van de grasklaver, de zode doodgespoten en bemest met rundveedrijfmest in de rij. Vervolgens werd er met een strokenfreesmachine van Zandvliet gezaaid. Een deel van het object is gezaaid met de ondergrondse ploeg van Henk van de Pol. Na inzaaien is er 1 keer chemische onkruidbestrijding toegepast. Na de maïsoogst (half september) werd raaigras nagezaaid.

\subsubsection{Vruchtwisseling systeem}

Op dit perceel in de demonstratie werd vruchtwisseling toegepast van grasklaver met snijmaïs. Om het mogelijk te maken beide gewassen (gras en mais) tegelijkertijd te monitoren is dit perceel opgedeeld in twee delen. Op een deel staat grasklaver voor 2 jaar en op het andere deel 2 jaar maïs. Bij het maïs deel werd in het voorjaar de zode doodgespoten waarna deze werd ondergespit gevolgd door inzaai van ultra vroege snijmaïs. Wanneer het jaar erop nog een keer maïs ingezaaid wordt vindt er gras onderzaai plaats, anders wordt een mengsel van raaigras en rode klaver nagezaaid. Dit jaar betrof het maisobject een $2^{\mathrm{e}}$ jaars mais. Er wordt 1 keer een chemische onkruidbestrijding toegepast, met een lage dosering systeem.

\subsubsection{Metingen en berekeningen}

Van alle systemen wordt een teeltregistratie bijgehouden. Hierin worden tijdstippen van handelingen zoals bemesting, zaai, onkruidbestrijding en oogst bijgehouden. Ook worden er gedurende het groeiseizoen waarnemingen gedaan.

In alle systemen worden bij de oogst opbrengstbepalingen gedaan, van zowel de mais als eventueel het gras. Van de geoogste mais wordt een monster genomen dat op droge stof en voederwaarde geanalyseerd wordt door Eurofins Agro, hetzelfde gebeurt voor het geoogste gras. 
In 2018 zijn er voor het eerst Nmin monsters genomen na de oogst, dit om een beeld te krijgen van de hoeveelheid stikstof achtergebleven in de bodem.

In het voorjaar van 2019 zijn biomassabepalingen verricht aan de groenbemesters. Hierbij is van zowel bovengronds als ondergronds de biomassa bepaald en het drogestofgehalte. De ondergrondse monsters zijn eerst schoon gespoeld.

Ook is de indringingsweerstand gemeten met behulp van een penetrologger.

Met behulp van de verzamelde gegevens worden van elk systeem mineralen- en organische stofbalansen opgesteld. Op basis van de gebruikte gewasbeschermingsmiddelen en hoeveelheden worden de milieubelastingspunten per systeem berekend. Ook wordt van elk systeem een saldoberekening gemaakt op basis van de kosten op opbrengsten per systeem. 


\subsection{Satellietbedrijven}

Ook in 2018 zijn er demonstraties aangelegd op zes verschillende satellietbedrijven in de regio. Figuur 2 geeft de ligging van de verschillende bedrijven op de kaart weer. In hoofdstuk 4 worden de verschillende demonstraties en resultaten per satellietbedrijf besproken.

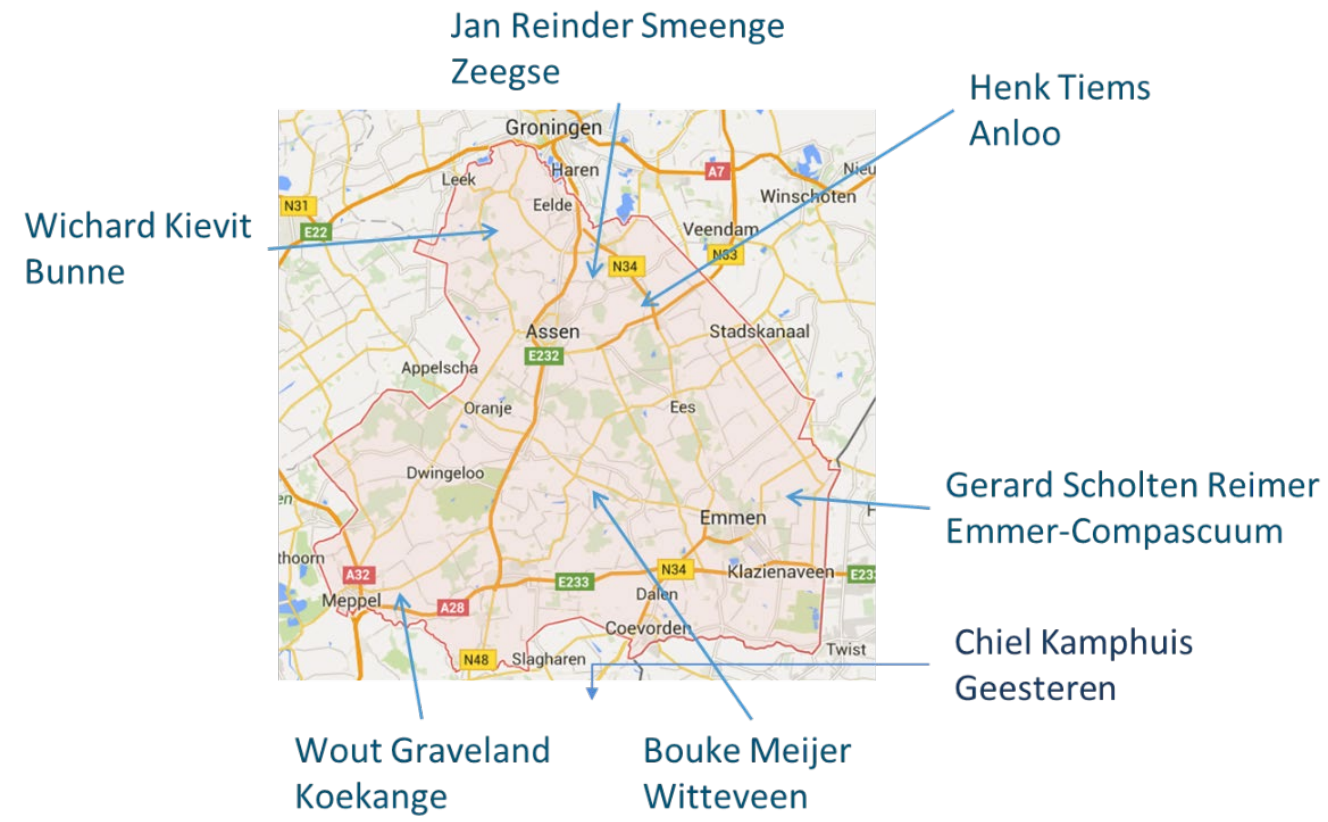

Figuur 2. Ligging van de satellietbedrijven in de provincie Drenthe. 


\section{Resultaten demonstraties Marwijksoord}

Bij de interpretatie van de resultaten is het belangrijk te realiseren dat het gaat om metingen aan demonstraties die niet in herhalingen uitgevoerd zijn. Hierdoor zijn geen statistische verschillen te berekenen en kunnen er geen harde conclusies verbonden worden aan de waargenomen verschillen, maar wel indicaties voor ontwikkelingen over de jaren, in het geval van de systemendemonstratie. Zoals in bijlage 9.6 en 9.7 te lezen is was het gehele perceel waarop de systemendemonstratie is aangelegd niet homogeen bij aanvang, het perceel vertoont een organische stof gradiënt. Dit compliceert het doen van uitspraken. Wel ondersteunen ze de communicatie rond de verschillende teeltsystemen en geven de richting aan van de ontwikkeling van de verschillende parameters.

Het groeiseizoen 2018 was een bijzondere. Het voorjaar begon vroeg, met enkele flinke buien rond de zaai van de mais (13 mei met $53 \mathrm{~mm}$ water in korte tijd) die plaatselijk wateroverlast hebben veroorzaakt. De demo zelf ondervond nauwelijks schade hiervan. Wel werd besloten om de dichtgeslagen grond te schoffelen; ook bij het object waar geen onderzaai is gedaan. Vervolgens werd het droog, en bleef het droog. Ook werd het zeer warm. Vanwege deze omstandigheden is de mais tweemaal beregend ( 25 juli en 8 augustus met beiden $30 \mathrm{~mm}$ ). Door de hoge temperaturen is de mais sneller ontwikkeld dan normaal, en ook eerder geoogst.

\subsection{Systemendemonstratie}

\subsubsection{Teeltregistratie}

In het vroege voorjaar is het vanggewas in de systemen Gangbaar, Organische stof, Mineralen uit kringloop en Vruchtwisseling doodgespoten met glyfosaat. Van het Twee oogsten systeem is eerst een snede gras geoogst, waarna de zode begin mei eveneens is doodgespoten. Alle systemen zijn bemest en vervolgens heeft de hoofdgrondbewerking plaatsgevonden. Het standaard systeem is geploegd terwijl de systemen organische stof en mineralen uit kringloop zijn losgetrokken met een vaste tand+ vorenpakker. Op 9 mei is in alle systemen behalve het twee oogsten systeem mais gezaaid. In dit systeem is op 24 mei gezaaid. Onkruidbestrijding in het gangbare systeem vond plaats op 5 juni met 1.5 Calaris + 0.75 Samson + 1 Frontier. Het organische stof systeem, mineralen uit kringloop en het vruchtwisseling systeem zijn op 31 mei gespoten met 0.5 Calaris +0.5 Samson. Vervolgens is in deze systemen op 14 juni Italiaans raaigras ondergezaaid. Omdat de grond was dichtgeslagen bij alle objecten als gevolg van de neerslag, is ook het standaard object (waar geen onderzaai gepland was), geschoffeld om zo lucht in de grond te brengen. Het twee oogsten systeem is op 5 juni gespoten met 0.5 Calaris. Op 25 juli, $7 / 8$ augustus is er beregend, $25 \mathrm{~mm}$ per keer. Op 12 september is alle mais geoogst. Op 24 september is in het gangbare systeem rogge gezaaid. In het twee oogsten systeem is op 24 september Italiaans raaigras nagezaaid.

\subsubsection{Opbrengst}

In de systemen gangbaar, organische stof, mineralen uit kringloop en vruchtwisseling wordt hetzelfde zeer vroege ras ingezaaid (LG 31-211), om de uiteindelijke opbrengsten beter met elkaar te kunnen vergelijken. Vanwege de aard van het systeem wordt er in het dubbelteelt systeem gekozen voor een ultravroeg ras. In 2018 was dat het ras Asgaard. 
In alle systemen is de mais geoogst op 12 september. Dat er zo vroeg geoogst kon worden, lag aan het extreme groeiseizoen. $\mathrm{Er}$ is dit jaar geen onderscheid gemaakt in oogstmoment tussen het zeer vroege en het ultravroege ras. Het vroegere maisras in het twee oogsten systeem was matig ontwikkeld maar vrijwel gelijktijdig rijp met de overige objecten. Figuur 3 geeft de maisopbrengsten van 2018 weer. Deze resultaten zijn gebaseerd op 2 opbrengstbepalingen per systeem.

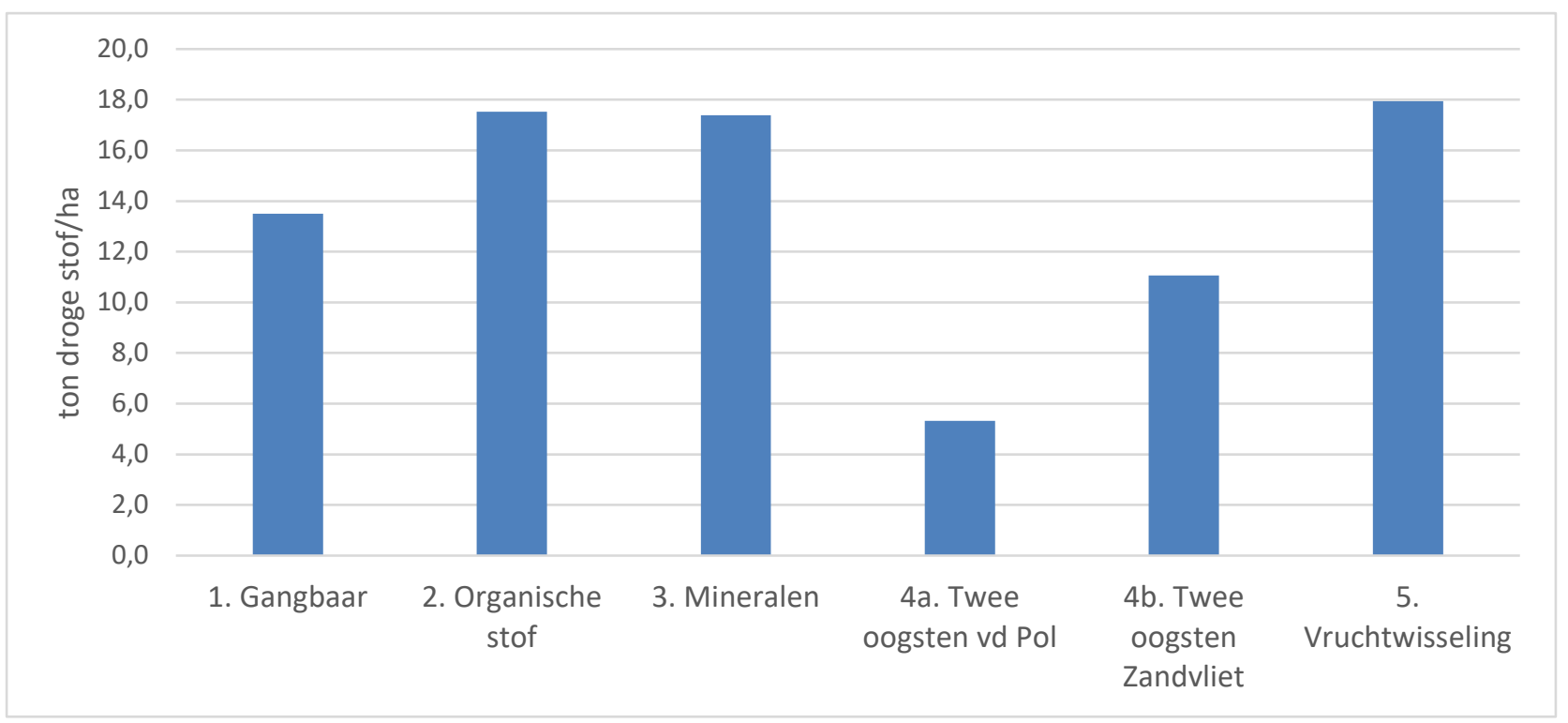

Figuur 3. Gemiddelde mais opbrengst 2018 per systeem in ton ds/ha.

De systemen organische stof, mineralen uit kringloop en vruchtwisseling hebben in 2018 een goede opbrengst gehaald van rond de 18 ton droge stof per hectare. Gezien de omstandigheden van dit jaar is dit hoog. Het gangbare systeem blijft hierop achter met een opbrengst van ruim 13 ton. Deze opbrengst komt overeen met vergelijkbare praktijkpercelen (ongeveer 14 ton). De opbrengst van het twee oogsten per jaar systeem is het laagst. Deels is dit verklaarbaar, omdat hier een vroeger ras geteeld is en omdat de grasopbrengst er nog bij opgeteld moet worden. Maar ook kwam de mais op dit systeem vanwege de droogte lastig tot ontwikkeling. De grasopbrengst voorafgaand aan de mais was 2 ton droge stof per hectare. Wanneer voor het Zandvliet deel de gras en maisopbrengsten opgeteld worden komt de totale opbrengst overeen met het gangbare systeem. Het deel ingezaaid met de machine van Van der Pol blijft in dat geval nog steeds erg achter op alle andere systemen. 


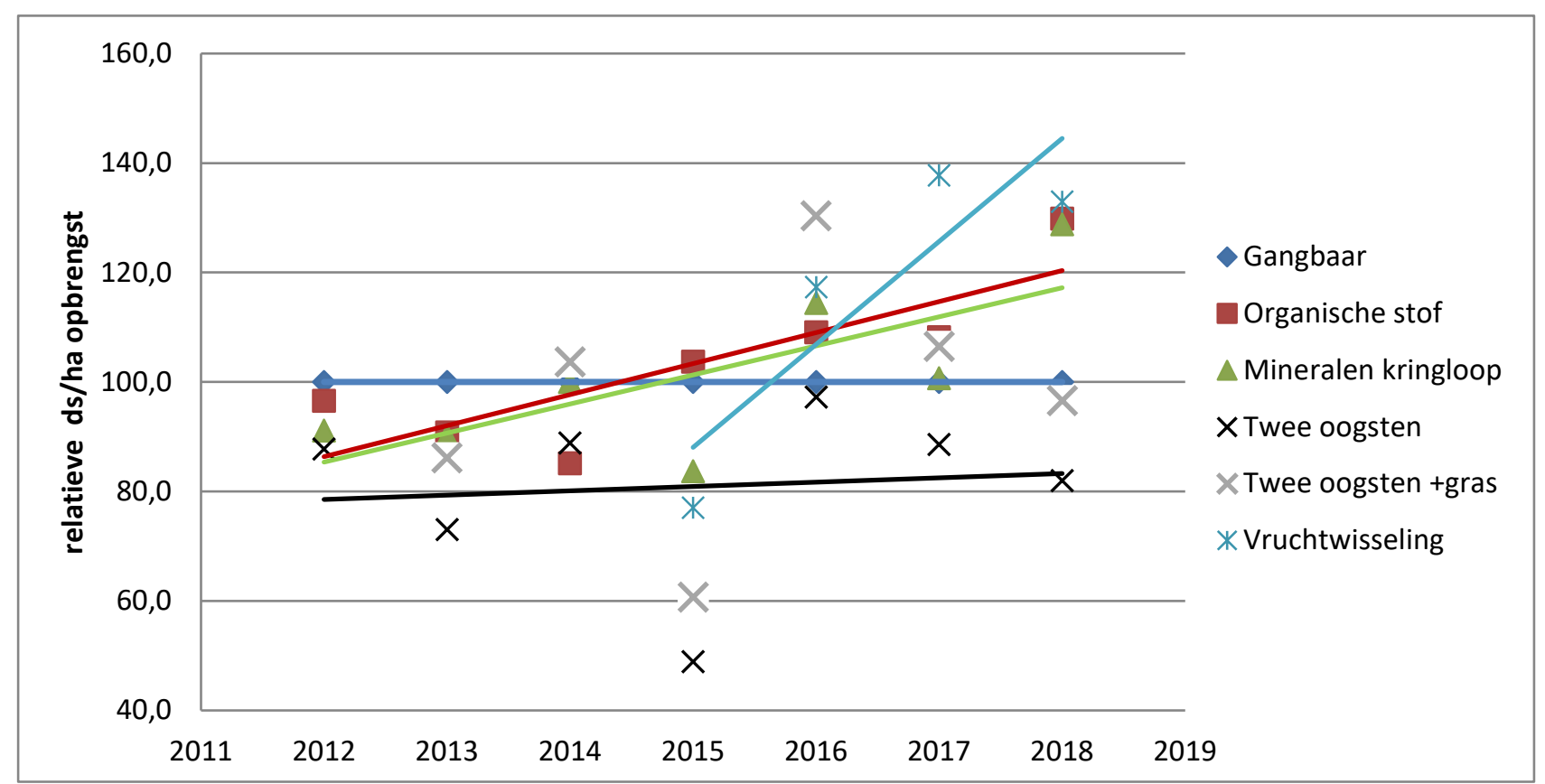

Figuur 4. Relatieve droge stof opbrengsten van de verschillende systemen over de periode 2012-2018 waarbij gangbaar $=100 \%$.

Figuur 4 geeft het verloop van de droge stofopbrengsten over 2012-2018 relatief weer. De opbrengsten voor het gangbare systeem zijn voor ieder jaar op 100 gezet, absolute opbrengsten van dit systeem zijn weergegeven in Tabel 3. Hierin zijn ook de grasopbrengsten voor het twee oogsten systeem weergegeven. De absolute maisopbrengsten van alle systemen van alle jaren zijn weergegeven in Bijlage 9.1.

De resultaten van 2018 zijn in lijn met de trend van de afgelopen jaren. De alternatieve maisteeltsystemen organische stof, mineralen uit kringloop en vruchtwisseling laten een positieve trend zien ten opzichte van het gangbare systeem. Het twee oogsten systeem ligt gemiddeld op een vergelijkbare opbrengst als het gangbare systeem, alleen de variatie is enorm. Deze variatie geeft daarmee gelijk de moeilijkheid in het management van dit systeem weer, het blijkt nog niet altijd gemakkelijk om het gras onder controle te krijgen. Dit was bijvoorbeeld het geval in 2015. Het vruchtwisseling systeem laat de grootste (relatieve) stijging zien over de afgelopen jaren. De opbrengst van 2018 ligt hier iets lager dan in 2017. Mogelijk stabiliseert de opbrengst in dit systeem zich rond deze waarde.

Tabel 3. Absolute opbrengsten van het gangbare systeem, en de grasopbrengsten van het twee oogsten en vruchtwisseling systeem, beide in ton ds/ha. Het vruchtwisselingsysteem bestaat pas sinds 2015.

\begin{tabular}{lrrrrrrrr} 
& 2012 & 2013 & 2014 & 2015 & 2016 & 2017 & 2018 \\
Mais opbrengst gangbaar & 14.7 & 15.2 & 16.2 & 13.5 & 15.4 & 15.0 & 13.5 \\
\hline Gras opbrengst twee oogsten & - & 2.0 & 2.4 & 1.6 & 5.1 & 2.7 & 2.0 \\
\hline Gras opbrengst vruchtwisseling & - & - & - & 11.6 & 13.5 & 11.2 & 8.0 \\
\hline
\end{tabular}

In Tabel 3 zijn ter vergelijking de droge stofopbrengsten van het grasdeel van het vruchtwisseling systeem weergegeven. In totaal is hier 8 ton gras geoogst in 2018. Dit is veel minder dan de voorgaande jaren. De extreem droge en warme weersomstandigheden liggen hieraan ten grondslag. Door de droogte is er nauwelijks gras van de $3^{\mathrm{e}}$ en $4^{\mathrm{e}}$ snede geoogst. 


\subsubsection{Kwaliteit}

Van alle systemen zijn op 2 plekken uit het perceel monsters genomen en geanalyseerd op gewaskwaliteit door Eurofins Agro. Gemiddeldes hiervan zijn weergegeven in Tabel 4. De kwaliteit van de mais in de systemen gangbaar, organische stof, mineralen uit kringloop en vruchtwisseling is goed, en vergelijkbaar tussen de systemen. Het twee oogsten systeem, en dan met name het Van der Pol deel, blijft achter in kwaliteit. De mais in dit systeem was minder rijp dan in de andere systemen.

Tabel 4. Gemiddelde droge stof gehalte, VEM en zetmeel gehaltes en totalen per ha (in ton) per systeem in 2018.

\begin{tabular}{|c|c|c|c|c|c|c|c|}
\hline & $\begin{array}{c}\text { Vers } \\
\text { opbrengst }\end{array}$ & $\begin{array}{l}\text { ds } \\
\%\end{array}$ & $\begin{array}{l}\text { ton } \\
\text { ds/ha }\end{array}$ & VEM & VEM/ha & Zetmeel & Zetmeel/ha \\
\hline 1. Gangbaar & 38.9 & 34.4 & 13.5 & 1067.5 & 14.4 & 369.5 & 5.0 \\
\hline 2. Organische stof & 49.7 & 35.0 & 17.5 & 1054.0 & 18.5 & 358.0 & 6.3 \\
\hline 3. Mineralen kringloop & 48.9 & 35.7 & 17.4 & 1046.0 & 18.2 & 351.0 & 6.1 \\
\hline 4a. Twee oogsten vd Pol & 19.1 & 28.3 & 5.3 & 998.0 & 5.3 & 307.5 & 1.6 \\
\hline 4b. Twee oogsten Zandvliet & 35.7 & 31.0 & 11.1 & 1019.0 & 11.3 & 348.0 & 3.8 \\
\hline 5. Vruchtwisseling & 54.1 & 33.2 & 17.9 & 1001.5 & 18.0 & 299.0 & 5.4 \\
\hline
\end{tabular}

\subsubsection{Mineralenbalans}

In Figuur 5 is de mineralenbalans van zowel totale stikstof $(\mathrm{N})$ als fosfaat $\left(\mathrm{P}_{2} \mathrm{O}_{5}\right)$ weergegeven.

Achterliggende gegevens zijn terug te vinden in Bijlage 9.1. Bij de berekening van de mineralenbalans is gerekend met de totale toegediende hoeveelheden en niet het werkzame deel. Bij de bemesting van de verschillende systemen is het uitgangspunt dat elk systeem evenveel werkzame $\mathrm{N}$ en $\mathrm{P}_{2} \mathrm{O}_{5} \mathrm{krijgt}$. Er is

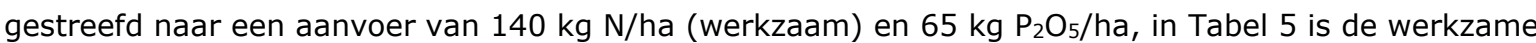
hoeveelheid $\mathrm{N}$ weergegeven. Tabel 6 geeft de hoeveelheid $\mathrm{P}_{2} \mathrm{O}_{5}$ weer.

Tabel 5. Hoeveelheid aangevoerde werkzame stikstof (wettelijk) per systeem per hectare per jaar.

\begin{tabular}{llllllll} 
& 2012 & 2013 & 2014 & 2015 & 2016 & 2017 & 2018 \\
1 Gangbaar & 123 & 140 & 141 & 142 & 149 & 135 & 124 \\
\hline 2 Organische stof & 130 & 150 & 139 & 143 & 141 & 105 & 100 \\
\hline 3 Mineralen uit kringloop & 150 & 148 & 142 & 144 & 144 & 144 & 140 \\
\hline 4 Twee oogsten & 146 & 140 & 147 & 144 & 145 & 143 & 129 \\
\hline 5 Vruchtwisseling maïs & & & & 142 & 141 & 92 & 82
\end{tabular}

Tabel 6. Hoeveelheid aangevoerde fosfaat (P2O5) per systeem per hectare per jaar.

\begin{tabular}{llllllll} 
& $\mathbf{2 0 1 2}$ & $\mathbf{2 0 1 3}$ & $\mathbf{2 0 1 4}$ & $\mathbf{2 0 1 5}$ & $\mathbf{2 0 1 6}$ & $\mathbf{2 0 1 7}$ & $\mathbf{2 0 1 8}$ \\
1 Gangbaar & 60 & 67 & 53 & 56 & 56 & 63 & 29 \\
\hline 2 Organische stof & 84 & 99 & 56 & 69 & 64 & 90 & 76 \\
\hline 3 Mineralen uit kringloop & 60 & 116 & 87 & 56 & 50 & 50 & 61 \\
\hline 4 Twee oogsten & 60 & 60 & 58 & 56 & 58 & 72 & 39 \\
\hline 5 Vruchtwisseling maïs & & & & 56 & 60 & 54 & 25
\end{tabular}

Uit Tabel 5 valt af te lezen dat de streefhoeveelheid van $140 \mathrm{~kg}$ werkzame stikstof per hectare in 2018 niet voor alle systemen wordt gehaald. Bij het vruchtwisselingsysteem is dit te verklaren omdat we rekening houden met de nawerking van de ingewerkte graszode. Voor de andere systemen zijn de verschillen kleiner, en deels te verklaren door de variërende $\mathrm{N}$-gehaltes in de toegediende mest die op voorhand niet altijd bekend waren. Voor de hoeveelheid aangevoerde fosfaat (Tabel 6) geldt hetzelfde. Het organische stofsysteem en het mineralen uit kringloop systeem komen redelijk in de buurt van de 
$65 \mathrm{~kg} \mathrm{P} \mathrm{O}_{5} / \mathrm{ha}$, de andere drie systemen blijven hier ver onder. Deels is dit te verklaren door het lage fosfaatgehalte in de gebruikte rundveedrijfmest $(0.82 \mathrm{~kg} / \mathrm{ton})$.

Door de over het algemeen wat lagere hoeveelheden aangevoerde stikstof en fosfaat in 2018 worden de gemiddelde balansen over 2012-2018 iets minder positief en/of iets meer negatief (Figuur 5). De verschillen tussen de systemen blijven hetzelfde. De balans voor het vruchtwisseling systeem geeft misschien een vertekend beeld, omdat in dit geval de mineralenbalans van de maisteelt van dit systeem is weergegeven.

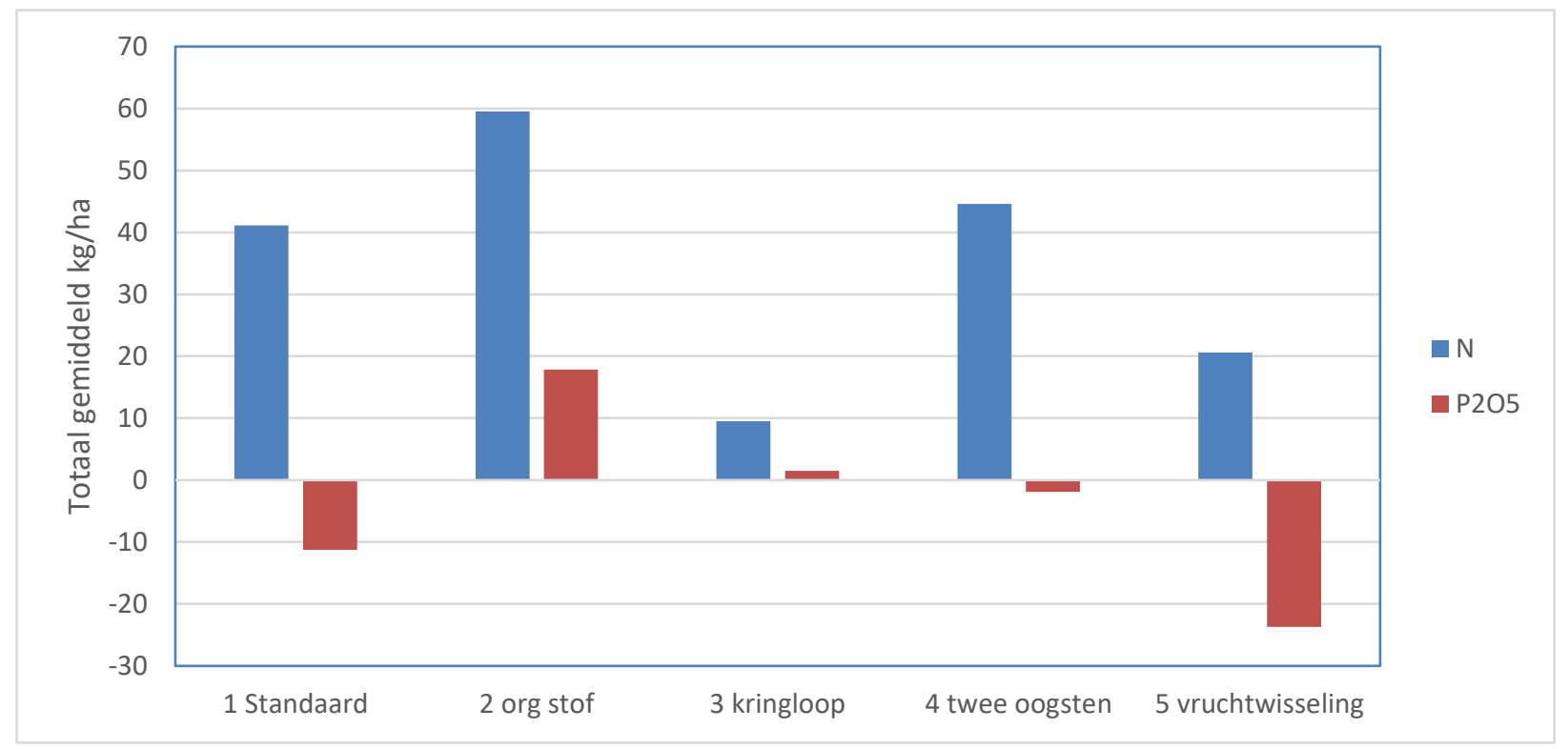

Figuur 5. Mineralenbalansen voor de verschillende systemen gemiddeld voor de jaren 2012-2018

\subsubsection{Organische stofbalans}

In Figuur 6 is de organische stofbalans per systeem weergegeven voor 2018. De achterliggende kengetallen en berekeningen hiervoor zijn terug te vinden in Bijlage 9.3. Het mineralen uit kringloop systeem laat een licht negatieve balans zien. De aanvoer van organische stof is hier dan ook minimaal, door het gebruik van de dunne fractie in plaats van bijvoorbeeld rundveedrijfmest. In het organische stof systeem is duidelijk het effect van het gebruik van compost terug te zien in de zwaar positieve balans. In het twee oogsten systeem en het grasdeel van het vruchtwisseling systeem wordt het positieve effect van grasteelt op de organische stofbalans duidelijk zichtbaar. 


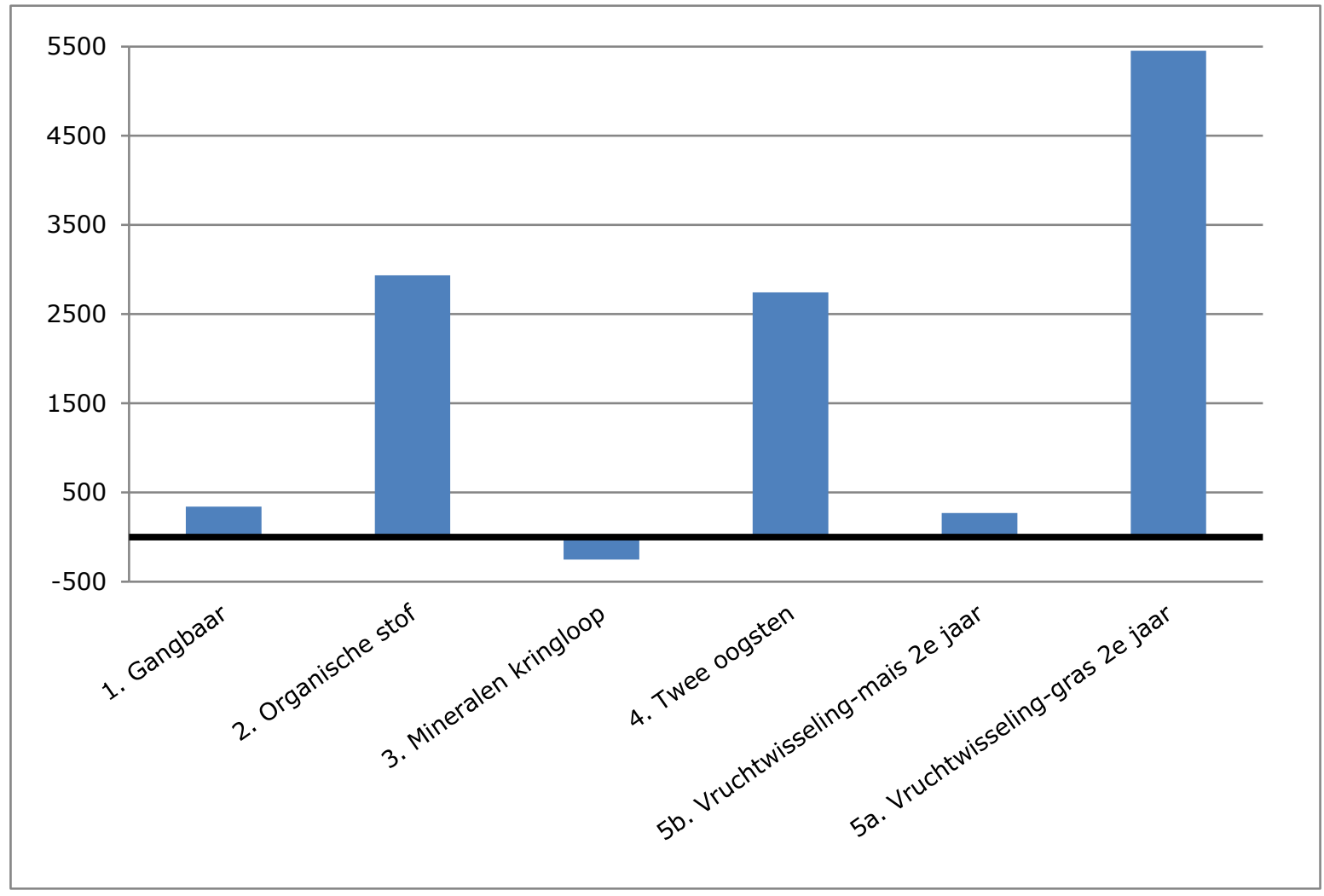

Figuur 6. Organische stofbalansen voor de verschillende systemen in 2018.

Figuur 7 is vergelijkbaar met Figuur 6, alleen in dit geval worden de gemiddelde balansen voor 20122018 weergegeven. Over de jaren heen is een vergelijkbaar verschil tussen de systemen te zien als in 2018; het mineralen uit kringloop systeem heeft een licht negatieve balans, het gangbare systeem een lichte positieve organische stofbalans. Het organische stofsysteem, mineralen uit kringloop en vruchtwisseling-gras hebben een zeer positieve balans. De maisteelt in het vruchtwisseling systeem verschilt niet zoveel van de gangbare maisteelt. Op een perceel zal de gemiddelde organische stofbalans voor een vruchtwisseling systeem een gemiddelde zijn tussen het mais- en grasdeel.

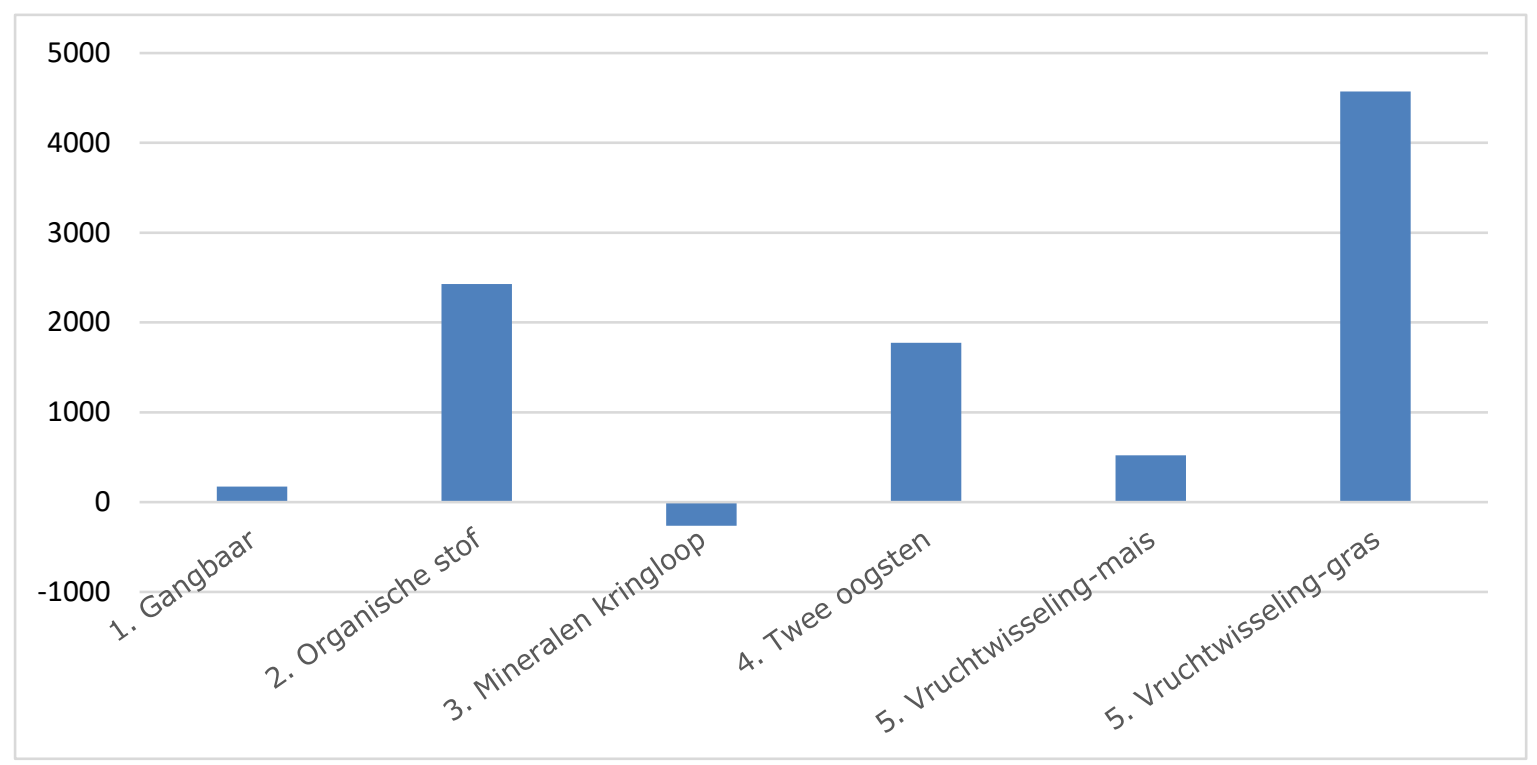

Figuur 7. Gemiddelde organische stofbalansen voor de verschillende systemen (2012-2018). In het geval van het vruchtwisseling systeem (5a en 5b) gemiddeld over 2015-2018. 


\subsubsection{Bodem}

$\mathrm{Na}$ de oogst van de mais is er op 4 september 2018 in elk teeltsysteem een Nmin monster gestoken van de laag 0-30 cm. Resultaten hiervan staan in Tabel 7. De Nmin is het hoogst in het gangbare systeem, hier is dus na de teelt de meeste stikstof achtergebleven in de bodem. Het mineralen uit kringloop en het twee oogsten systeem hebben de laagste Nmin. Voor het mineralen uit kringloop systeem zou de opbrengst een verklaring kunnen zijn, deze was 4 ton hoger dan het gangbare systeem. Het twee oogsten systeem had daarentegen een vergelijkbare opbrengst met het gangbare systeem (wanneer de grasopbrengst ook wordt meegenomen), dus die redenatie gaat hier niet op. Ook de hoeveelheid aangevoerde werkzame stikstof is vergelijkbaar tussen deze twee systemen. In het gangbare systeem wordt het vanggewas nagezaaid, en het lijkt erop dat deze niet meer in staat was om de achtergebleven stikstof op te nemen.

Tabel $7 \quad$ N-mineraal na oogst van de vijf maisteeltsystemen in Marwijksoord in 2018

\begin{tabular}{ll}
$\begin{array}{ll}\text { Systeem } \\
1 \text { Gangbaar }\end{array}$ & $\begin{array}{l}\mathrm{N} \text {-mineraal } 0-30 \mathrm{~cm} \\
(\mathrm{~kg} / \mathrm{ha})\end{array}$ \\
\hline 2 Organische stof & 29 \\
\hline 3 Mineralen uit kringloop & 17 \\
\hline 4 Twee oogsten & 17 \\
\hline 5 Vruchtwisseling & 42 \\
\hline
\end{tabular}

\subsubsection{Milieubelastingspunten}

Bij de berekening van de milieubelastingpunten (MBP) voor de toepassing van de gewasbeschermingsmiddelen bij de verschillende teeltsystemen zijn de volgende uitgangspunten gebruikt:

- $\quad$ Berekening is gedaan met de milieumeetlat open teelten (www.milieumeetlat.nl)

- De op de verschillende systemen toegepaste middelen (herbiciden) en doseringen zijn ingevoerd. Deze zijn allemaal in het voorjaar (mrt - aug ) toegepast. Het aantal milieubelastingspunten voor grondwater is afhankelijk van het tijdstip van toepassing. Bij toepassing in het najaar is het risico van uitspoeling namelijk groter dan bij toepassing in het voorjaar.

- Grondsoort heeft klasse 3-6\% organische stof. De Milieumeetlat houdt rekening met het organische stofpercentage in de bodem. Het gehalte organische stof is namelijk net als de middeleigenschappen (zoals afbraaksnelheid en binding aan bodemdeeltjes) bepalend voor de hoeveelheid bestrijdingsmiddel dat na verloop van tijd in de bodem achterblijft. Deze concentratie in de bodem bepaalt samen met de giftigheid het risico dat het middel voor het bodemleven vormt.

- $\quad$ Om vergelijking tussen de jaren mogelijk te maken is de berekeningsmethode van 2015 toegepast voor alle jaren.

Tabel 8 geeft de samenvatting van de milieubelastingspunten per systeem over het jaar 2018. In bijlage 9.4 worden de details (middelen + hoeveelheid actieve stof) per systeem voor 2018 weergegeven. Het gangbare systeem heeft duidelijk de hoogste belasting op het milieu, dit komt overeen met de resultaten van de afgelopen jaren (Figuur 8 ). In de alternatieve systemen wordt er geen gebruik gemaakt van bodemherbiciden, om de onderzaai van het vanggewas beter te laten slagen. Daarnaast wordt de onkruidbestrijding in deze systemen volgens het lage dosering systeem (LDS) gedaan, en wordt er dus minder middel gebruikt. Gemiddeld over 2012-2018 hebben de alternatieve teeltsystemen ongeveer de helft van de milieubelastingpunten ten opzichte van gangbaar. 
Tabel 8. Milieubelastingspunten (MBP) per systeem opgesplitst in water, bodemleven en grondwater voor 2018.

\begin{tabular}{lcccc} 
& MBP Water & MBP bodemleven & MBP grondwater & MBP totaal \\
1. Gangbaar & 340 & 92 & 92 & 524 \\
\hline 2. Organische stof & 121 & 39 & 38 & 198 \\
\hline 3. Mineralen uit kringloop & 121 & 39 & 38 & 198 \\
\hline 4. Twee oogsten & 52.5 & 38 & 23 & 114 \\
\hline 5. Vruchtwisseling & 121 & 39 & 38 & 198 \\
\hline
\end{tabular}

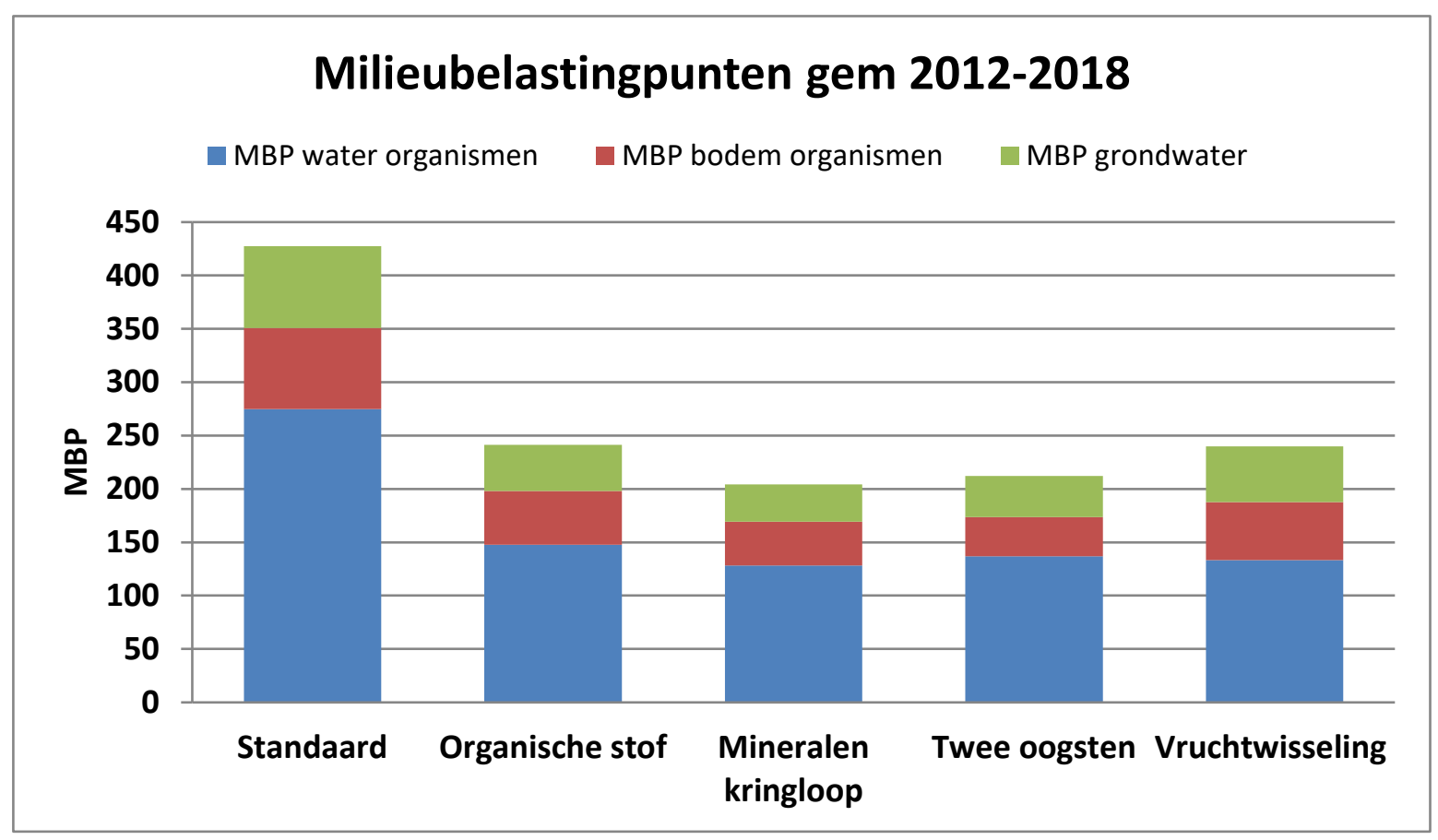

Figuur 8. Gemiddelde milieubelastingspunten per systeem over de periode 2012-2018, voor het vruchtwisselingsysteem over de periode 2015-2018.

\subsubsection{Saldoberekening}

Van elk systeem wordt jaarlijks een saldoberekening gemaakt. De financiële opbrengst van elk systeem wordt bepaald door de maisopbrengst en de eventuele oogst van de groenbemester (gras/klaver) als ruwvoer. Aan de kostenkant zijn de middelen (zaaizaad, meststoffen en gewasbeschermingsmiddelen) en de teeltmaatregelen (loonwerk) meegenomen. Details van deze berekening zijn terug te vinden in Bijlage 9.5. Figuur 9 geeft de samenvatting per systeem voor het jaar 2018. 


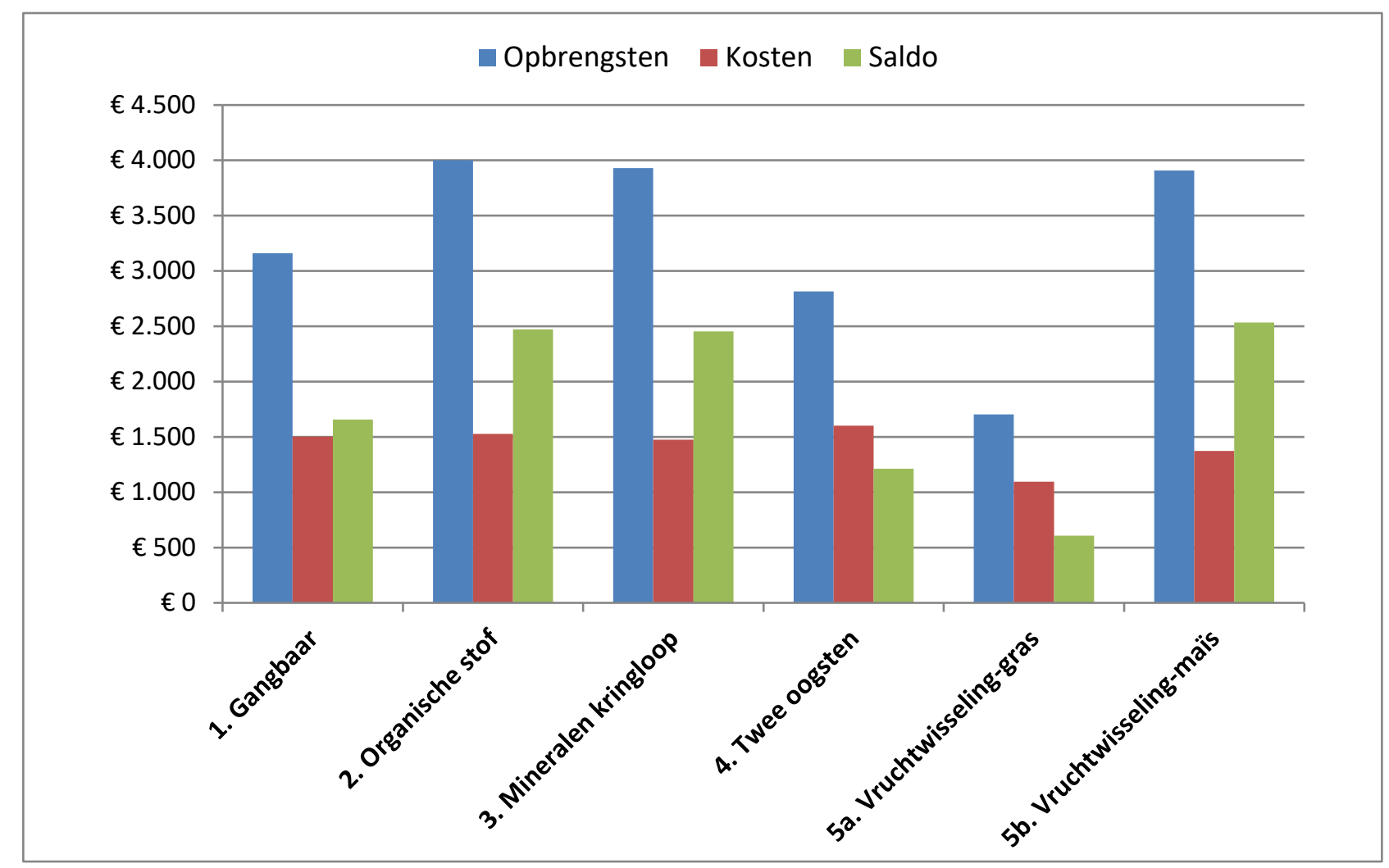

Figuur 9. Opbrengsten, kosten en saldo per teeltsysteem in euro's per hectare in 2018.

De verschillen in saldo tussen de verschillende systemen zijn groot. Het saldo is het hoogst voor het vruchtwisseling systeem waar in 2018 mais geteeld werd ( $€ 2536,-)$ en het laagst voor het grasdeel van het vruchtwisseling systeem ( $€ 608,-)$. Van de maisteeltsystemen is het saldo het laagst voor het twee oogsten systeem ( $€ 1211,-)$. De verschillen in saldo worden voornamelijk veroorzaakt door de verschillen in opbrengst, de kosten van de verschillende systemen liggen dichter bij elkaar.

Wanneer de saldoberekeningen van de verschillende systemen over de jaren gemiddeld worden zijn de verschillen tussen de systemen veel genuanceerder (Figuur 10), de grote variatie in opbrengst wordt hier grotendeels weggemiddeld.

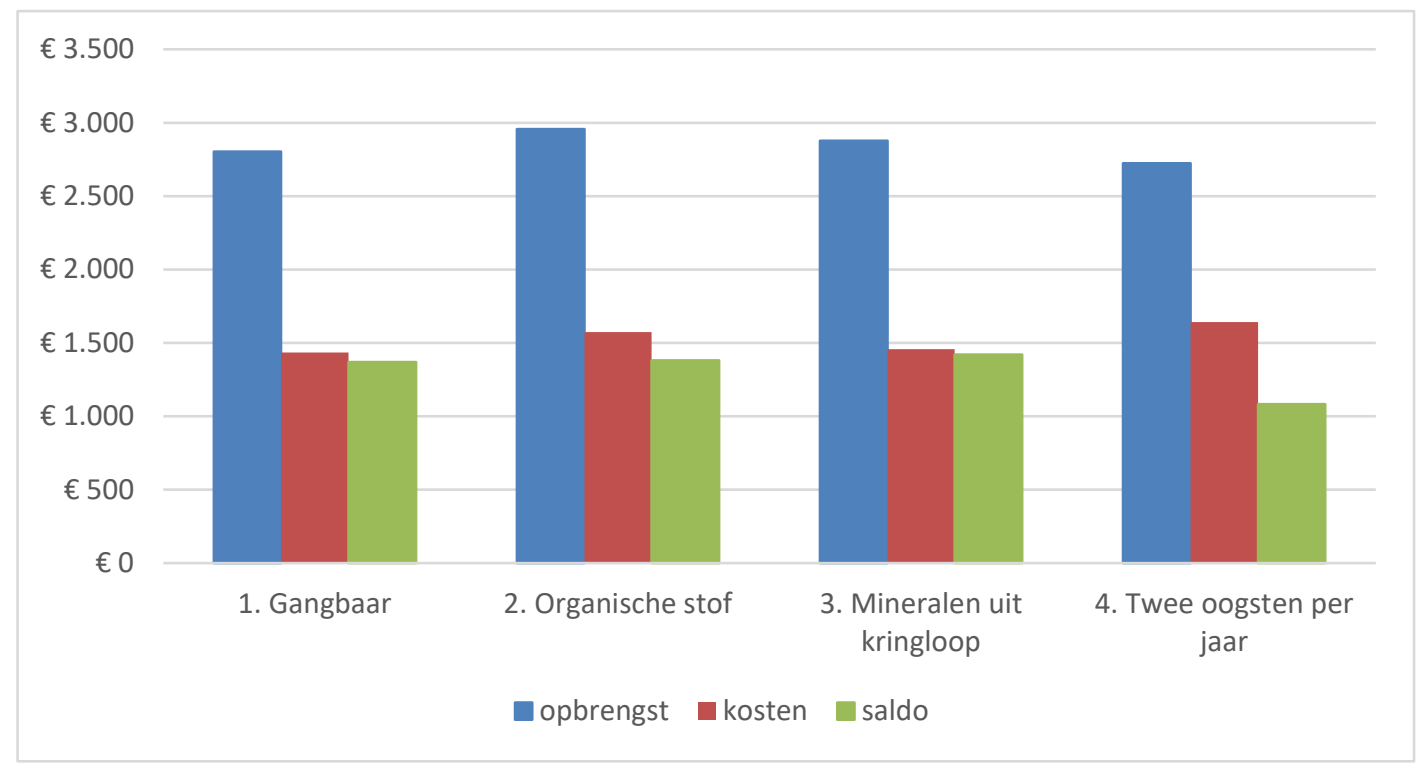

Figuur 10. Gemiddelde opbrengsten, kosten en saldo per systeem in euro's per hectare over de jaren 2012-2018. 


\subsubsection{Bodemkwaliteit}

Over de jaren zijn er op verschillende momenten metingen gedaan aan de bodemkwaliteit. In bijlages 9.6, 9.7 en 9.8 zijn de resultaten hiervan te vinden. Hieronder de samenvatting.

Veranderingen in de bodem verlopen vaak langzaam. Een periode van zes jaar is nog relatief kort en waarschijnlijk voor een aantal parameters (o.a. organische stof) nog niet lang genoeg om al betrouwbare effecten van de systemen te kunnen meten. Daarnaast is het aantal waarnemingen binnen een systeem (systemen zijn in enkelvoud aangelegd) en het aantal waarnemingen in de tijd nog vrij beperkt. Ook zijn de meetmomenten (tijdstip in het jaar) niet gelijk waardoor variatie in de metingen kan ontstaan, wat het betrouwbaar vaststellen van effecten of trends lastig maakt.

Desondanks zijn er wel verschillen tussen de systemen waargenomen. De teeltmaatregelen in het systeem ORGANISCHE STOF lijken op een aantal parameters, waarvan een relatie met de bodemkwaliteit (bodemgezondheid) wordt verondersteld, een positief effect te hebben. In zowel oktober 2014 als in november 2016 en februari 2019 worden in het systeem ORG. STOF hogere waarden voor potentieel mineraliseerbare stikstof (PMN), Hot Water extractable Carbon (HWC) en schimmelbiomassa gemeten in vergelijking tot systeem STANDAARD. PMN is een maat voor gemakkelijk afbreekbare stikstof, en wordt wel gezien als een goed indicator voor de totale microbiologische biomassa en bodemvruchtbaarheid. HWC lijkt goed te correleren met microbiële koolstof en wordt wel gezien als een goede maat voor "bodemkwaliteit". Hogere waarden wijzen op meer bodemleven en een grotere bodemvruchtbaarheid. Beide parameters laten in andere langjarige veldexperimenten een positieve correlatie zien met onder andere de gewasopbrengsten.

Het verschil in samenstelling van de nematodenpopulatie tussen de systemen ORG. STOF en STANDAARD is (nog) relatief klein. Wel zijn het aantal nematoden die behoren tot de hogere cp-klasse in het systeem ORG. STOF wat hoger dan in het STANDAARD systeem, wat zou kunnen duiden op de ontwikkeling naar een meer stabielere (minder verstoorde) bodem.

Er zijn verschillen in chemische bodemvruchtbaarheid tussen het standaard en organische stof systeem. De mineralen gehalten zijn in systeem ORG. STOF gemiddeld hoger dan in het systeem STANDAARD. Het is op basis van het beperkt aantal metingen (in de tijd) niet aan te geven of deze verschillen al het gevolg zijn van de teeltmaatregelen of veroorzaakt worden door de spreiding in de metingen (meetfout) en de natuurlijke variatie binnen het perceel/systeem, die bij aanleg van de systemen al werd geconstateerd. Gezien het verschil in os tussen beide systemen en de wetenschap dat oS gehalte maar langzaam veranderen is het de vraag of de verschillen tussen de systemen (die we waarschijnlijk al vanaf de aanleg van de demo meten) het effect zijn van de teeltmaatregelen of een gevolg van variatie in het perceel. De verschillen tussen de systemen zijn over een aantal jaren stabiel, je zou verwachten dat er trends ontstaan. Dit zou er ook op kunnen duiden dat de verschillen eerder het gevolg zijn van variatie in het perceel dan ontstaan zijn door de teeltmaatregelen die zijn uitgevoerd.

Als er echte verschillen tussen de systemen ontstaan, zullen die de komende jaren naar verwachting groter worden en betrouwbaar te meten zijn. Door de teeltsystemen voort te zetten en periodiek bodemanalyses uit te voeren kan worden vastgesteld of de nu waarneembare trends zich doorzetten. Hebben de maatregelen in het systeem ORG. STOF een positief effect op de bodemkwaliteit/-gezondheid en wat zijn de effecten hiervan op de gewasproductie en andere bodemfuncties?

Belangrijk is om een vast monstermoment te kiezen zodat mogelijke effecten van tijdstip van bemonsteren op de diverse parameters zoveel mogelijk worden beperkt waardoor mogelijke effecten (trends) eerder/beter zichtbaar worden.

\subsubsection{Ontwikkelingen over de afgelopen jaren}

In de afgelopen jaren is in de systemen 2, 3 en 5 waar wordt ondergezaaid, een toenemende druk van gladvingergras vastgesteld. Gladvingergras is moeilijk te bestrijden met de beschikbare grassenmiddelen en omdat er geen bodemherbicide toegepast kan worden in combinatie met onderzaai in het 4-6 
bladstadium, is bestrijding ervan lastig. In het afgelopen jaar bleek de druk van gladvingergras dusdanig dat er op bepaalde perceelsgedeeltes handmatig moest worden gewied.

Om het gladvingergras ook in de komende jaren beheersbaar te houden, zal er worden gekeken naar een combinatie van mechanische en chemische bestrijding door de mais voor opkomst te eggen.

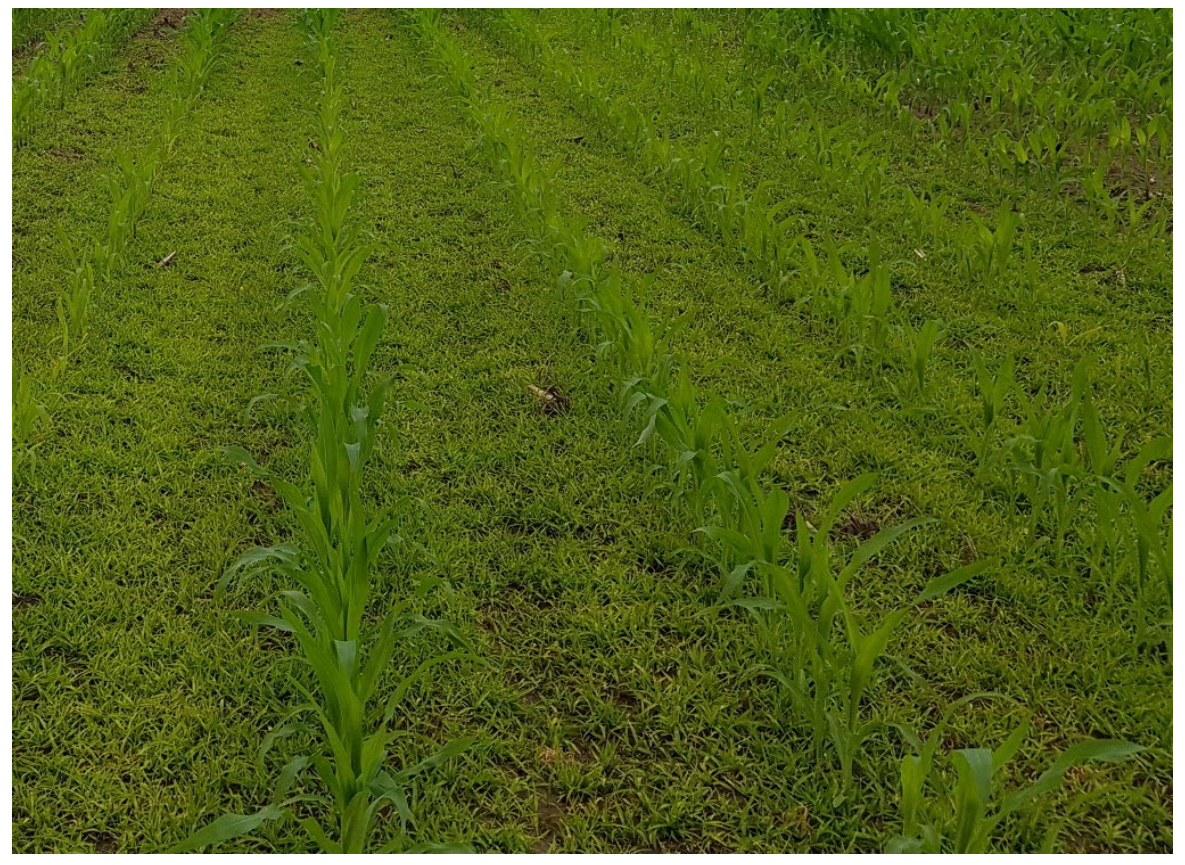

Figuur 11. Gladvingergras in de mais.

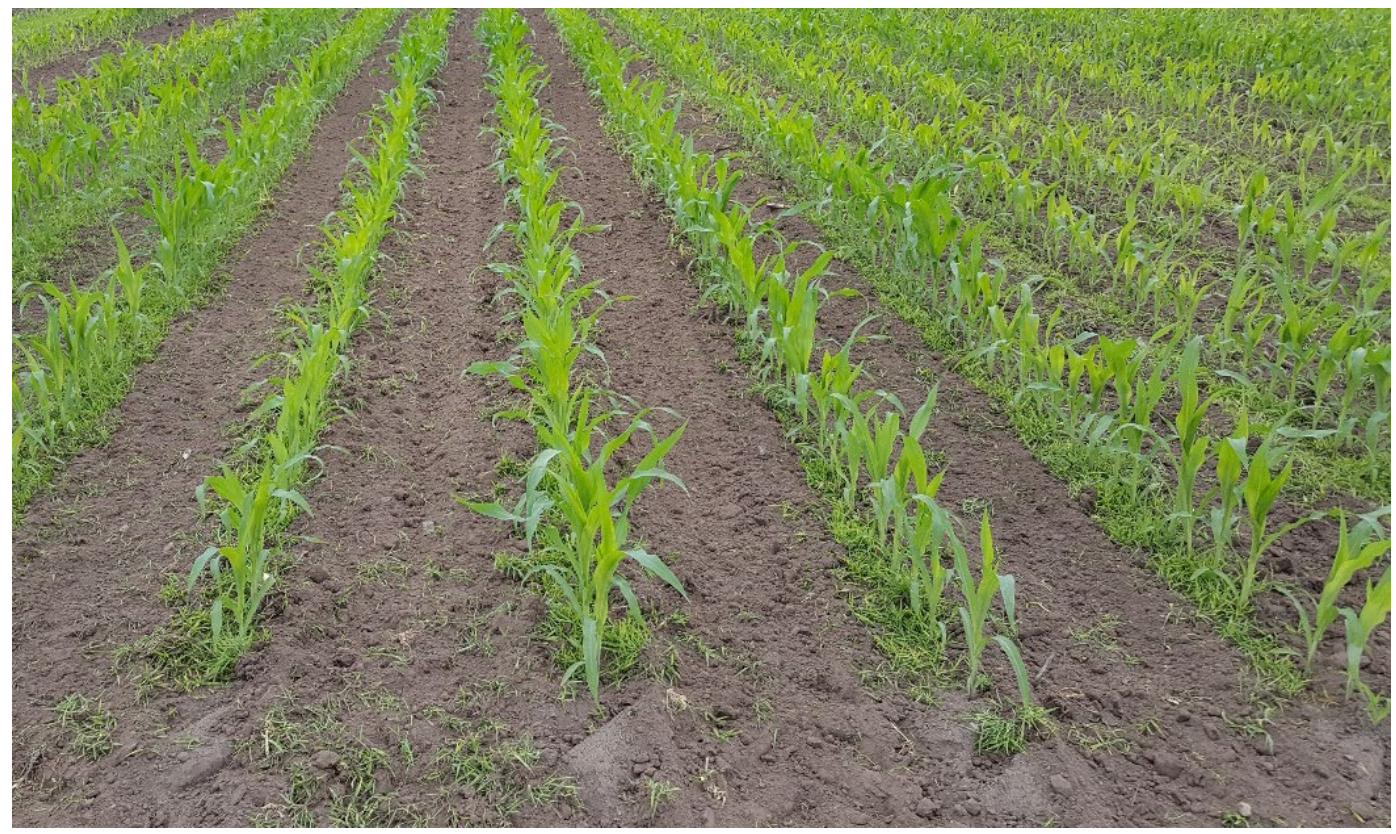

Figuur 12. Gladvingergras na schoffelen. In de maisrij blijft veel achter.

Een ander verschijnsel in het perceel is het optreden van een ziektebeeld in de systemen gangbaar, extra organische stof en het systeem met mineralen uit kringloop. Hierbij lijkt het alsof de planten onder het grondoppervlakte worden afgesnoerd met een verkurking van de wortelhals tot gevolg. Bovengronds tonen de planten een verkleuring naar geel-wit en blijven de planten achter in groei (Figuur 13 en Figuur 
14). Het gangbare object toont dit ziektebeeld het sterkst terwijl de symptomen minder sterk zijn in de objecten met extra organische stof en het object met mineralen uit kringloop.

Om dit ziektebeeld te kunnen koppelen aan de ziekteverwekker, zijn in de afgelopen jaren meerdere analyses uitgevoerd. Hierbij is gekeken naar nutriënten, aaltjes, en er is een DNA-scan uitgevoerd. Dit leidde echter niet tot de oorzaak. In het voorjaar van 2018 zijn kort na opkomst planten met het ziektebeeld verzameld en aangeboden aan de NVWA. De NVWA concludeerde op grond van een visuele beoordeling van planten dat het om Rhizoctonia spp ging.

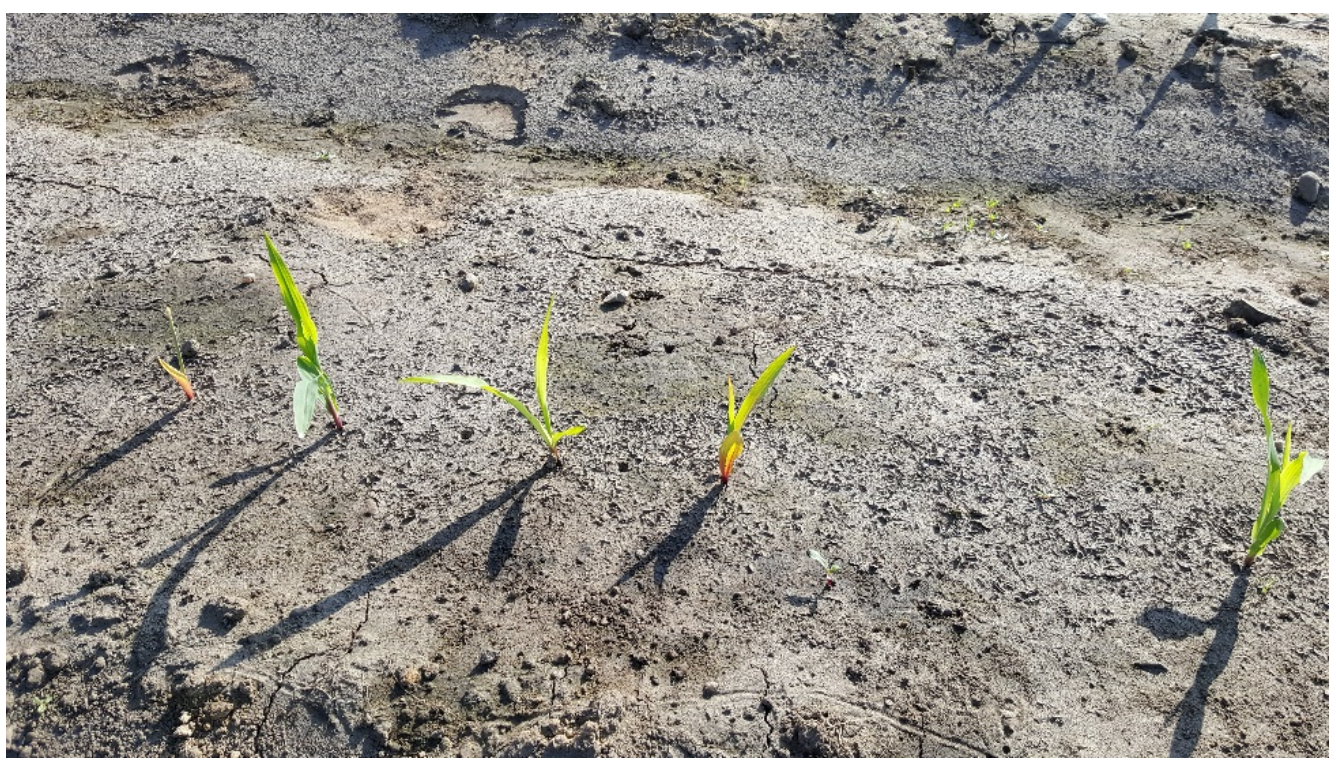

Figuur 13. Kiemplanten met het ziektebeeld

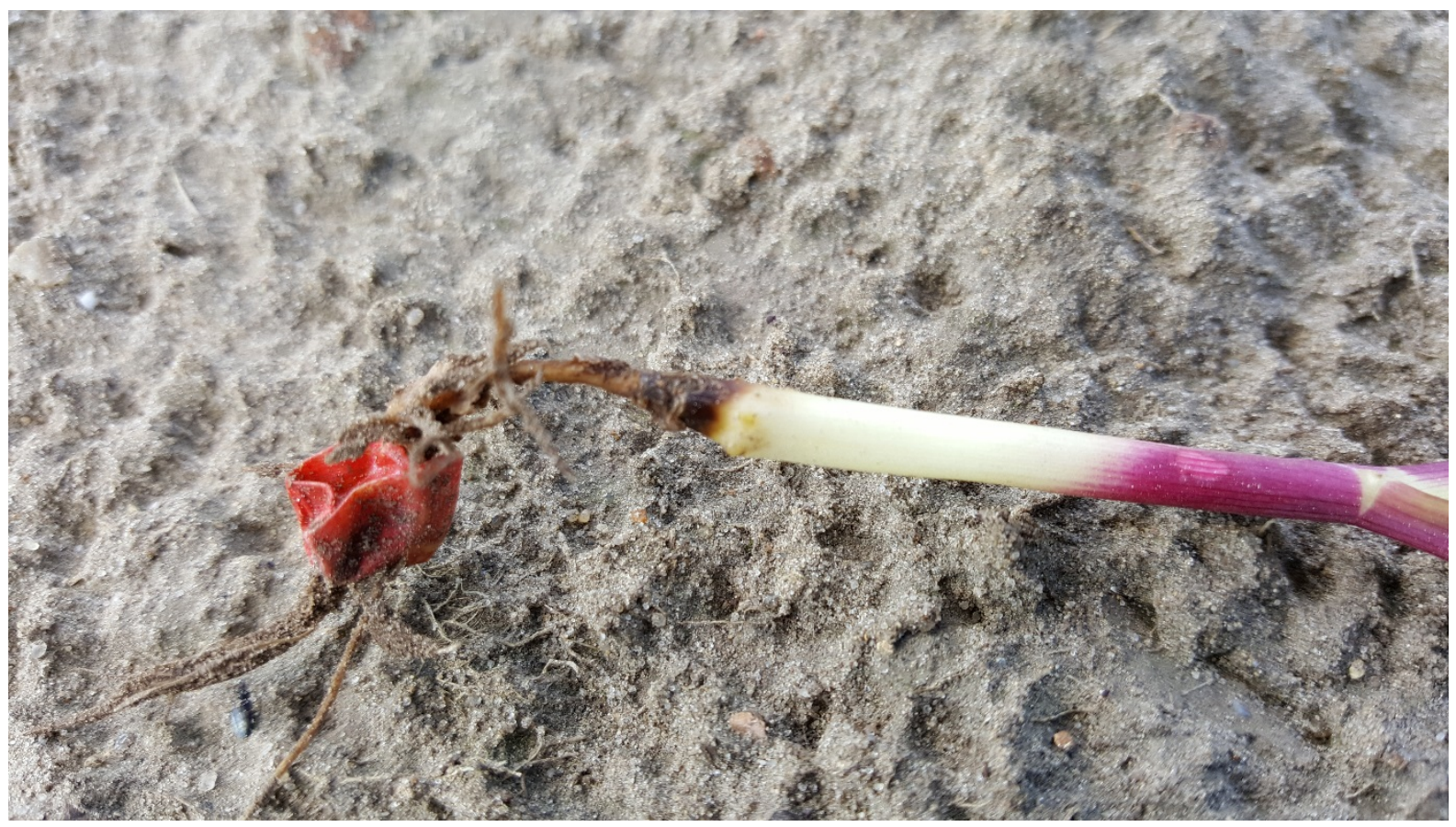

Figuur 14. Close-up van een aangetaste plant. De insnoering van de wortelhals rond het grondoppervlak is duidelijk zichtbaar. 


\subsubsection{Indringingsweerstand in de bodem}

In Figuur 15 is de indringingsweerstand in de bodem in het voorjaar van 2019 weergegeven. De indringingsweerstand is een maat voor de weerstand die een wortel ondervind maar het geeft ook aan of er sprake een verdichting is en op welke diepte deze voorkomt. De indringingsweerstand is per systeem weergegeven waarbij is gemeten tot een diepte van $40 \mathrm{~cm}$. Hieronder komt op locatie een keileemlaag voor en daarom is hier niet in gemeten. De gepresenteerde waardes zijn de gemiddelden van 10 metingen.

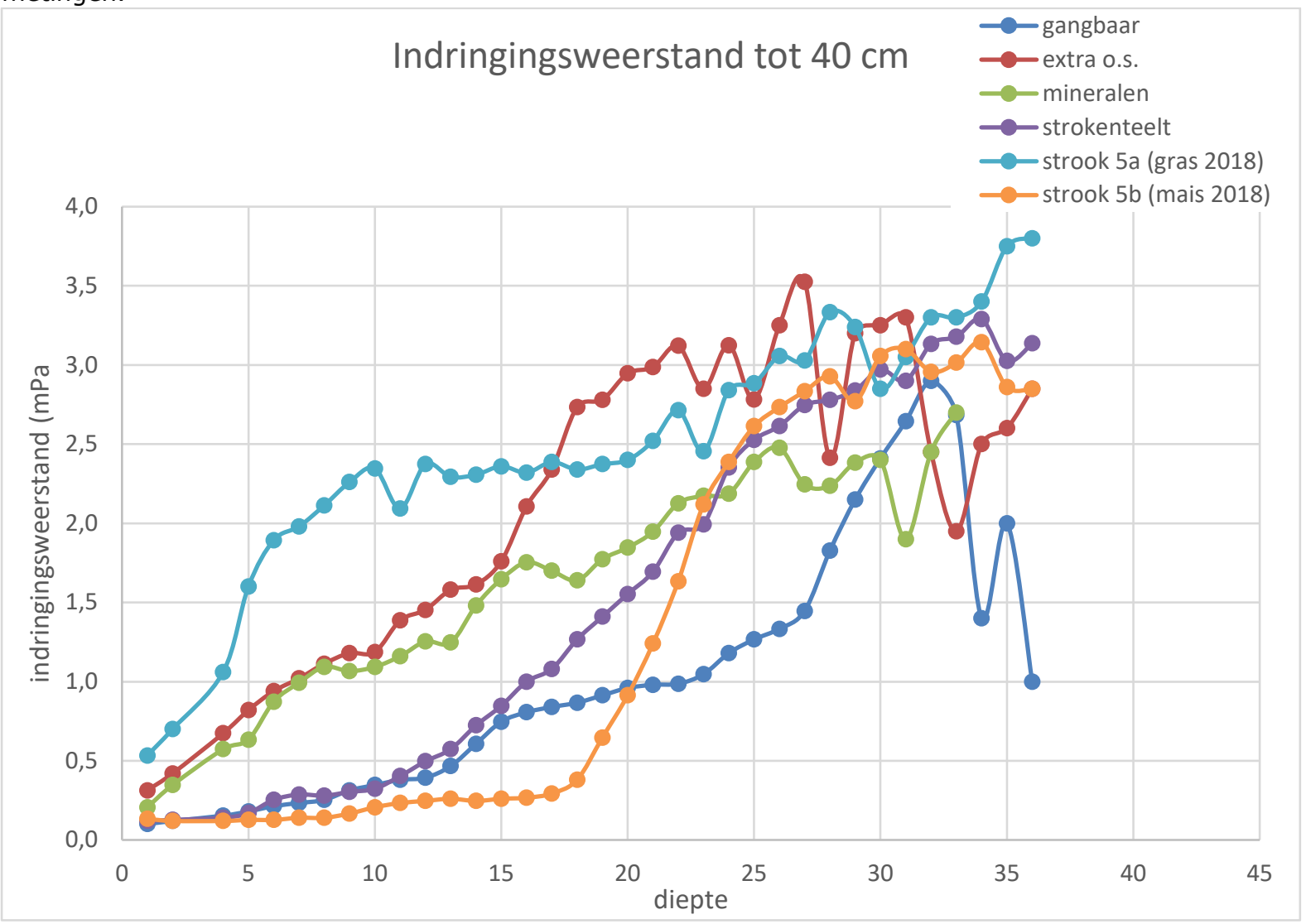

Figuur 15. Indringingsweerstand van de bodem onder de verschillende systemen gemeten in voorjaar 2019.

Uit de resultaten blijken een aantal verschillen tussen de systemen die grotendeels terug te leiden zijn op de manier van grondbewerken. Zo lijkt het object met 2-jarig gras (5a) een wat vastere ondergrond te bezitten. Dit is waarschijnlijk het gevolg van het niet bewerken van de grond in de afgelopen twee jaar dat er gras op heeft gestaan. Bij het organische stofsysteem is de bewerkingsdiepte tot circa $18 \mathrm{~cm}$ diepte beperkt, om te stimuleren dat er minder organische stof afbreekt. In vergelijking met het object met mineralen uit kringloop loopt de indringingsweerstand duidelijk op vanaf deze diepte.

In het standaard systeem is de indringingsweerstand relatief laag. Dit object is het enige uit de demonstratie dat wordt geploegd.

\subsubsection{Biomassa bepalingen vanggewas}

Om een indruk te krijgen hoeveel biomassa een vanggewas produceert, zijn op 21 maart 2019 de bovengrondse en ondergrondse hoeveelheden aan biomassa bepaald van de vanggewassen uit de systemendemonstratie. Om de bovengrondse biomassa te bepalen is een raamwerk van $0.25 \mathrm{~m} 2$ gebruikt (Figuur 16). De bovengrondse gewasdelen die binnen dit raamwerk zitten zijn afgesneden. De ondergrondse biomassa is bepaald door met een boor bodemmonsters te steken (Figuur 17). Zowel de bovengrondse als de ondergrondse metingen zijn op zes plaatsen uitgevoerd. Om de grond tussen de 
wortels te verwijderen, zijn de wortelresten schoon gespoeld. Vervolgens is van zowel de bovengrondse als de ondergrondse gewasdelen het versgewicht en het drogestofgehalte vastgesteld.

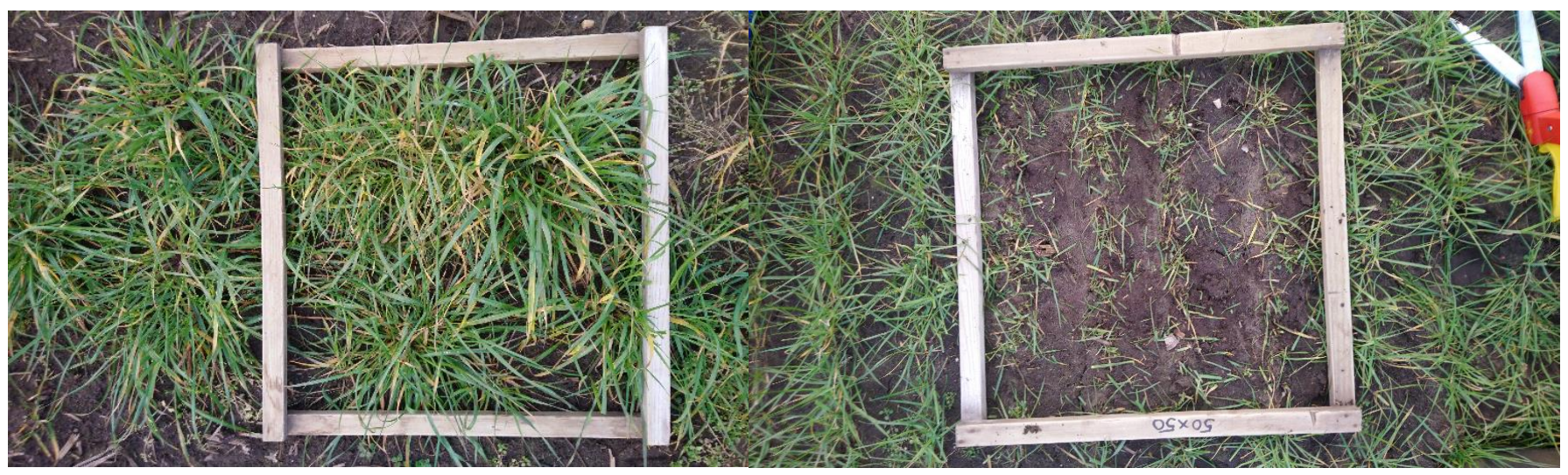

Figuur 16. Bepaling van de bovengrondse biomassa van vanggewassen.



Figuur 17. Verzamelen van ondergrondse biomassa door middel van een aardappelpootstok. 


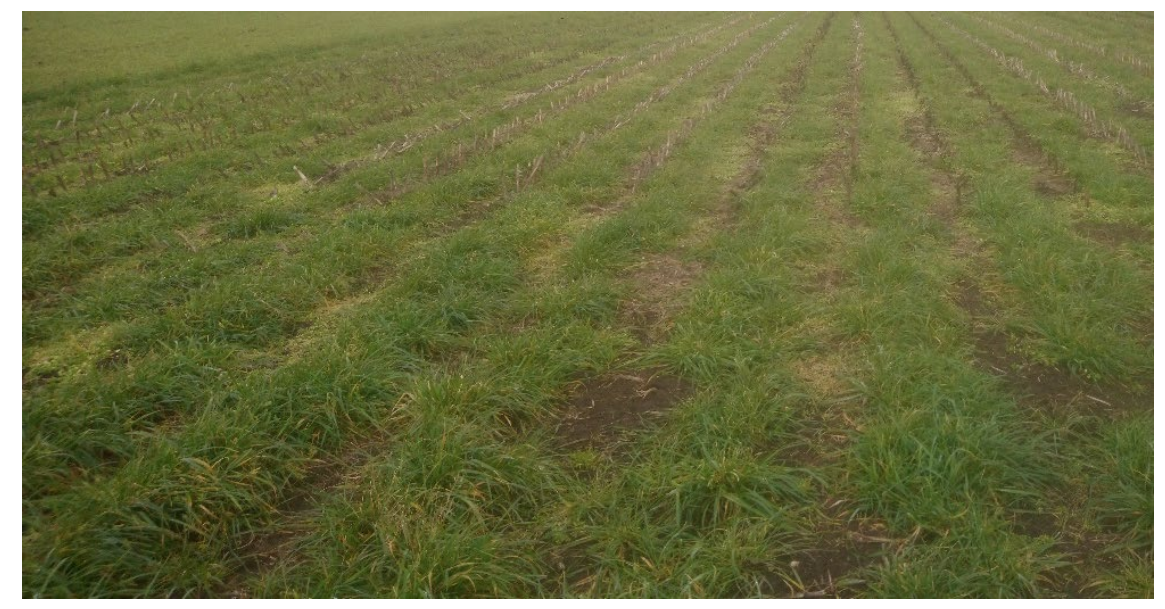

Figuur 18. Overzicht van ontwikkeld vanggewas in het voorjaar van 2019

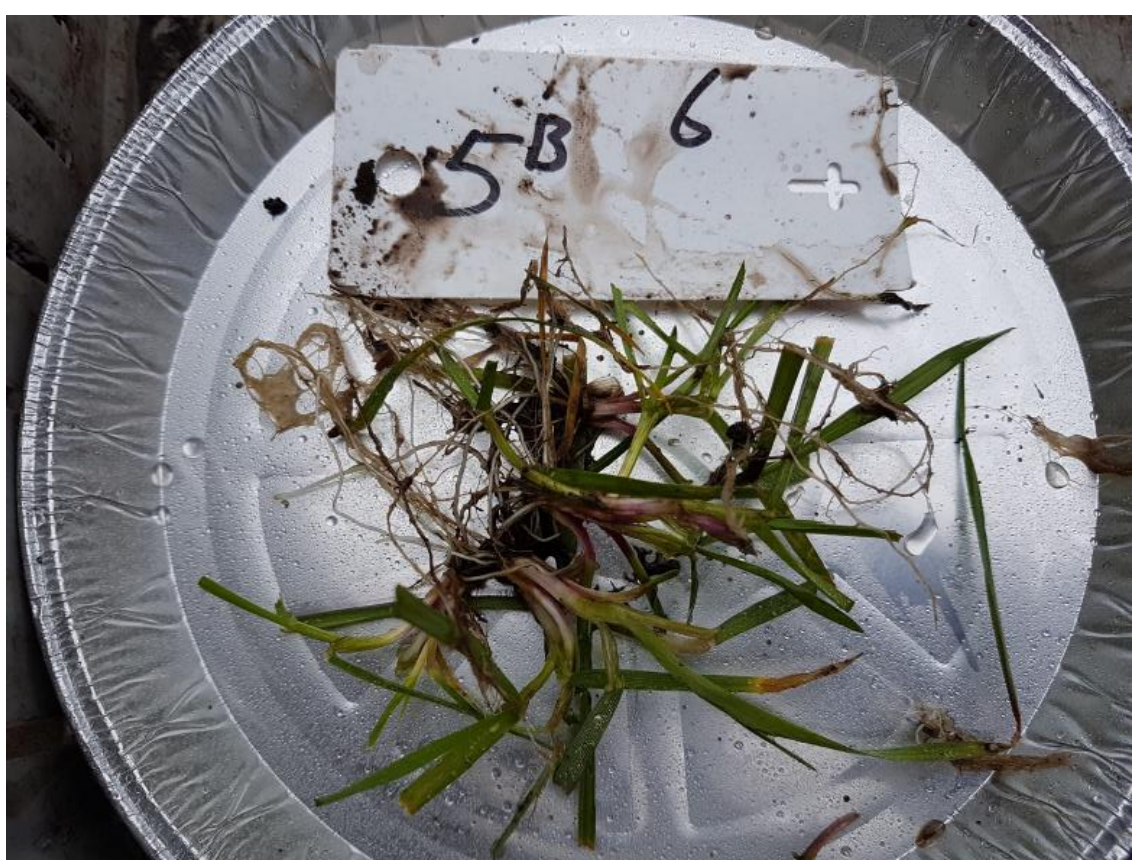

Figuur 19. De biomassa na het spoelen.

Tabel 9. Onder- en bovengrondse biomassa (vers en droog) van de vanggewassen uit de verschillende maissystemen.

\begin{tabular}{lrcrrr}
\hline & \multicolumn{2}{c}{ bovengronds (ton/ha) } & \multicolumn{2}{c}{ ondergronds (ton/ha) } & \multicolumn{2}{c}{ ton/ha } \\
Systeem & vers & Droge stof & vers & Droge stof & totaal droge stof \\
\hline gangbaar & 6.6 & 2.1 & 21.7 & 4.3 & 6.4 \\
extra organische stof & 5.7 & 1.4 & 47.7 & 7.8 & 9.2 \\
mineralen & 11.5 & 2.8 & 35.1 & 6.5 & 9.3 \\
strokenteelt & 2.5 & 0.6 & 25.1 & 3.9 & 4.5 \\
strokenteelt & 2.6 & 0.7 & 11.7 & 2.2 & 2.8 \\
2 jarig gras & 6.2 & 1.5 & 52.4 & 15.6 & 17.1 \\
herinzaai gras & 1.0 & 0.3 & 9.5 & 1.7 & 2.0 \\
\hline
\end{tabular}


Uit Tabel 9 blijkt dat er duidelijke verschillen in droge stofproductie zijn waargenomen tussen de verschillende systemen. Veruit de grootste hoeveelheid biomassa werd gevonden in het 2-jarige gras waarvan het merendeel ondergronds zat. Tussen de systemen gangbaar, extra organische stof en het mineralensysteem waren de verschillen minder groot, terwijl er in systeem gangbaar rogge is nagezaaid en in het organische stof en mineralensysteem gras is ondergezaaid. Bij het object met strokenteelt is opnieuw gras ingezaaid. Omdat er na de oogst van de mais opnieuw gras is ingezaaid, heeft zich hier nog nauwelijks gras weten te ontwikkelen.

\subsection{Detaildemonstraties}

\subsubsection{Detaildemonstratie onderzaai en gewasbescherming}

In de detaildemo onkruidbeheersing zijn verschillende bestrijdingstechnieken beproefd. De detaildemo in 2018 is aangelegd onder gunstige omstandigheden qua vocht en temperatuur. De mais kende een vlotte weggroei. Het effect van de verschillende toepassingen is getoetst in combinatie met onderzaai van rietzwenkgras in het 2 bladstadium en onderzaai met Italiaans Raaigras in het 6 bladstadium. Het behandelingsoverzicht is weergeven in Tabel 10. Het eggen in op 30 mei en 5 juni uitgevoerd. De bespuitingen zijn eveneens op 30 mei en 5 juni uitgevoerd.

Tabel 10. Behandelingsoverzicht van de detaildemo onderzaai en gewasbescherming

\begin{tabular}{|c|c|c|c|c|c|c|}
\hline & Objecten & 3 dgn na zaai & 5-10 dgn na zaai & 2-bladstadium & 6-bladstadium & \\
\hline \multirow{8}{*}{$\begin{array}{l}\text { A. } \\
\text { B. } \\
\text { C. } \\
\text { D. } \\
\text { E. } \\
\text { G. } \\
\text { F. } \\
\text { H }\end{array}$} & \multirow{8}{*}{$\begin{array}{l}\text { Mechanisch } \\
\text { Mechanisch+ chemisch } \\
\text { Gangbaar chemisch } \\
\text { Alleen contactherbiciden } \\
\text { LDS contact+bodem } \\
\text { bodemherb + LDS contact } \\
\text { bodemherb + LDS contact } \\
\text { Alleen contactherbiciden II }\end{array}$} & \multirow{8}{*}{$80 \mathrm{~g}$} & \multirow{8}{*}{$\begin{array}{l}1-2 x \text { eggen } \\
1-2 x \text { eggen }\end{array}$} & \multirow{8}{*}{$\begin{array}{l}\text { schoffelen + licht aanaarden } \\
\text { schoffelen + licht aanaarden } \\
\text { 1.0 Frontier+0.75 Milagro+1.5 Calaris } \\
0.75 \text { Milagro + } 1.5 \text { Calaris } \\
0.3 \text { Milagro + } 0.3 \text { Calaris } \\
0.4 \text { Milagro + } 0.5 \text { Calaris + } 0.5 \text { Kart* } \\
0.4 \text { Milagro + } 0.5 \text { Calaris + } 0.5 \text { Kart* } \\
\text { 2.0 Laudis + 0.75 Milagro }\end{array}$} & \multirow{8}{*}{$\begin{array}{l}\text { schoffelen + aanaarden } \\
0.5 \text { Laudis+0.5 Gardo }\end{array}$} & 30-mei en 5 juni eggen \\
\hline & & & & & & 30 mei en 5 juni gespoten \\
\hline & & & & & & 30 mei en 5 juni gespoten \\
\hline & & & & & & 30 mei en 5 juni gespoten \\
\hline & & & & & & 30 mei en 5 juni gespoten \\
\hline & & & & & & 30 mei en 5 juni gespoten \\
\hline & & & & & & 30 mei en 5 juni gespoten \\
\hline & & & & & & 5-jun \\
\hline
\end{tabular}

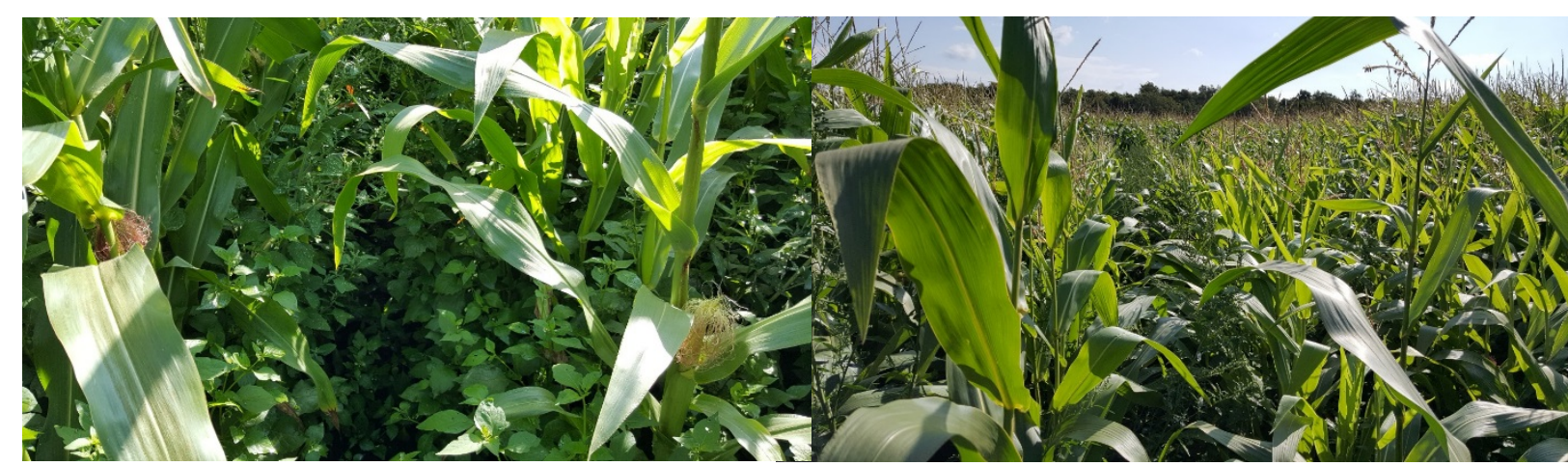

A Enkel mechanische onkruidbestrijding 

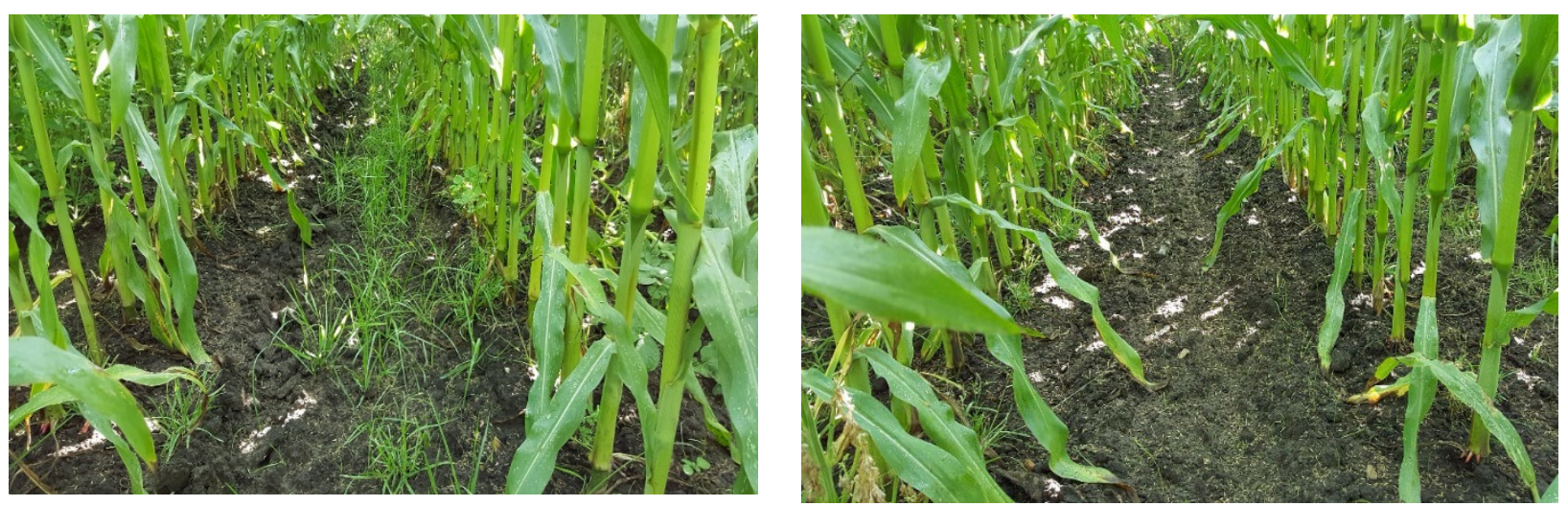

B Mechanisch + Chemisch. Links rietzwenk, rechts Italiaans

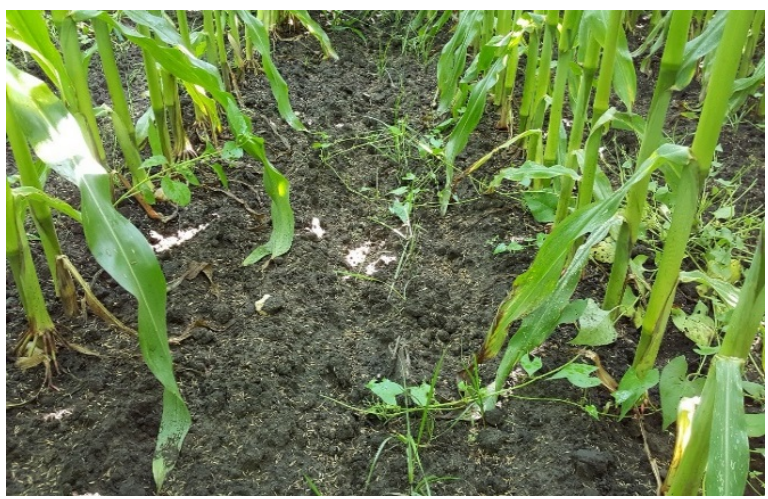

C Gangbaar chemisch

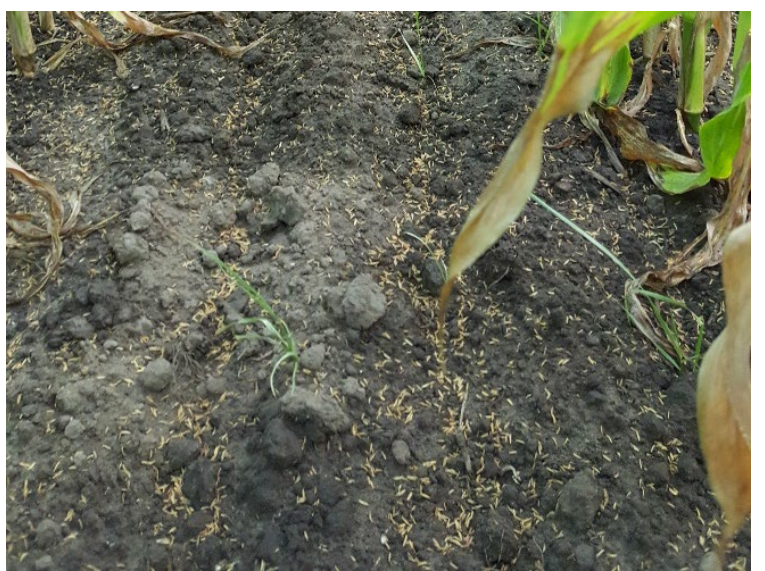

Object E: LDS contact + bodem

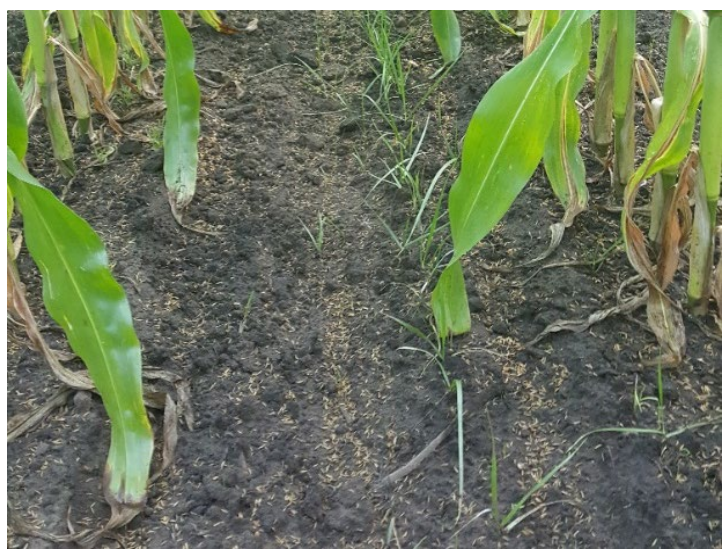

G bodemherbicide + LDS contact

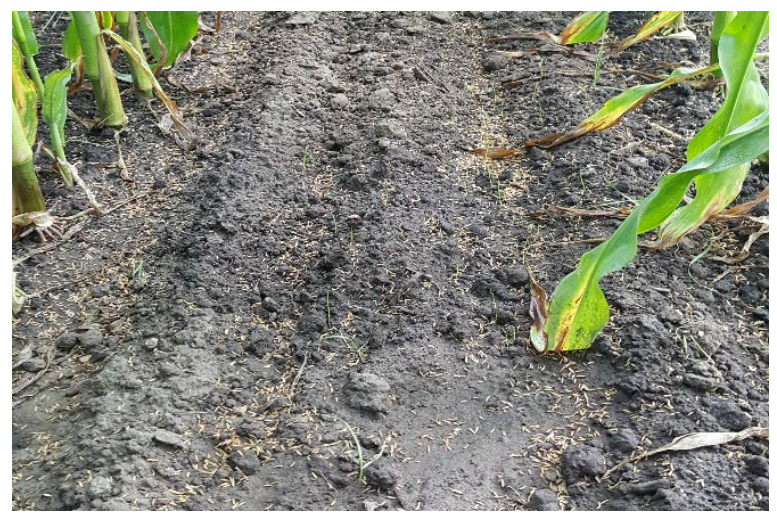

D enkel contact

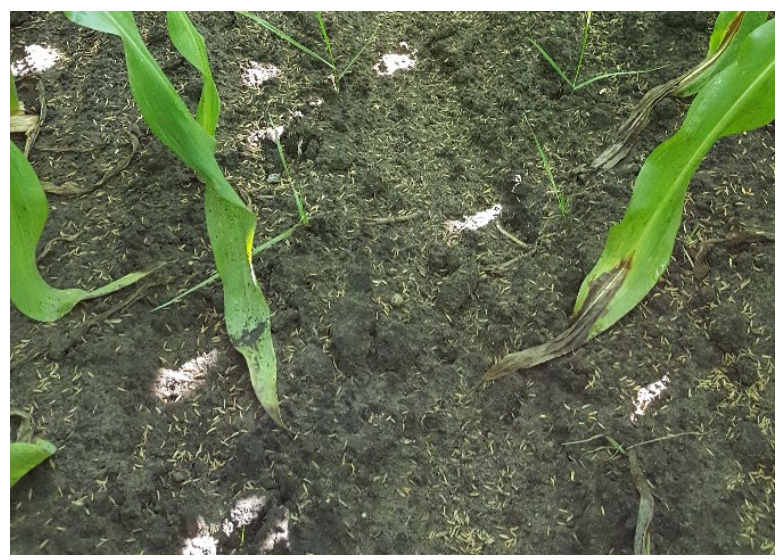

F bodemherbicide + LDS contact

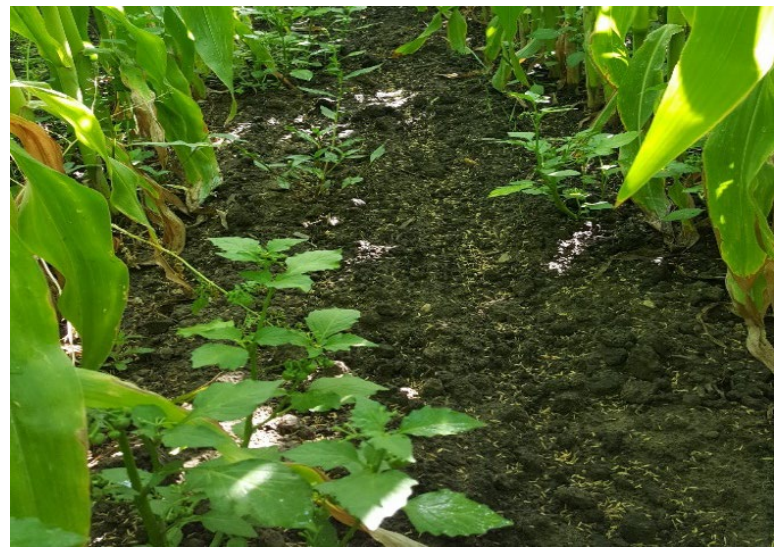

H Enkel contact 
De mechanische onkruidbestrijding was in deze demo ontoereikend. Het object gangbaar chemisch (C) toonde het laagste aantal raaigras planten bij een beoordeling op 10 augustus, waarschijnlijk door de werking van de bodemherbicide. Toch leek het erop dat een deel van het zaad later nog uitliep. Onderling tussen de objecten $\mathrm{D} \mathrm{t} / \mathrm{m} \mathrm{H}$ werden geen eenduidige visuele verschillen vastgesteld qua slaging van de onderzaai. In object $\mathrm{H}$ werden nakiemers van nachtschade gevonden. Over het algemeen moet worden gesteld dat object B een betere ontwikkeling van de grassen had.

\subsubsection{Demonstratie alternatieve onderzaaigewassen}

In deze detaildemo zijn verschillende typen onderzaai getoetst. In de demo is ondergezaaid met Italiaans raaigras, rode klaver, Perzische klaver en Italiaans raaigras + rode klaver. De combinaties van onderzaai zijn getoetst bij het ras LG 31211 en Asgaard. Asgaard is een vroeger ras dan LG 31211. Asgaard laat vanwege een minder forse loofontwikkeling en een iets andere bladstand meer zonlicht door tot de bodem. Dankzij deze 'openere' bladstand krijgt de onderzaai meer ruimte tot groeien onder de mais. De onkruidbestrijding is uitgevoerd op $31 \mathrm{mei}$, zonder bodemherbicide. Er is 12 juni ondergezaaid. De proefopzet en de toegepaste zaaizaadhoeveelheden is weergegeven in Figuur 20.

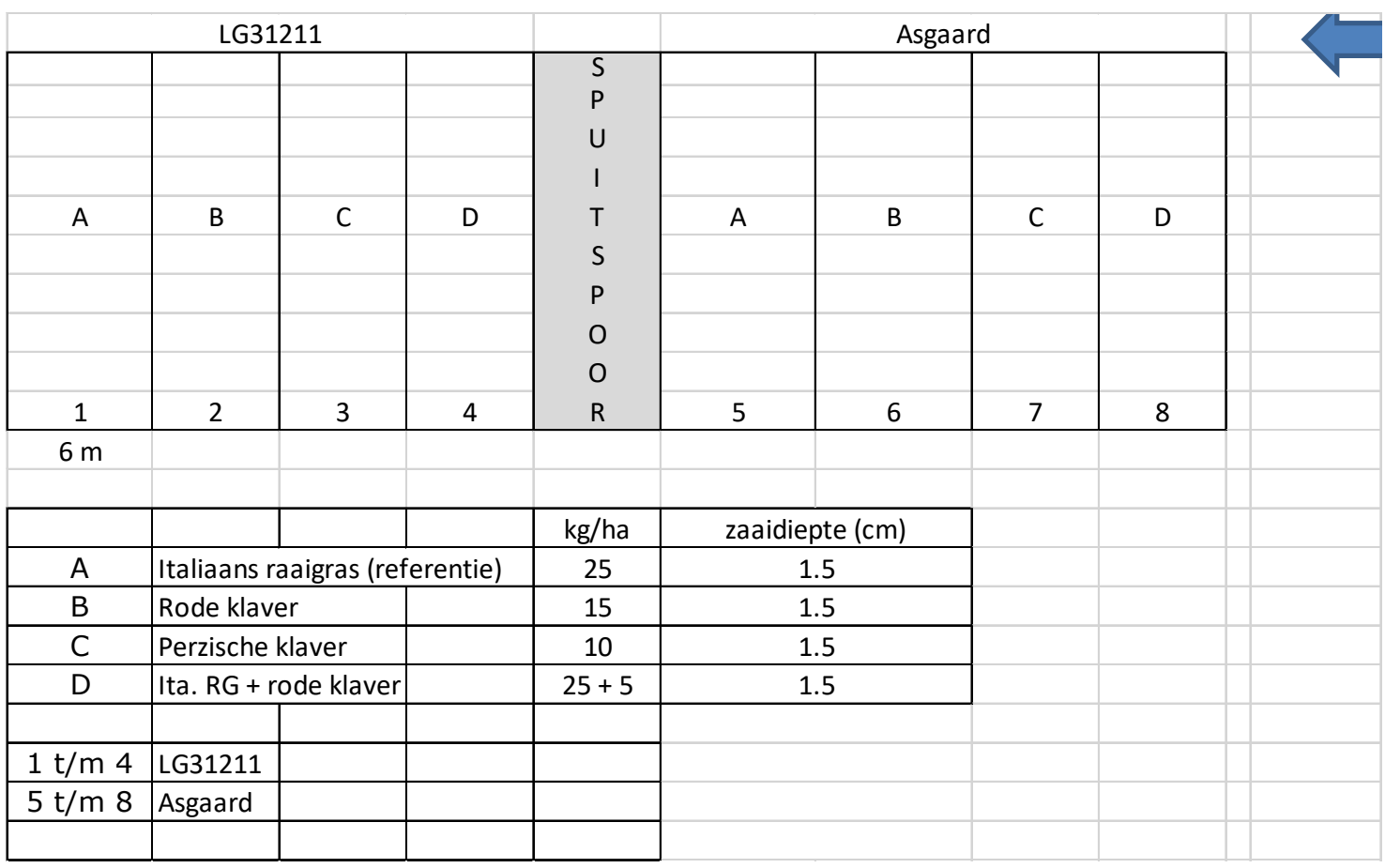

Figuur 20. Schematisch overzicht van detaildemo Alternatieve onderzaaigewassen.

Tijdens het seizoen was er weinig verschil zichtbaar tussen beide maisrassen qua bladontwikkeling. De proef is vanwege de droogte twee maal beregend. Er waren geen eenduidige effecten zichtbaar van het ras op de ontwikkeling van de onderzaai. Over het algemeen was de ontwikkeling van klavers matig tot slecht. Op de foto's hieronder een impressie van de ontwikkeling van de onderzaai. Foto's zijn genomen op 13 augustus. 


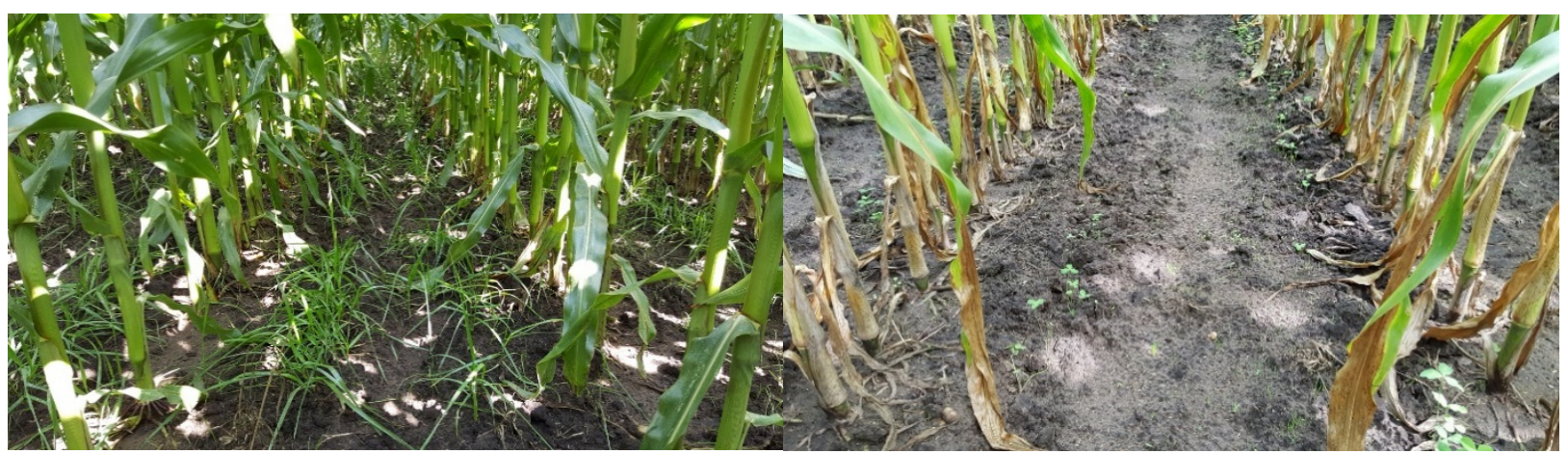

Object A: Italiaans raaigras

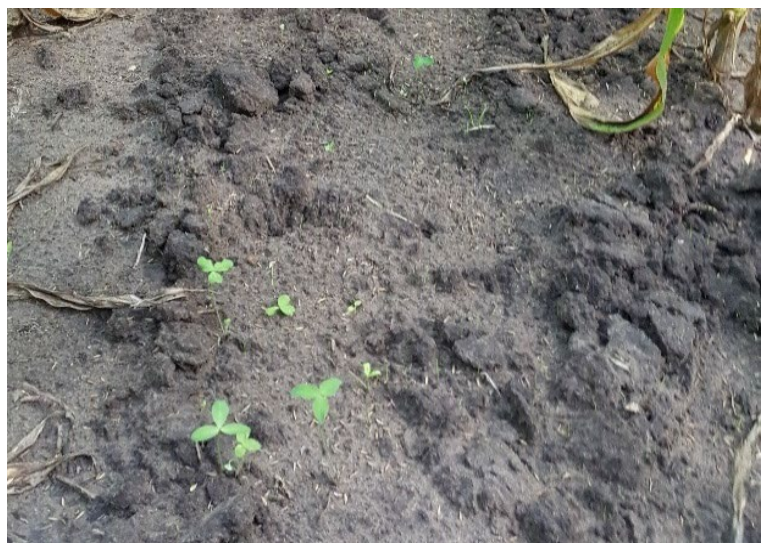

Object B: Rode klavers (close-up)
Object B: Rode klavers

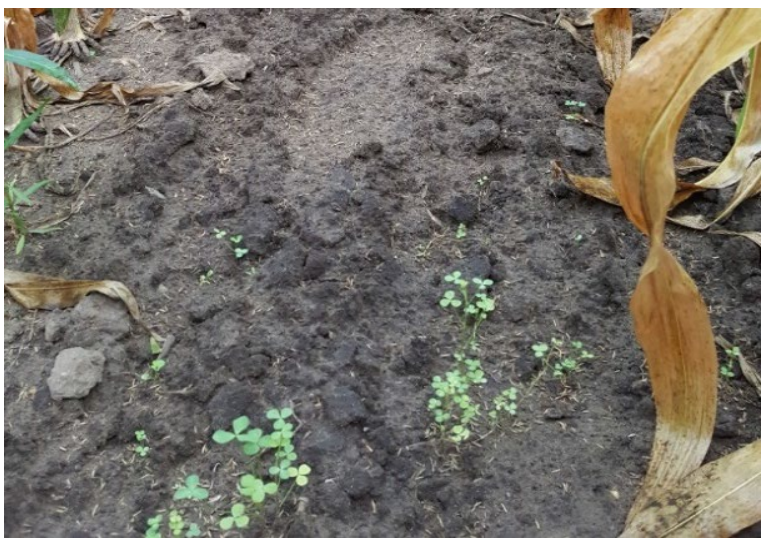

Object C: Perzische klaver (close-up)

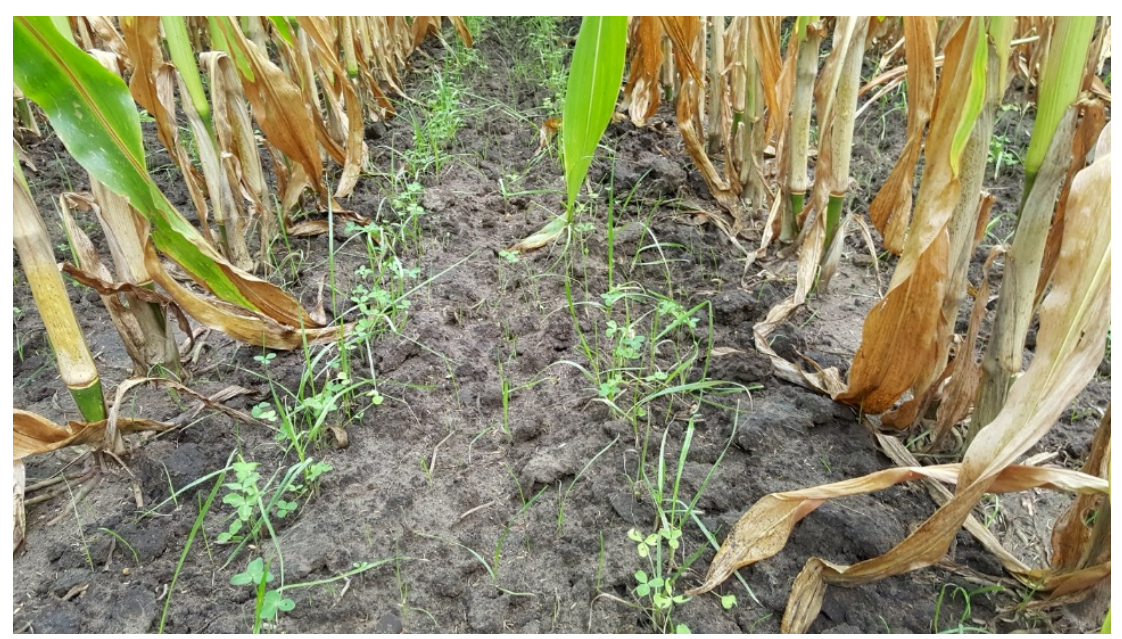

Object D: Grasklaver

Conclusies:

De groei en ontwikkeling van klavers was minimaal. In het object waar klaver werd gecombineerd met gras (D) was de klaver beter ontwikkeld. Het tegenvallen van de klavers kan te wijten zijn aan de droogte. Wel is de demo twee maal beregend. Verder ligt de $\mathrm{pH}$-waarde op het perceel rond de $\mathrm{pH} \mathrm{KCl}$ 5.0. mogelijk dat ook deze een rol speelt. 


\subsubsection{Inwerken van groenbemester}

In de detaildemo 'inwerken groenbemester' is gezocht naar alternatieven om een geslaagde onderzaai met Italiaans raaigras onder te werken zonder inzet van glyfosaat. In de demo is een goed geslaagde onderzaai met verschillende mechanische bewerkingen aangepakt. In de detaildemo is het vergelijk gemaakt tussen wel of niet klepelen, het wel niet frezen. Bij het klaarleggen van het zaaibed is het vergelijk gemaakt tussen een smaragd+vorenpakker en de spitmachine+vorenpakker.

Tabel 11. Overzicht van de verschillende objecten in de inwerkdemo.

\begin{tabular}{|l|l|l|l|l|}
\hline & \multicolumn{1}{|c|}{ A } & \multicolumn{1}{c|}{ B } & \multicolumn{1}{c|}{ C } \\
\hline half april & foto & foto & foto & foto \\
\hline begin april & frezen & & frezen & \\
\hline eind april & $\begin{array}{l}\text { smaragd + } \\
\text { zaaiklaar }\end{array}$ & $\begin{array}{l}\text { smaragd + } \\
\text { zaaiklaar }\end{array}$ & $\begin{array}{l}\text { spitten + } \\
\text { vorenpakker }\end{array}$ & $\begin{array}{l}\text { spitten + } \\
\text { vorenpakker }\end{array}$ \\
\hline ca. 1 mei & maïs zaaien & maïs zaaien & maïs zaaien & maïs zaaien \\
\hline ca. 1 mei & foto & foto & foto & foto \\
\hline maïs 2-blad & Milagro & Milagro & Milagro & Milagro \\
\hline maïs 2-blad & foto & foto & foto & foto \\
\hline half juni & gras onderzaai & gras onderzaai & gras onderzaai & gras onderzaai \\
\hline
\end{tabular}

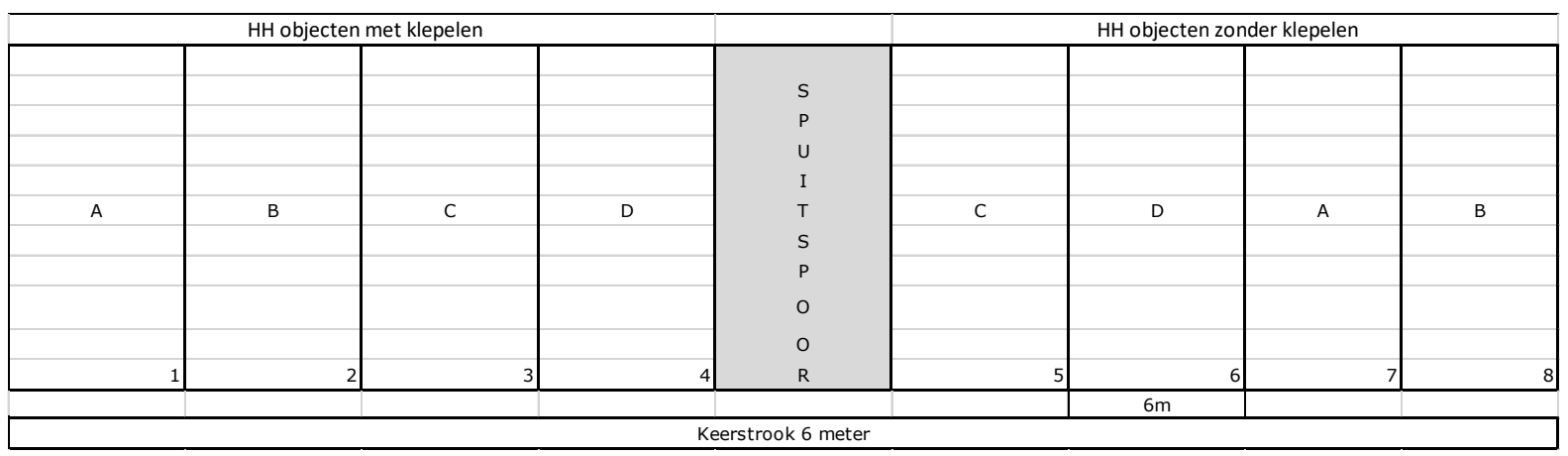

Figuur 21. Schematisch overzicht van de demo in het veld.

De behandelingen zijn aangelegd in tweevoud. Eenmaal met en eenmaal zonder te klepelen. Vervolgens zijn objecten $A$ en $C$ gefreesd en is het zaaibed klaargelegd met de smaragd met vorenpakker. De resterende veldjes zijn zaaiklaar gelegd met de spitmachine met vorenpakker. Teven is van elk object de helft gespoten met Milagro/ Samson. 

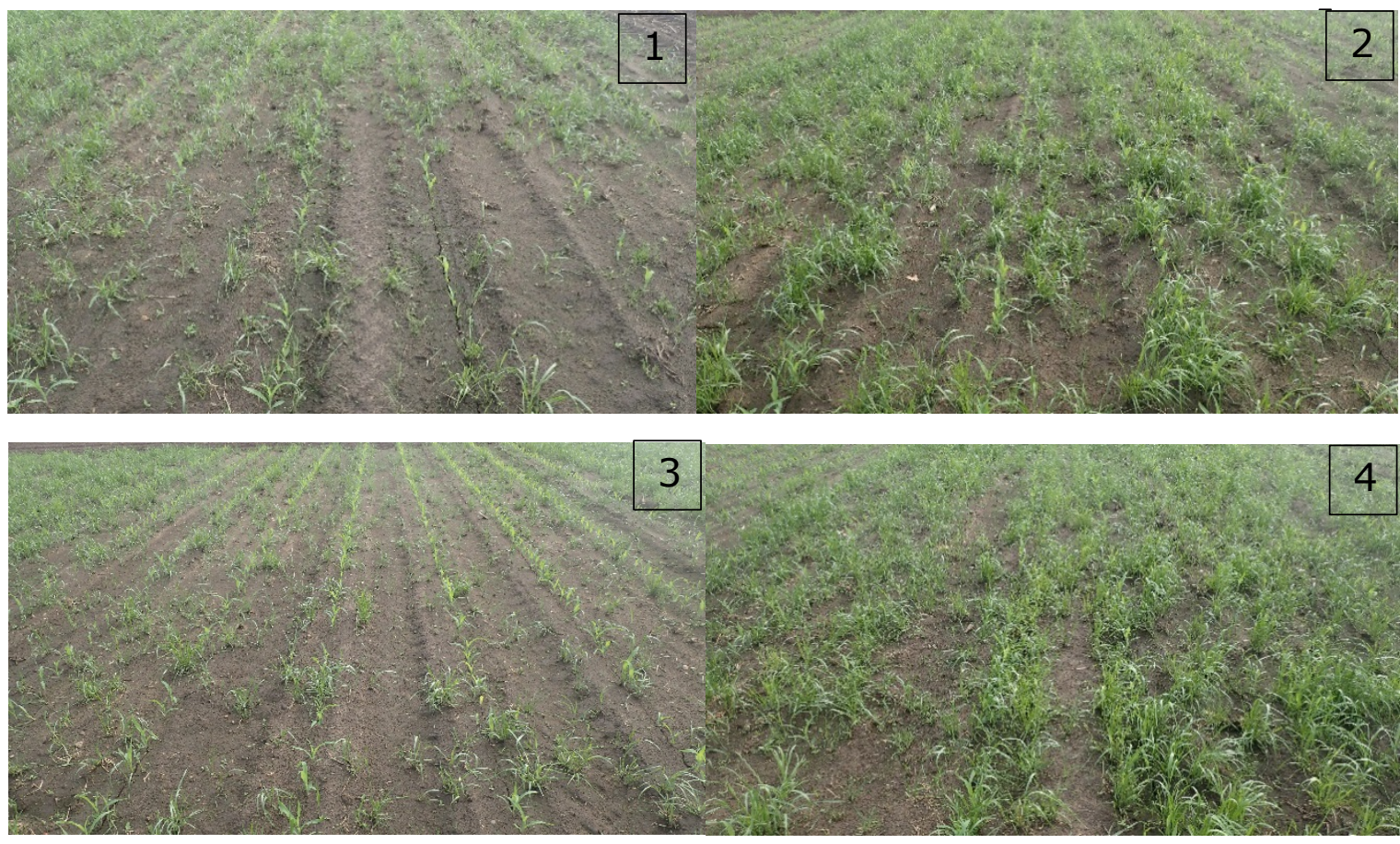

Figuur 22. De objecten van de demo met voorbehandeling klepelen. $1=A, 2=B, 3=C, 4=D$. Stand op 23 mei.

Objecten 1 en 3 tonen dat met het frezen een fors mindere hoeveelheid gras uitliep, zie Figuur 22. Bij de objecten 2 en 4 is zichtbaar dat er grovere graspollen aanwezig waren. Het patroon voor de objecten 5 $\mathrm{t} / \mathrm{m} 8$ (zonder klepelen) was nagenoeg hetzelfde.

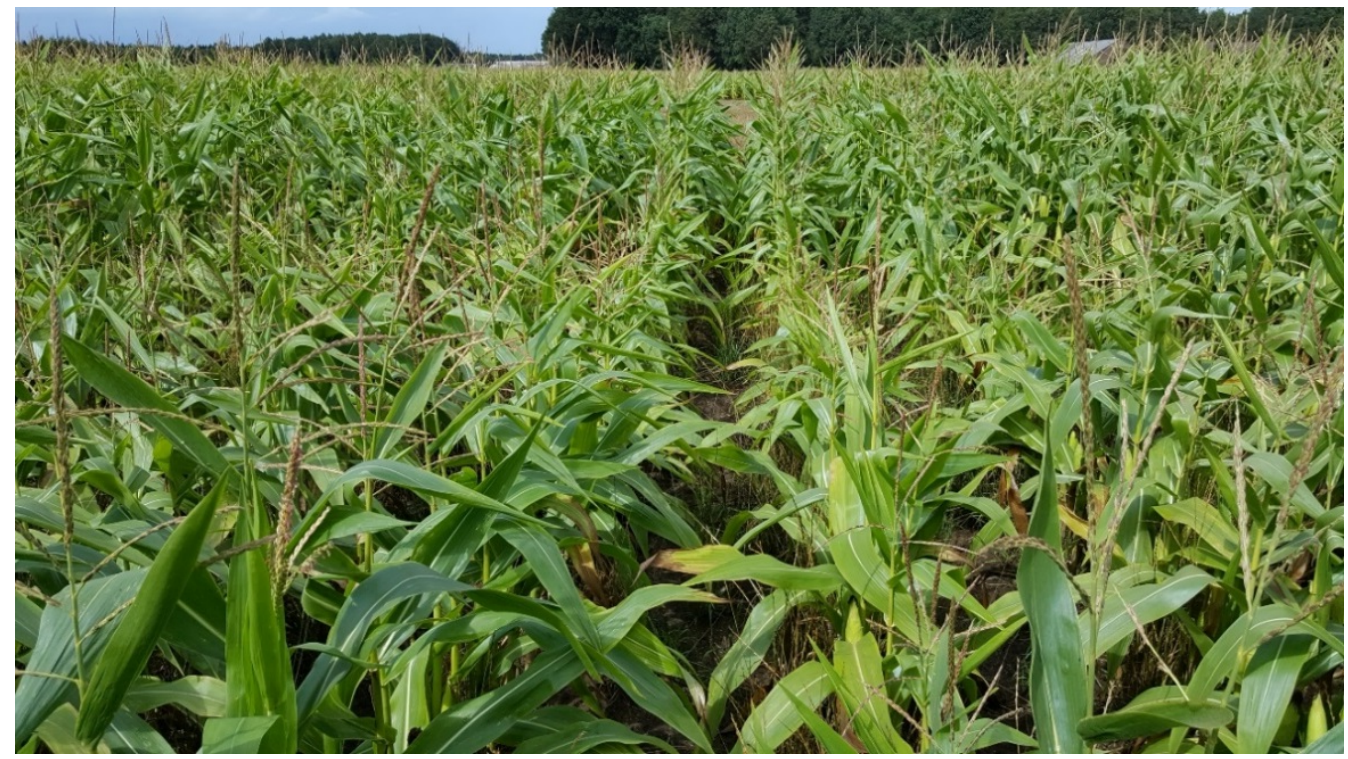

Figuur 23. Object A1, klepelen, frezen en zaaibed klaarleggen met smaragd. In de voorgrond deel dat niet gespoten is met Samson/Milagro, in de achtergrond wel gespoten deel.

In Figuur 23 is te zien dat wanneer er niet gespoten is met Samson/Milagro, de mais concurrentie ondervindt van het achtergebleven gras. 
Conclusies:

In de detaildemo is gekeken naar een voorbewerking door middel van klepelen. Het klepelen bleek nauwelijks van invloed te zijn op het eindresultaat. De frees bleek in staat om het gras te verkleinen zonder dat de bovengrondse delen verkort hoefden te worden. Het frezen van de zode had een sterker effect op het vernietigen van de zode dan de smaragd. Bij het frezen werd het gras als het ware van de wortel afgesneden. Bovendien resulteerde het frezen in fijnere polletjes dan bij de smaragd. Bij een smaragdbewerking zonder frezen vooraf was de hergroei groter omdat er grotere pollen achterbleven. Het nadeel van frezen is dat het een trage en daardoor kostbare bewerking is. De effecten van spitten op het vanggewas waren vergelijkbaar met die van de smaragd. 


\section{$4 \quad$ Satellietbedrijven}

\subsection{Graveland}

Het bedrijf van Wout Graveland telt circa 100 melkkoeien en 65 stuks jongvee. De totale oppervlakte is 64 ha waarvan 13 ha mais. Het bedrijf is gelegen op zandgrond en wat ruwvoer betreft zelfvoorzienend.

\subsubsection{Huidige methode maïsteelt}

De hoofdgrondbewerking bij de maisteelt bestaat uit ploegen. Voorafgaand aan het ploegen wordt 45 $\mathrm{m}^{3} / \mathrm{ha}$ runderdrijfmest toegediend middels bouwlaninjectie. Daarnaast wordt bij zaaien $35-40 \mathrm{~kg}$ stikstof in de rij gegeven en na het zaaien wordt tegenwoordig ca $60 \mathrm{~kg} \mathrm{~K} \mathrm{~K}_{2} \mathrm{O}$ in de vorm van kali60 breedwerpig gestrooid. De oogst van de mais vindt meestal half oktober plaats.

Team: Wout Graveland, Jan Oetsen (voorzitter studieclub Koekange), Herman van Schooten (Wageningen Livestock Research)

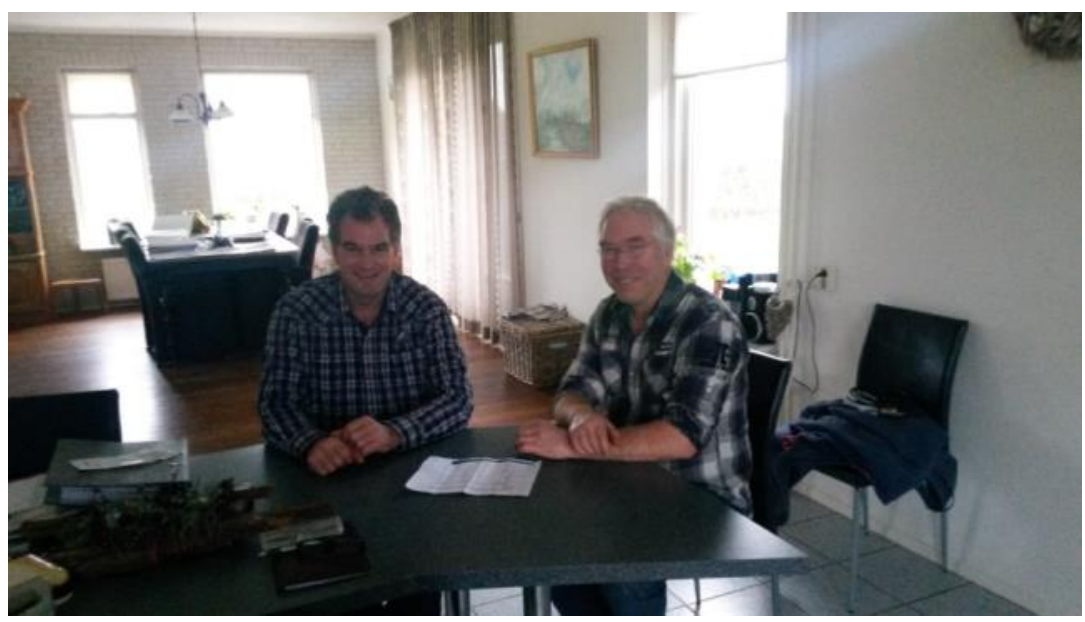

Figuur 24. Links Wout Graveland en rechts Jan Oetsen

\subsubsection{Plan van aanpak}

\subsubsection{Effect grondbewerking op organische stofgehalte bodem met Verisscan}

In maart 2015 is voorafgaand aan de aanleg van het demoperceel het perceel gescanned met de verisscan. Om na drie jaar het effect van de beide verschillende grondbewerkingen (ploegen en strokenteelt) op het gehalte aan organische stof te monitoren is het demoperceel dit voorjaar weer gescanned.

De verisscan is een apparaat dat is gekoppeld aan een trekker en scant via een woelpoot en schijven met o.a. NIRS om de 10 meter de bodem. Het bepaalt de $\mathrm{pH}$, OS en elektrische geleidbaarheid (EC). Vanuit de scan kan vervolgens een zogenaamde taakkaart gemaakt worden die aangeeft waar de gehaltes hoog of laag zijn. Op basis van deze gegevens kan vervolgens specifiek bemest of bekalkt worden.

\subsubsection{Zaaimethoden/bemesting}

Dit jaar zijn de drie hoofdbehandelingen (Traditioneel bouwlandinjectie, Drijfmestrijenbemesting en Strokenteelt) op dezelfde perceelsdelen aangelegd als in 2015 t/m 2017 (zie Figuur 12). De behandeling 
Strokenteelt is opgedeeld in een deel waarbij de drijfmestbemesting is aangevuld met Maismap en een deel waarbij die is aangevuld met KAS. Samengevat zijn de volgende behandelingen aangelegd:

1. Traditioneel bouwlandinjectie: ploegen $+45 \mathrm{~m}^{3} / \mathrm{ha}$ RDM bouwlandinjectie plus $160 \mathrm{~kg} / \mathrm{ha}$ Maismap $25 \mathrm{~N}+10 \% \mathrm{SO} 3+\mathrm{B}$ rijenbemesting bij zaaien

2. Drijfmestrijenbemesting: Ploegen + drijfmestrijenbemesting $35 \mathrm{~m}^{3} / \mathrm{ha}$ RDM plus $160 \mathrm{~kg} / \mathrm{ha}$ Maismap $25 \mathrm{~N}+10 \% \mathrm{SO} 3+\mathrm{B}$ rijenbemesting bij zaaien, zie Figuur 13

3. Strokenteelt: zie Figuur 14

a. Met maismap: $45 \mathrm{~m}^{3} /$ ha RDM met zodenbemester, daarna strokenfrezen en zaaien aangevuld met $200 \mathrm{~kg}$ Maismap $25 \mathrm{~N}+10 \mathrm{SO} 3+\mathrm{B}$ breedwerpig

b. Met KAS: $45 \mathrm{~m}^{3} \mathrm{RDM}$ per ha met zodenbemester, daarna strokenfrezen en zaaien aangevuld met $200 \mathrm{~kg}$ KAS Zwavel $24 \mathrm{~N}+14 \mathrm{SO} 3$ breedwerpig

De bemesting is op het hele perceel aangevuld met $125 \mathrm{~kg} / \mathrm{ha}$ Kali60

\subsubsection{Varianten vanggewas}

1. Onderzaai van Italiaans raaigras bij vroeg maisras (LG 30.215) i.c.m. met twee grondbewerkingen

a. Niet kerende grondbewerking

b. Ploegen

2. Nazaai van Italiaans raaigras of rogge bij zeer vroeg maisras (Autens)

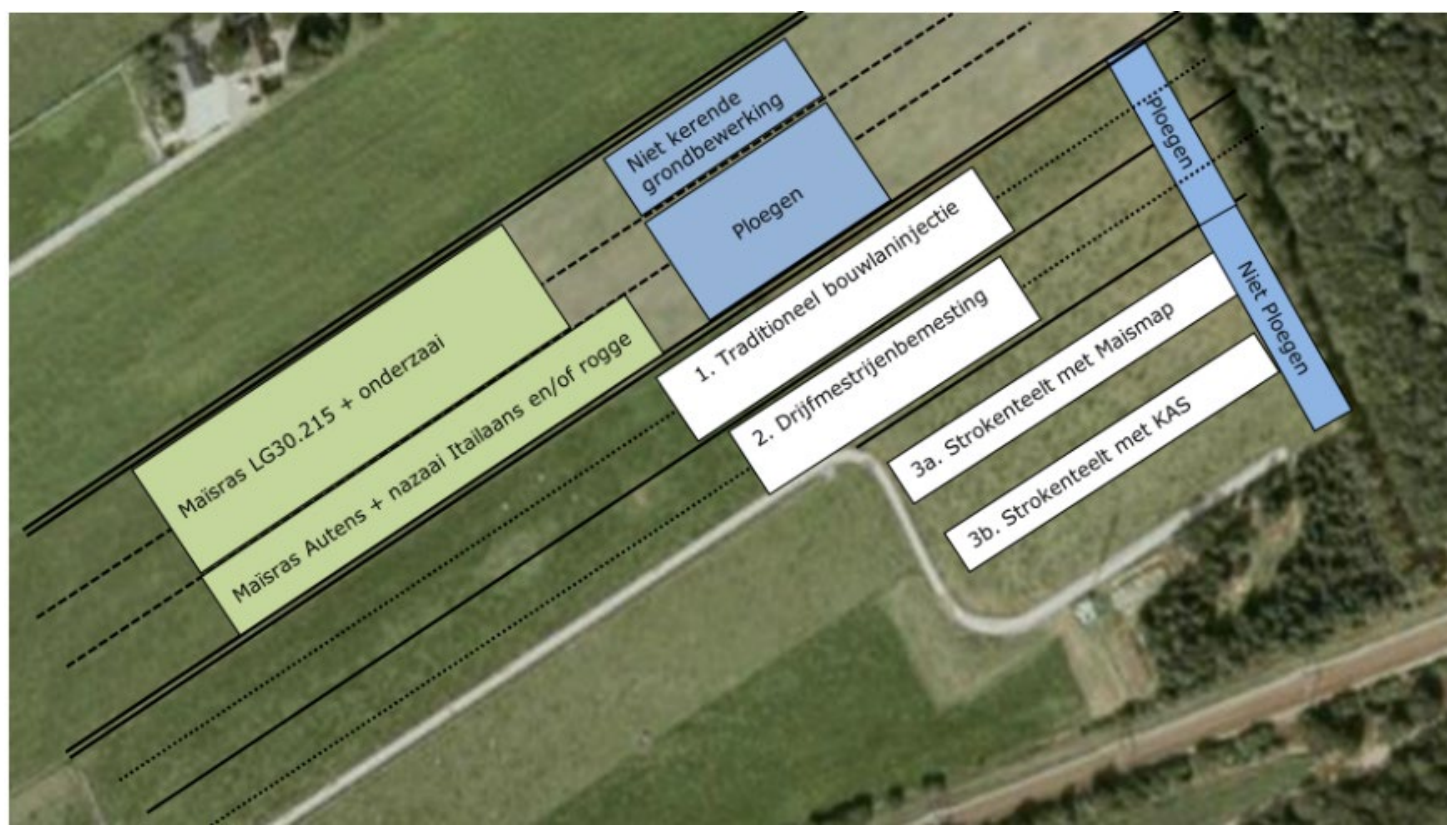

Figuur 25. Schematisch overzicht van het demoperceel van Wout Graveland.
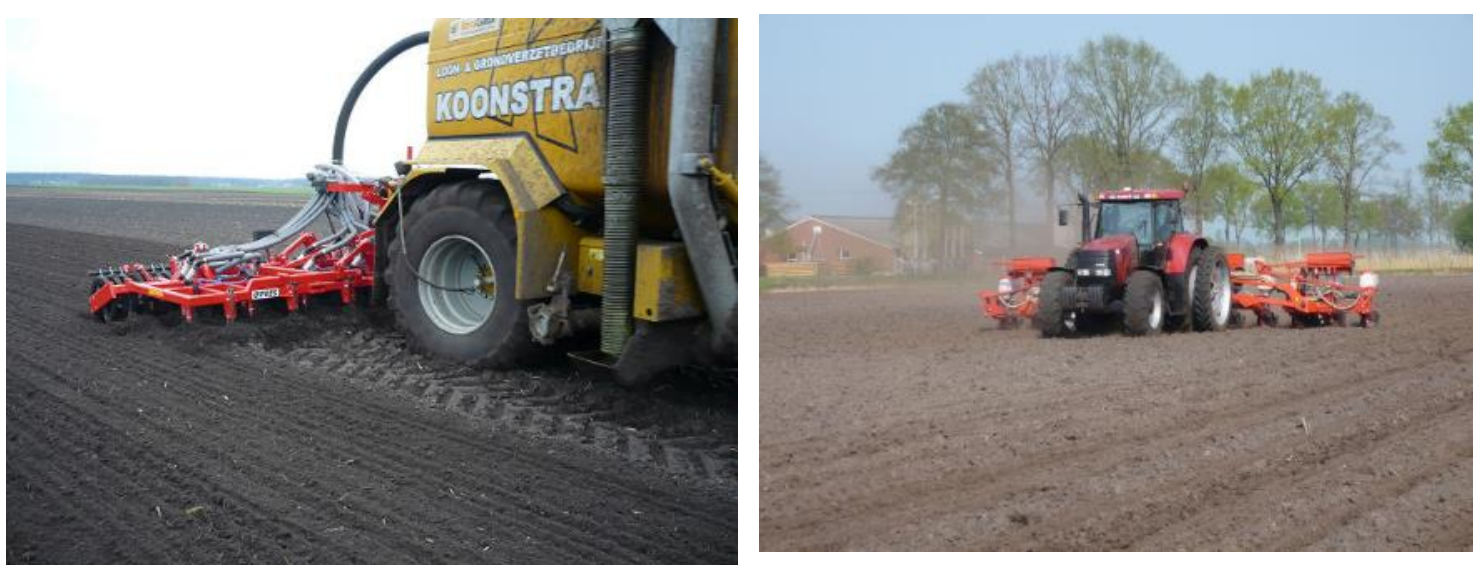
Figuur 26. Machines voor drijfmestrijenbemesting en zaaien in aparte werkgang, variant 2. Met behulp van GPS wordt de mest in 2 stroken met een tussenafstand van $25 \mathrm{~cm}$ gelegd en vervolgens wordt de mais daar midden boven gezaaid.

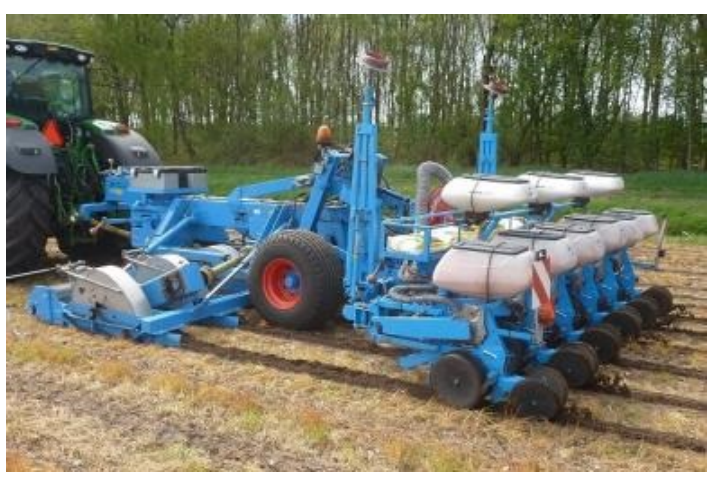

Figuur 27. Machine voor strokenfrezen en zaaien in één werkgang, variant 3

\subsubsection{Demoperceel}

De verschillende varianten zijn aangelegd op een maïsperceel waarvan de bodem wordt getypeerd als veldpodzol, bestaande uit leemarm zand met een humushoudende bovengrond van ca. $30 \mathrm{~cm}$. De grondwatertrap van het perceel varieert van Gt-III tot Gt-V. De waarnemingen aan de maïs van de verschillende varianten zijn steeds uitgevoerd op het perceelsdeel met Gt-V. In onderstaande tabel staan enkele analyseresultaten van grondmonsters van de laag 0-25 cm, genomen in maart 2015 .

Grondanalyse

\begin{tabular}{cccccc}
$\begin{array}{c}\text { Org.stof } \\
(\%)\end{array}$ & $\mathrm{pH}$ & $\begin{array}{c}\mathrm{PAl} \\
\left(\mathrm{mg} \mathrm{P} \mathrm{O}_{5} / 100 \mathrm{~g}\right.\end{array}$ & $\begin{array}{c}\mathrm{P}-\mathrm{PAE} \\
(\mathrm{mg} \mathrm{P} / \mathrm{kg})\end{array}$ & $\begin{array}{c}\mathrm{NLV} \\
(\mathrm{kg} \mathrm{N} / \mathrm{ha})\end{array}$ & $\mathrm{C} / \mathrm{N}$ ratio \\
\hline 4,4 & 4,5 & 43 & 2,9 & 23 & 22 \\
\hline
\end{tabular}

\subsubsection{Teeltactiviteiten}

Hieronder zijn de verschillende teeltactiviteiten samengevat.

9 april : Groenbemester doodspuiten met 2,5 I/ha Roundup Ultimate

19 april : Bewerking met messeneg

20 april : Veld Traditioneel bouwlandinjectie $45 \mathrm{~m}^{3} / \mathrm{ha}$

20 april : Velden Strokenteelt bemest met zodenbemester $45 \mathrm{~m}^{3} / \mathrm{ha}$

21 april : Velden Traditioneel en Drijfmestrijenbemesting ploegen+vorenpakker

23 april : Velden drijfmestrijenbemesting bemest met GPS

24 april : Veld Traditioneel zaaien plus $160 \mathrm{~kg} 25-0$ in de rij

26 april : Veld Drijfmestrijenbemesting zaaien plus $160 \mathrm{~kg} \mathrm{25-0}$ in de rij

26 april : : Alle velden $125 \mathrm{~kg} / \mathrm{ha}$ Kali60

3 mei $\quad:$ Veld Strokenteelt strokenfrezen plus zaaien in één werkgang

4 mei : Veld Strokenteelt deel vollevelds strooien $200 \mathrm{~kg} / \mathrm{ha}$ Maismap en deel $200 \mathrm{~kg} / \mathrm{ha} \mathrm{KAS}$

1 juni : Chemische onkruidbestrijding: met 1,25 L Laudis, 1,25 L Akris, 0,5 L Kart en 0,3 L

Samson per ha

7 juni : Onderzaai Italiaans raaigras met schoffel 
15 september : Land lostrekken en inzaai $25 \mathrm{~kg} / \mathrm{ha}$ Italiaans raaigras met vleugelcultivator

Maïsras: LG 30.215 en Autens

\subsubsection{Resultaten}

\subsubsection{Effect van grondbewerking op organische stof gehalte m.b.v. Verisscan}

Op het demoperceel is 4 jaar achter elkaar een deel geploegd en een deel strokenteelt toegepast. Bij aanvang van de demo is in maart 2015 de bodem gescand met de Verisscan en na 3 jaar is in maart 2018 de bodem opnieuw gescand.

In Figuur 15 zijn de taakkaarten met resultaten van het gehalte aan organische stof van 2015 en 2018 weergegeven. In de taakkaarten is het perceelsdeel wat drie jaar geploegd is en het perceelsdeel waarop drie jaar strokenteelt is toegepast zwart omlijnd. Van zowel het gedeelte wat steeds geploegd is als het gedeelte waarop steeds strokenteelt is toegepast zijn het aantal keren dat verschillende klassen van organische stofgehalten voorkwamen in 2015 en 2018 geteld. Vervolgens is op basis van deze tellingen voor beide jaren het gewogen gemiddelde gehalte aan organische stof van de beide perceelsdelen berekend. De resultaten zijn weergegeven in Figuur 16.
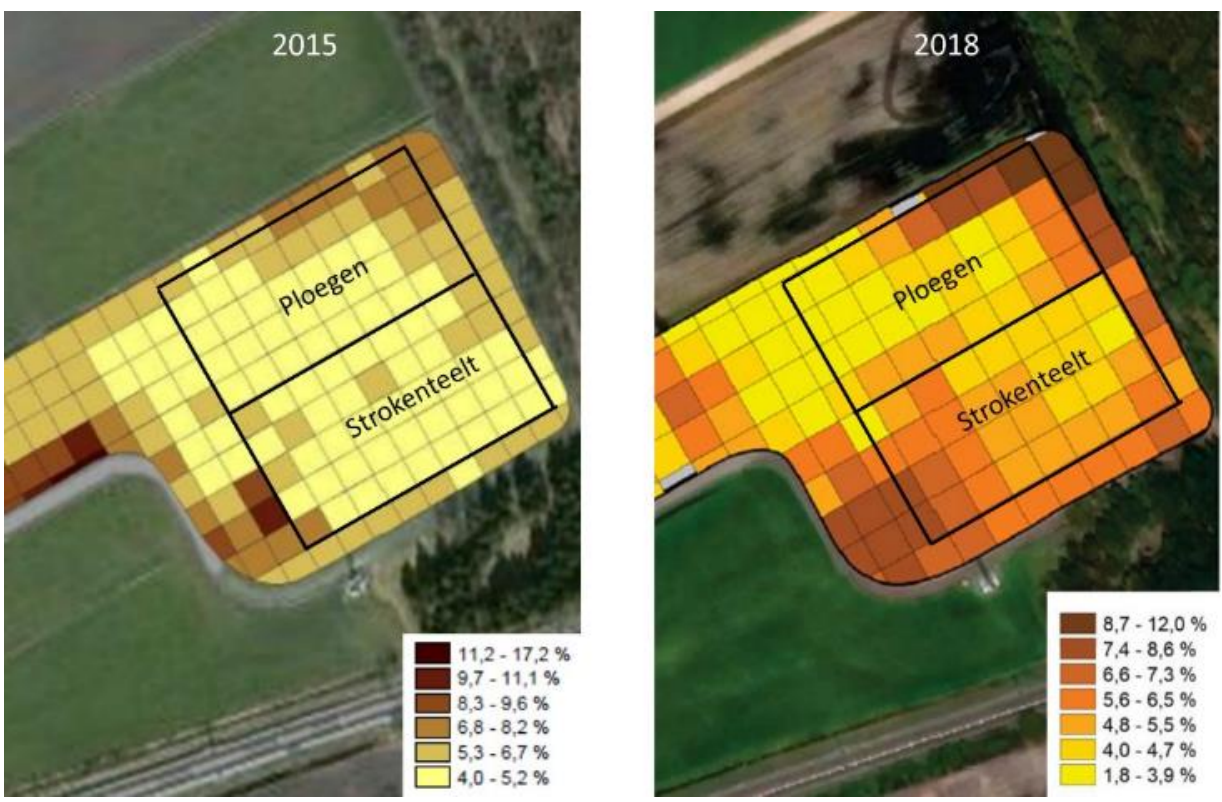

Figuur 28. Verisscan taakkaarten van het gehalte aan organische stof (laag 0-30 $\mathrm{cm}$ ) bij de uitgangssituatie in 2015 en na drie jaar ploegen of stroketeelt in 2018.

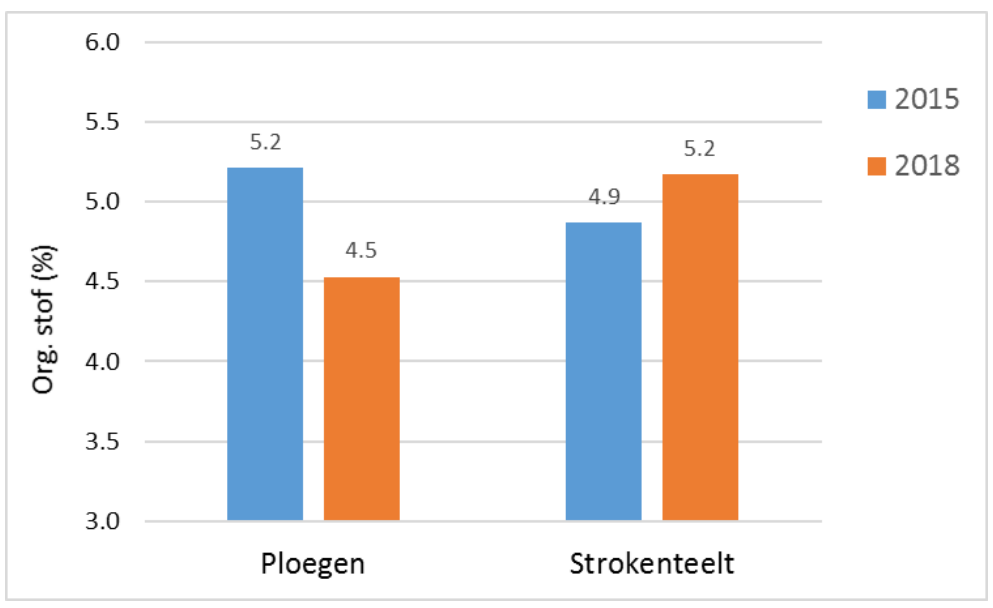


Figuur 29. Gemiddeld gehalte aan organische stof in 2015 en 2018

van de perceelsdelen die in die periode geploegd werden en die bewerkt werden met de strokenfrees.

In Figuur 29 is te zien dat bij aanvang van de demo in maart 2015 het gemiddelde organische stofgehalte van het perceelsdeel dat werd geploegd 5,2\% was en van het perceelsdeel waarop strokenteelt werd toegepast 4,9\%. Na drie jaar was het gehalte aan organische stof op het gedeelte dat jaarlijks werd geploegd gedaald tot $4,5 \%$ terwijl op het gedeelte waarop steeds strokenteelt werd toegepast het gehalte aan organische stof iets lijkt te zijn gestegen. Hoewel een daling van het organische stofgehalte van $0,7 \%$ in drie jaar op het ploeggedeelte wel erg groot is en een stijging van het gehalte aan organische stof op het strokenteeltgedeelt niet waarschijnlijk, illustreren deze resultaten toch het verschil is afbraak van organische stof tussen de intensieve methode van grondbewerken (ploegen) en beperkte grondbewerking (strokenteelt).

\subsubsection{Resultaten vanggewas 2017}

Hieronder staan enkele afbeeldingen van de stand van de vanggewassen (die in 2017 zijn gezaaid) op 14 februari en 9 april. In 2017 werd op een deel van een perceel Italiaans raaigras ondergezaaid. De ontwikkeling daarvan was wisselend. Pleksgewijs is daarom na de maisoogst alsnog Italiaans raaigras ingezaaid. Daarnaast is op een ander deel van het perceel rogge na de mais ingezaaid. Uit onderstaande afbeeldingen blijkt dat wanneer onderzaai slaagt dit leidt tot meer biomassa, vooral wortelmassa. Nazaai van rogge gaf de minste biomassa.

\section{Stand vanggewas 14 februari 2018}
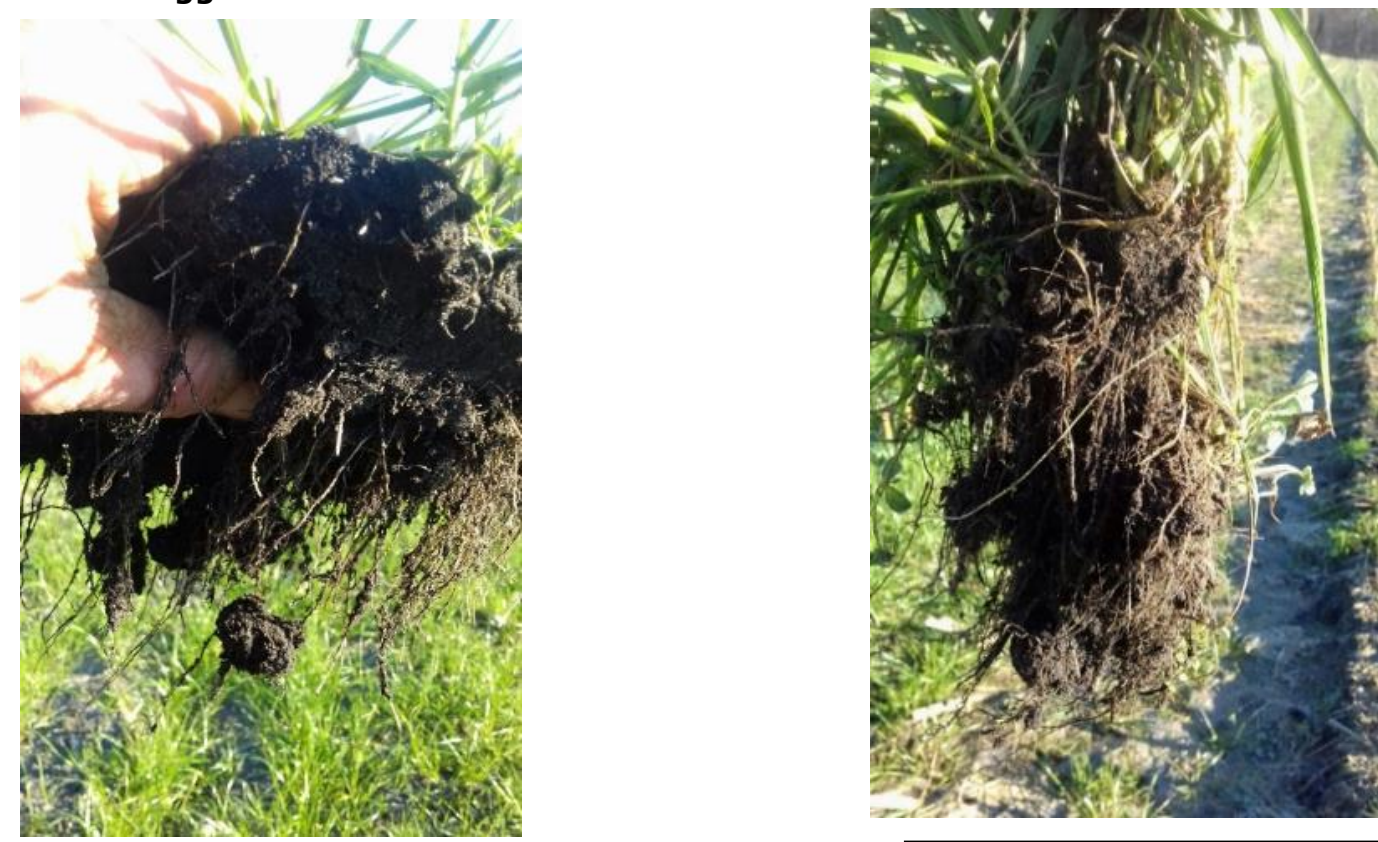

Nazaai Italiaans raaiqras

Onderzaai Italiaans raaigras 


\section{Stand vanggewas 9 april 2018}
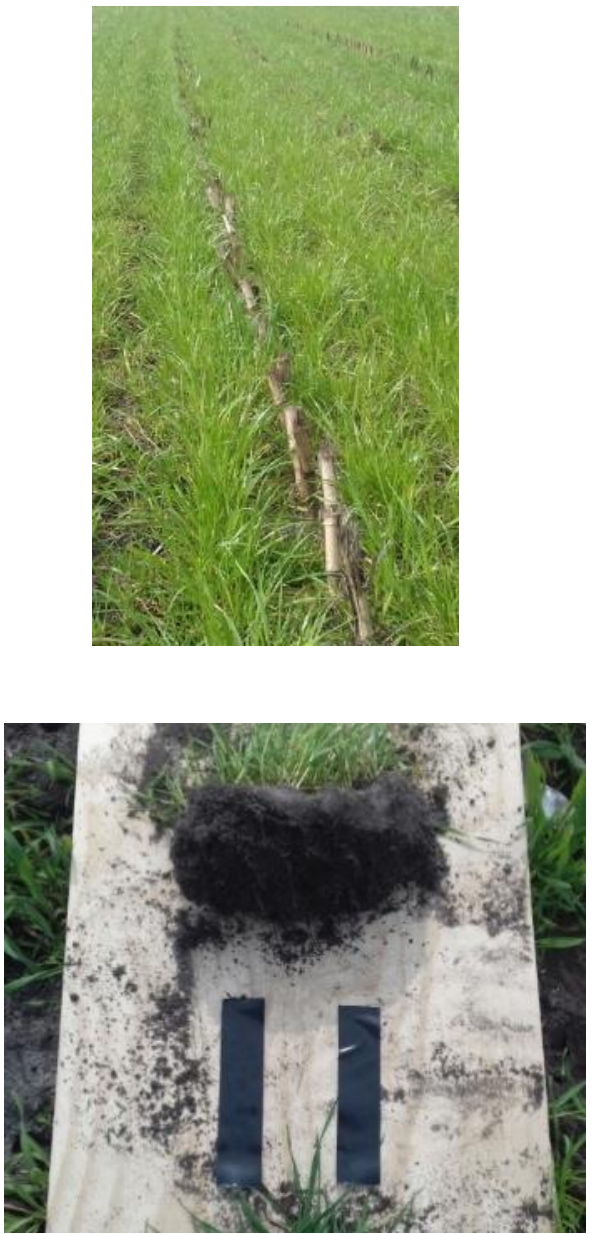

Nazaai Italiaans raaigras
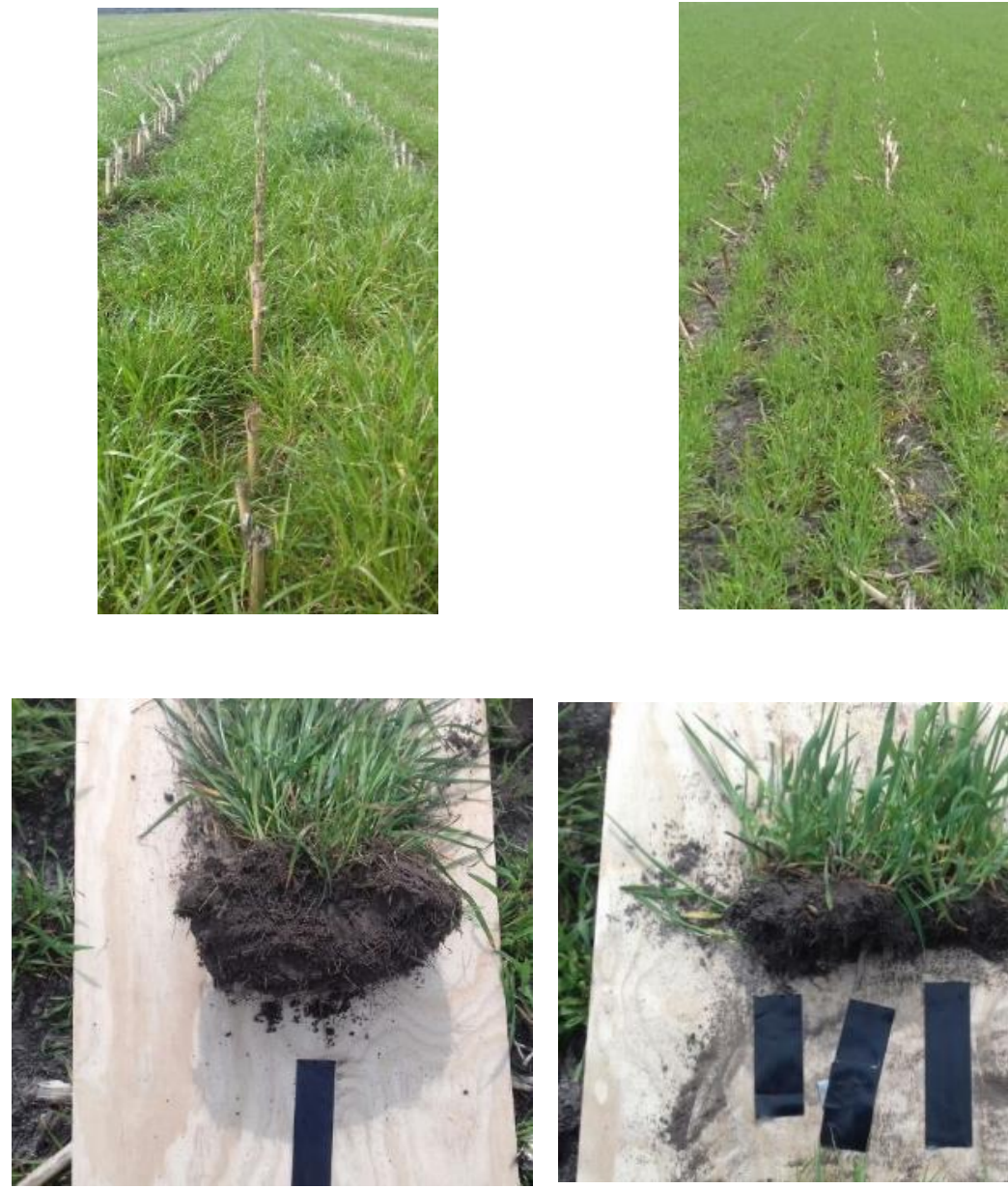

Onderzaai Italiaans raaigras

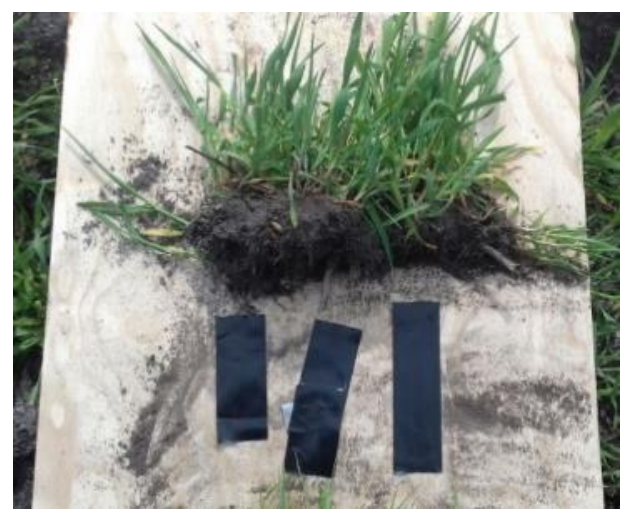

Nazaai Rogge

\subsubsection{Maisteelt 2018}

Stand mais 17 mei 2018

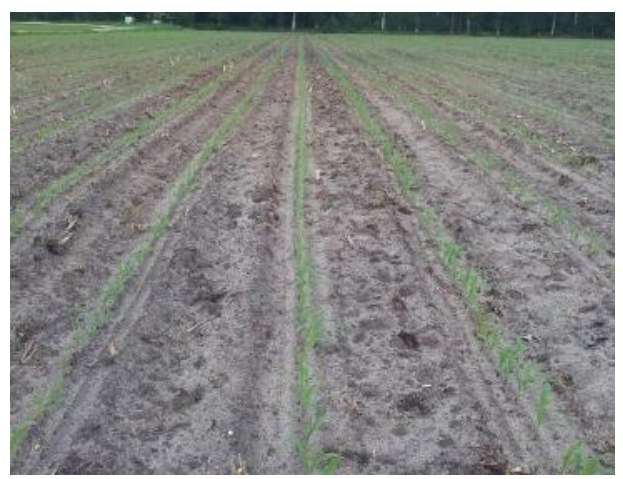

NKG

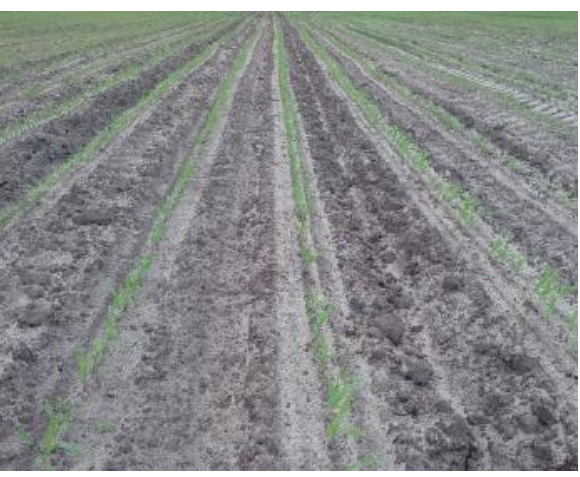

Ploegen

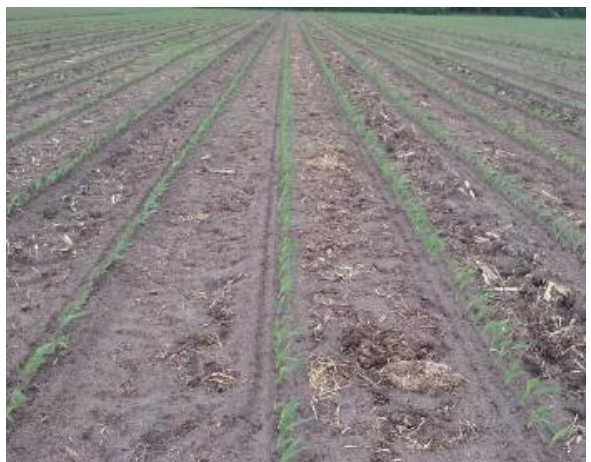

Strokenteelt 


\section{Stand mais 12 juli 2018}
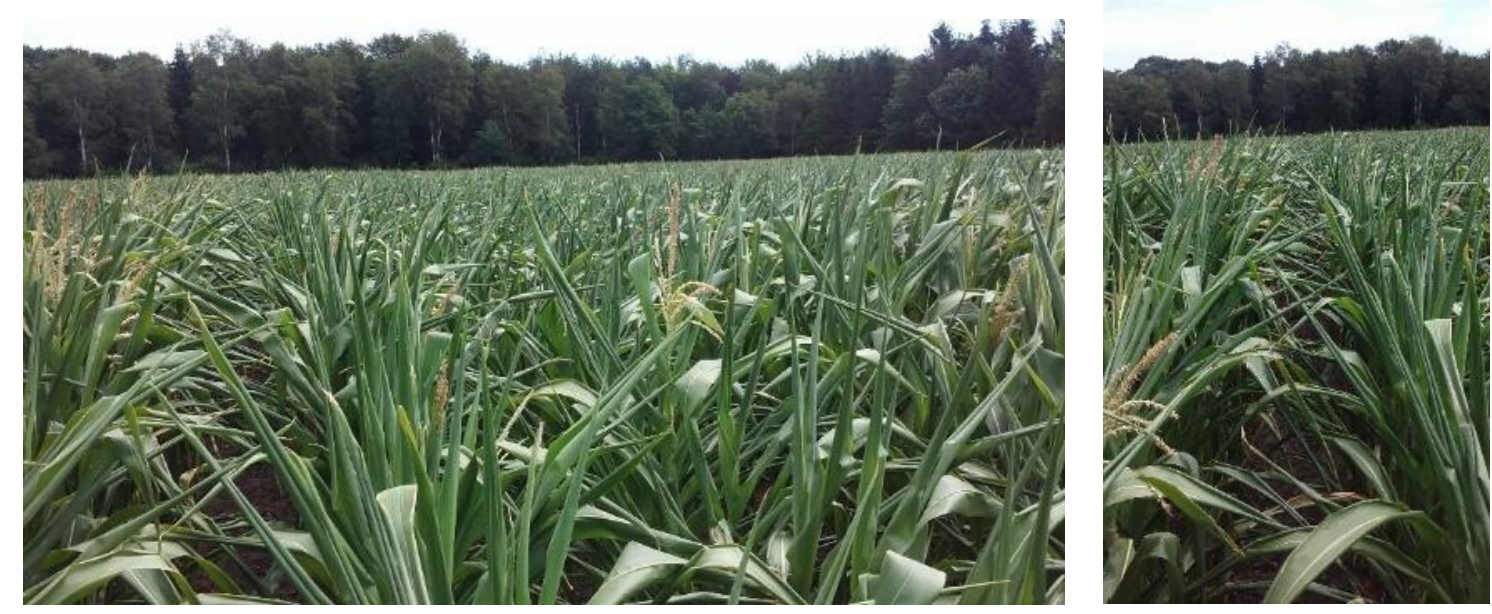

\section{Oogst 27 augustus 2018}

Het droge seizoen leidde tot een behoorlijk verdroogd maisgewas. De hoogte van de mais was gemiddeld ca. 1,5 m (zie Figuur 17). Daarom is besloten om geen opbrengsten van de verschillende zaaimethode/bemestings behandelingen te bepalen. Er zijn wel monsters genomen van een aantal behandelingen om een indruk te krijgen van de voederwaarde. De resultaten staan in Tabel 11 . Meest opvallende is dat het gehalte aan drogestof en zetmeel van de traditioneel geteelde mais hoger was dan van de mais van de overige behandelingen.

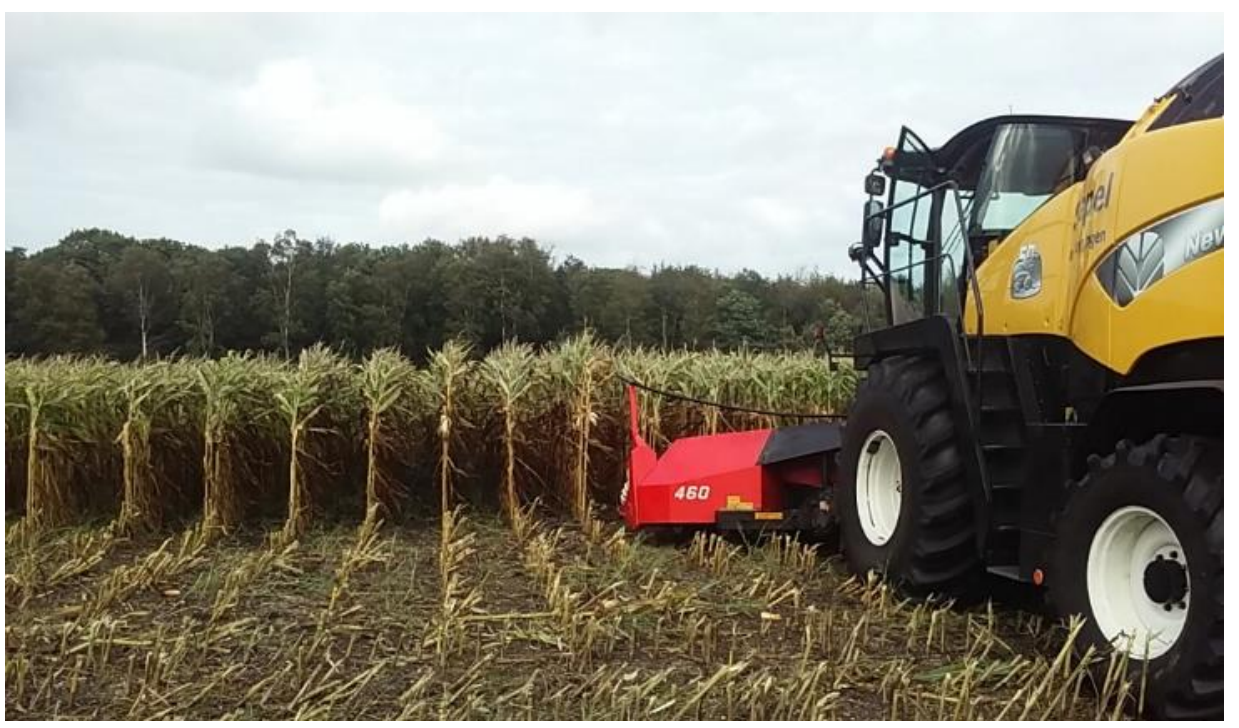

Figuur 30. Maisoogst bij Wout Graveland op 27 augustus 2018

Tabel 12. Indicatieve voerderwaardegegevens maisoogst Graveland 2018

\begin{tabular}{|c|c|c|c|}
\hline Behandeling & $\begin{array}{c}\text { Ds-gehalte } \\
(\%)\end{array}$ & $\begin{array}{c}\text { VEM } \\
\text { (/kg ds) }\end{array}$ & $\begin{array}{l}\text { Zetmeel } \\
\text { (g/kg ds) }\end{array}$ \\
\hline Traditioneel & 31,8 & 985 & 213 \\
\hline Drijfmestrijenbemesting & 28,3 & 976 & 149 \\
\hline \multicolumn{4}{|l|}{ Strokenteelt } \\
\hline Maïsmap & 28,1 & 983 & 117 \\
\hline KAS & 29,3 & 958 & 120 \\
\hline
\end{tabular}


Om een indruk te krijgen van de voederwaarde van mais wat in meer of mindere mate was verdroogd zijn monsters genomen van drie plekken waarop de mais in verschillende mate was verdroogd:

1. Licht verdroogd

2. Behoorlijk verdroogd

3. Sterk verdroogd

Onderstaand zijn afbeeldingen weergegeven van de mais met de drie gradaties van verdroging met daaronder de bijbehorende ds-gehaltes en voederwaarde. Duidelijk is te zien dat naarmate de mais meer verdroogd is, het zetmeelgehalte duidelijk lager is door slechtere kolfontwikkeling en dat daardoor het drogestofgehalte ook duidelijk lager is. Daarentegen is het suikergehalte hoger omdat er minder suikers zijn omgezet tot zetmeel. Door het hogere suikergehalte (van stengel+blad) van de verdroogde mais daalt de VEM-waarde relatief minder dan dat je op basis van het lagere zetmeelgehalte zou verwachten.
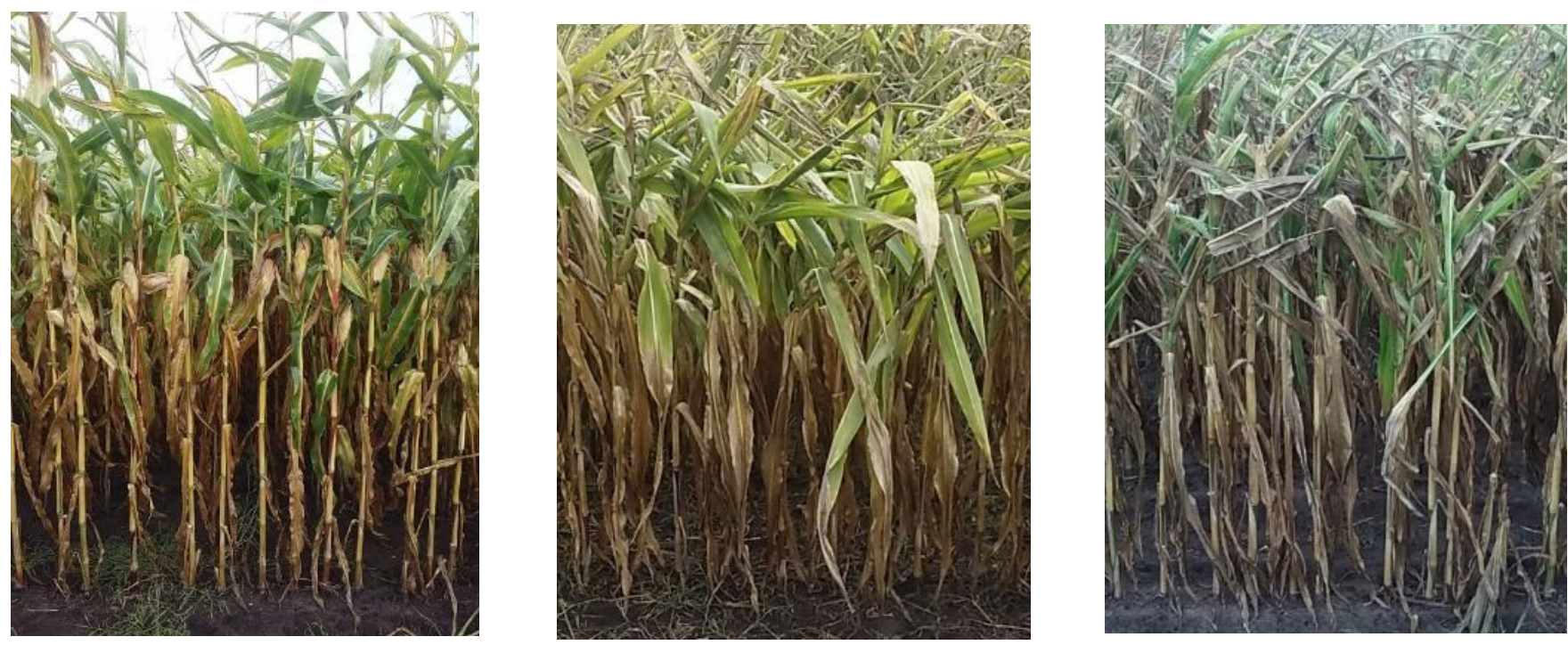

\section{Licht verdroogd}

\section{Ds\% 32,1}

VEM 1000

Zetmeel 318

Suiker 82

\section{Behoorlijk verdroogd}

\begin{tabular}{|ll|}
\hline Ds\% & 28,1 \\
VEM & 983 \\
Zetmeel & 117 \\
Suiker & 207 \\
\hline
\end{tabular}

\section{Sterk verdroogd}

\begin{tabular}{|lc|}
\hline Ds\% & 26,6 \\
VEM & 966 \\
Zetmeel & 90 \\
Suiker & 212 \\
\hline
\end{tabular}

Op 7 juni is op een perceelsdeel (zie Figuur 12) Italiaans raaigras ondergezaaid. Door de extreme droogte is de ontwikkeling hiervan echter mislukt. Op dit perceelsdeel is daarom evenalsop de andere perceelsdelen na de oogst $25 \mathrm{~kg} /$ ha Italiaans raaigras ingezaaid. 


\subsection{Scholten-Reimer}

Het bedrijf melkt ongeveer 170 koeien zonder jongvee. De 43 ha grasland en 11 ha snijmais moeten zoveel mogelijk ruwvoer produceren voor de veestapel. Alle percelen betreffen veenkoloniale dalgrond en liggen in een rotatie met een groot akkerbouwbedrijf.

\subsubsection{Huidige methode maïsteelt}

De hoofdgrondbewerking op het maisperceel bestaat uit een niet kerende grondbewerking met een vastetand-zaaibedcombinatie. Voorafgaand aan het ploegen wordt $50 \mathrm{~m}^{3} / \mathrm{ha}$ runderdrijfmest toegediend middels bouwlandinjectie. De K-bemesting wordt meestal aangevuld door 1 ton/ha Protamylasse toe te dienen voor de hoofdgrondbewerking en daarnaast $100 \mathrm{~kg} / \mathrm{ha}$ te strooien. Dit jaar is geen aanvullende K-bemesting gegeven. Bij het zaaien wordt ca. $50 \mathrm{~kg}$ stikstof in de rij gegeven.

Teamsamenstelling Gerard Scholten Reimer en Herman van Schooten (Wageningen Livestock Research)

\subsubsection{Plan van aanpak}

Het demoperceel ligt tussen Kanaal A Noordzijde (ter hoogte van nr. 11) en Eerste groenedijk Zuidzijde Dit jaar is er aandacht besteed aan onderzaai van Italiaans raaigras en Proterra, wiedeggen en de bodemverbeteraar Myrazonit.

\subsubsection{Vanggewas}

a. Gelijkzaai rietzwenkgras (Proterra)

Tussen zaaien en opkomst van de maïs werd op een strook van $20 \times 6 \mathrm{~m}^{2}$ handmatig $20 \mathrm{~kg} / \mathrm{ha}$ Proterra gezaaid en ingewerkt met het wiedeggen (zie onderstaand overzicht demoperceel).

\section{b. Onderzaai Italiaans raaigras}

Op het moment dat de maïs op kniehoogte was, werd op een deel van het perceel $25 \mathrm{~kg} / \mathrm{ha}$ Italiaans raaigras onder gezaaid met een kunstmeststrooier.

\section{c. Nazaai Italiaans raaigras}

$\mathrm{Na}$ de oogst werd op een deel van het perceel $25 \mathrm{~kg} / \mathrm{ha}$ Italiaans raaigras ingezaaid

\subsubsection{Wiedeggen}

Het perceel werd vlak voor opkomst van de maïs geegd op het moment dat het onkruid in witte draden stadium was.

\subsubsection{Myrazonit}

Op een deel van het perceel werd een demo aangelegd met de toepassing van Myrazonit. Het perceelsdeel werd opgedeel in twee subdelen waarbij op één deel Myrazonit werd toegepast en op het ander deel niet (zieFiguur 18). Zowel het subdeel met Myrazonit als het subdeel zonder werden opgedeeld in drie stroken met verschillende bemestingsniveaus:

1. $50 \mathrm{~m} 3 /$ ha runderdrijfmest bouwlandinjectie

2. $50 \mathrm{~m} 3 /$ ha runderdrijfmest bouwlandinjectie $+25 \mathrm{~kg} \mathrm{~N} /$ ha rijenbemesting bij zaaien

3. $50 \mathrm{~m} 3 /$ ha runderdrijfmest bouwlandinjectie $+50 \mathrm{~kg} \mathrm{~N} /$ ha rijenbemesting bij zaaien 


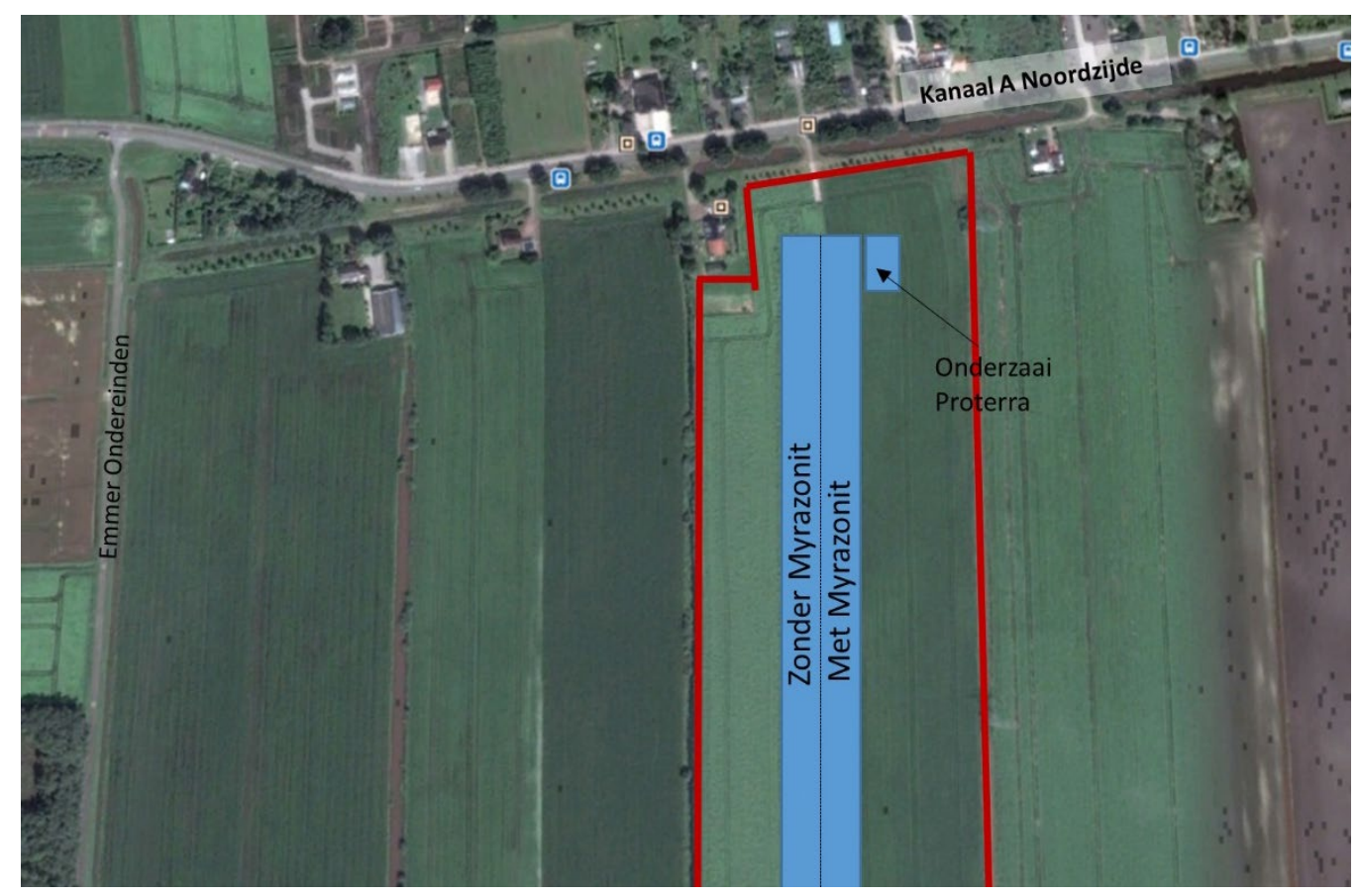

Figuur 31 Schematisch overzicht demoperceel Scholten-Reimer 2018.

\subsubsection{Demoperceel}

Het demoperceel was een perceel van de buurman waar grond mee geruild wordt. De grondsoort van het demoperceel wordt gekenmerkt als moerig zand met een organische stofgehalte van de bovengrond varierend van 8 tot 15\%. De grondwatertrappen binnen het perceel varieren van IIIb (grootste deel) tot VI (https://www.provincie.drenthe.nl/@81831/bodematlas).

Begin mei is een grondmonster genomen van de laag 0-25 cm voor bemestingsonderzoek. De resultaten staan in Tabel 12.

Tabel 13. Resultaten grondmonster voor bemestingsonderzoek van de laag $0-25 \mathrm{~cm}$ op het demoperceel van Gerard Scholten-Reimer.

\begin{tabular}{|c|c|c|}
\hline Parameters & Resultaat & Beoordeling \\
\hline Organische stof (\%) & 13,6 & \\
\hline $\mathrm{pH}$ & 4,7 & Vrij laag \\
\hline N-totaal bodemvoorraad (kg/ha) & 9370 & Vrij hoog \\
\hline $\mathrm{C} / \mathrm{N}$-ratio & 21 & Vrij hoog \\
\hline $\mathrm{N}$-leverend vermogen ( $\mathrm{Kg} \mathrm{N} / \mathrm{ha})$ & 75 & Vrij laag \\
\hline S-totaal bodemvoorraad (kg S/ha) & 1080 & Goed \\
\hline C/S-ratio & 183 & Hoog \\
\hline S-leverend vermogen (kg S/ha) & 1 & Laag \\
\hline P-plantbeschikbaar (kg P/ha) & 11,8 & Hoog \\
\hline P-bodemvoorraad (kg P/ha) & 340 & Goed \\
\hline K-plantbeschikbaar (kg K/ha) & 250 & Goed \\
\hline K-bodemvoorraad (kg K/ha) & 225 & Vrij laag \\
\hline Mg-plantbeschikbaar (kg Mg/ha) & 350 & Hoog \\
\hline
\end{tabular}




\subsubsection{Teeltactiviteiten}

Hieronder zijn de verschillende teeltactiviteiten samengevat.

Voorjaar 2018: Diepspitten voor grondverbetering

7 mei : $50 \mathrm{~m}^{3} /$ ha bouwlandinjectie runderdrijfmest $\left(3,2 \mathrm{~kg} \mathrm{~N} \mathrm{1,3} \mathrm{kg} \mathrm{P}_{2} \mathrm{O}_{5}\right.$ en $\mathrm{kg} \mathrm{4,8} \mathrm{K}_{2} \mathrm{O}$ per

$8 \mathrm{mei}:$ Myrazonit $20 \mathrm{l} / \mathrm{ha}$ toegediend met veldspuit

8 mei : Grondbewerking met vaste tand cultivator + vorenpakker

9 mei : Zaaien + N-rijenbemesting volgens plan

14 mei : Strookje handmatig onderzaai Rietzwenkgras (Proterra, 20 kg/ha)

15 mei : Wiedeggen

1 juni : Onkruidbestrijding (1,25 I Laudis, 0,3 I Samson en 0,6 I Kart per ha)

9 juni : Hele perceel onderzaaien met Italiaans raaigras met kunstmeststrooier

29 sept : Oogst

10 okt : Nazaai Italiaansraaigras met Lemken Smaragd met opgebouwde zaaimachine

Maïsras: Dairymaïs vroeg

\subsubsection{Resultaten}

\subsubsection{Milieubelastingspunten (MBP) onkruidbestrijding}

Met de milieumeetlat open teelten (www.mileumeetlat.nl) zijn de milieubelastingspunten van de toegepaste gewasbeschermingsmiddelen berekend. Onderstaand is het resultaat weergegeven.

De totale hoeveelheid werkzame stof van de toegepaste mix is met 0,16 kg per ha laag. De mbp van alle toegepaste middelen blijven voor alle drie criteria (waterleven, bodemleven en grondwater) duidelijk onder de risicogrens van 100 punten. Ook opgeteld blijft de mix voor alle drie criteria onder de 100 punten.

\begin{tabular}{|c|c|c|c|c|c|c|c|}
\hline \multirow[b]{2}{*}{ Middel } & \multirow[b]{2}{*}{$\begin{array}{l}\text { Werkz. stof } \\
\text { (kg/ha) }\end{array}$} & \multicolumn{3}{|c|}{ Milieubelastingpunten } & \multicolumn{3}{|c|}{ Risico } \\
\hline & & Waterleven & Bodemleven & Grondwater & Bestuivers & Bestrijders & Toepasser \\
\hline LAUDIS & 0.055 & 36 & 23 & 0 & A & $?$ & I \\
\hline $\begin{array}{l}\text { SAMSON EXTRA } 6 \% \\
\text { OD }\end{array}$ & 0.018 & 42 & 3 & 2 & B & $?$ & I \\
\hline KART & 0.087 & 21 & 66 & 7 & A & $?$ & । \\
\hline
\end{tabular}

\begin{tabular}{|lllll}
\hline Waterleven, bodemleven en grondwater & Nuttige organismen & \multicolumn{2}{c}{ Risico toepasser } \\
$0-100 \mathrm{MBP}$ & A Bruikbaar in geintergr. teelt & I & Irriterend \\
$100-1000 \mathrm{MBP}$ & B Beperkt bruikbaar & S & Schadelijk \\
$>1000 \mathrm{MBP}$ & C Niet bruikbaar & G & Giftig \\
& ? Onbekend & ZG Zeer giftig \\
\hline & & B Bijtend
\end{tabular}

\subsubsection{Vanggewas}

Vijf dagen nadat de mais gezaaid was is op een kleine oppervlakte (ca $10 \times 4 \mathrm{~m}^{2}$ ) handmatig $20 \mathrm{~kg} / \mathrm{ha}$ rietzwenkgras (Proterra) gezaaid. Op 9 juni (een maand na mais zaaien) is op de helft van het perceel $25 \mathrm{~kg} / \mathrm{ha}$ Italiaans raaigras ondergezaaid met de kunstmeststrooier. Aangezien er een lange droge periode volgde is het meeste zaad pas gekiemd na de droge periode in augustus. Op onderstaande foto's is de stand weergegeven op 5 oktober, een week na de maisoogst. Hierop is te zien dat naast het 
rietzenkgras ook het Italiaans raaigras relatief goed ontwikkeld was ondansk dat het met de kunstmeststrooier gestrooid was zonder inwerken.

\section{Stand onderzaai op 5 oktober (1 week na oogst)}

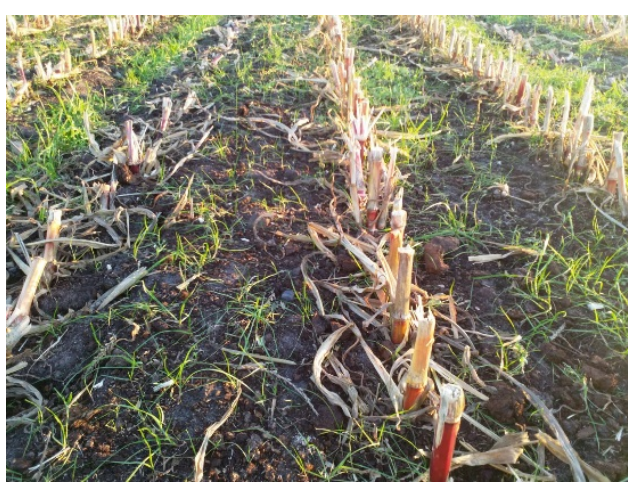

Italiaans raaigras

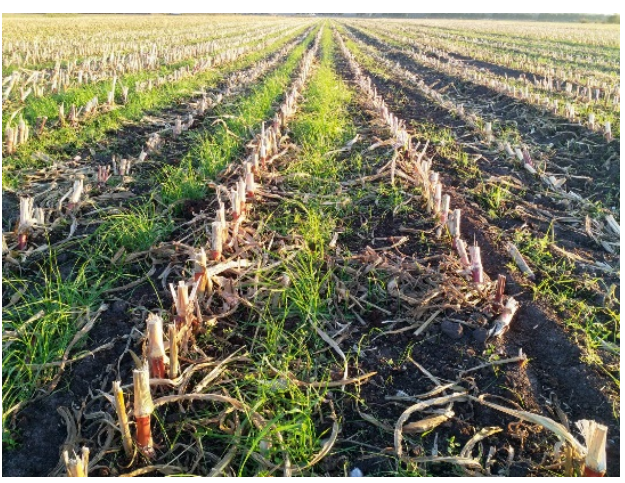

Italiaans raaigras

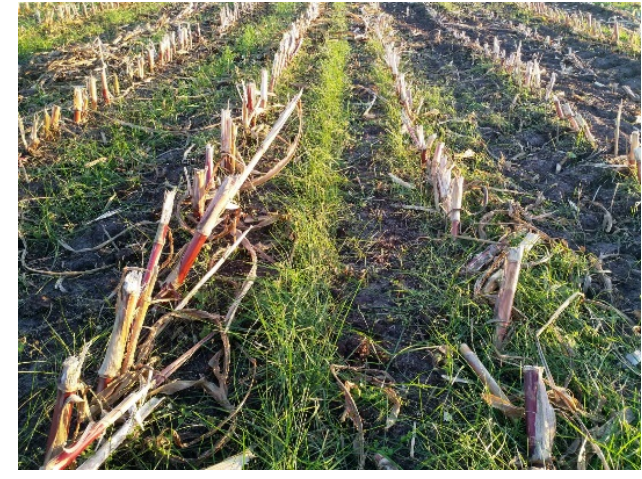

Rietzwenkgras

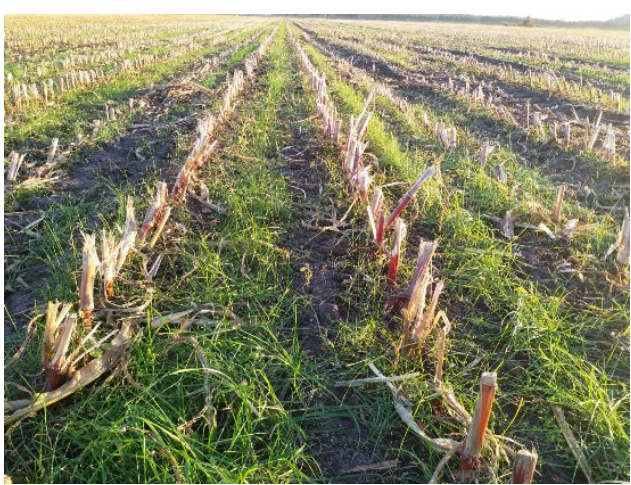

Rietzwenkgras 


\section{Stand onderzaai en nazaai op 15 december}

$\mathrm{Na}$ de maisoogst is op 10 oktober op de helft van het perceel $25 \mathrm{~kg} / \mathrm{ha}$ Italiaans raaigras gezaaid. Op onderstaande foto's is de stand van de ondergezaaide rietzwenkgras en Iltaliaans raaigras en de nagezaaide Italiaans raaigras te zien op 15 december. Duidelijk is te zien dat de onderzaai beter ontwikkeld is dan de nazaai.
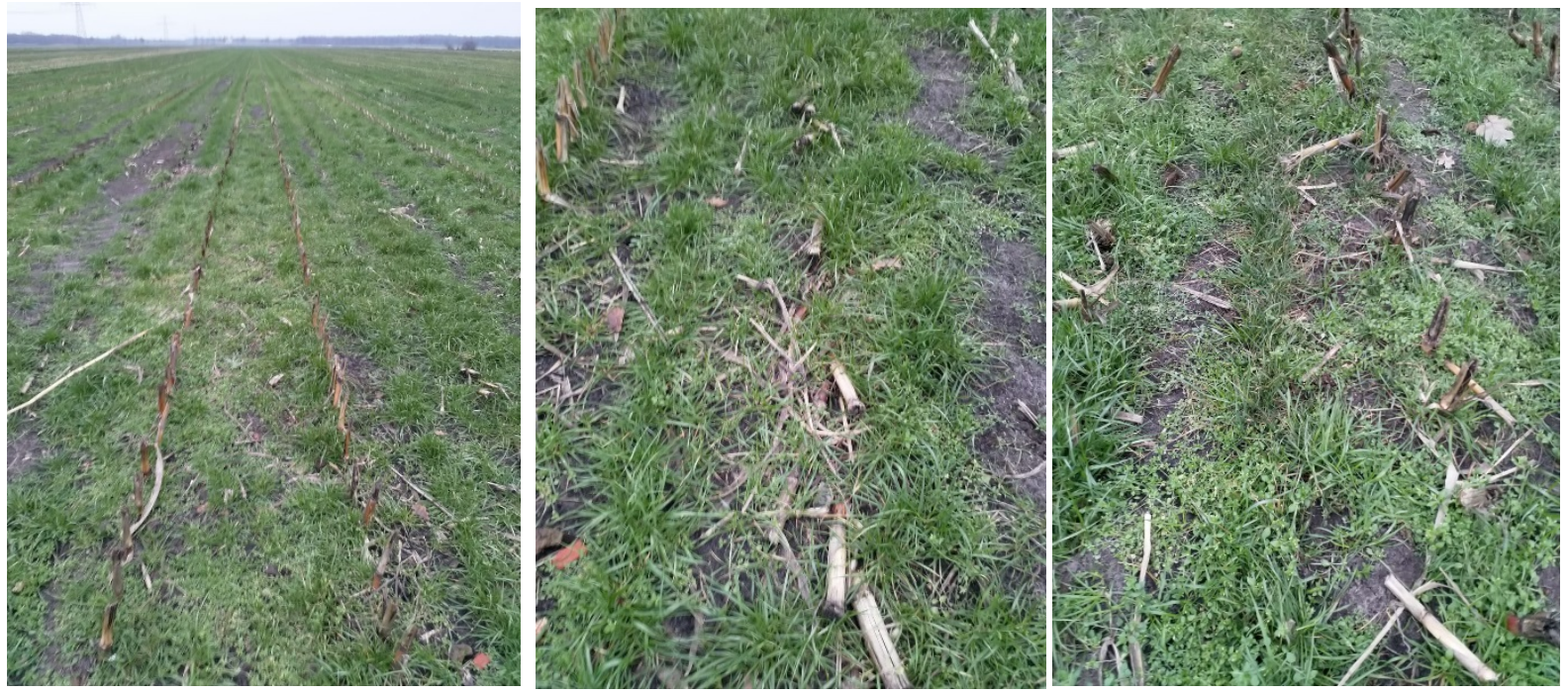

Onderzaai overzicht

Onderzaai Italiaans raaigras

Onderzaai Rietzenkgras
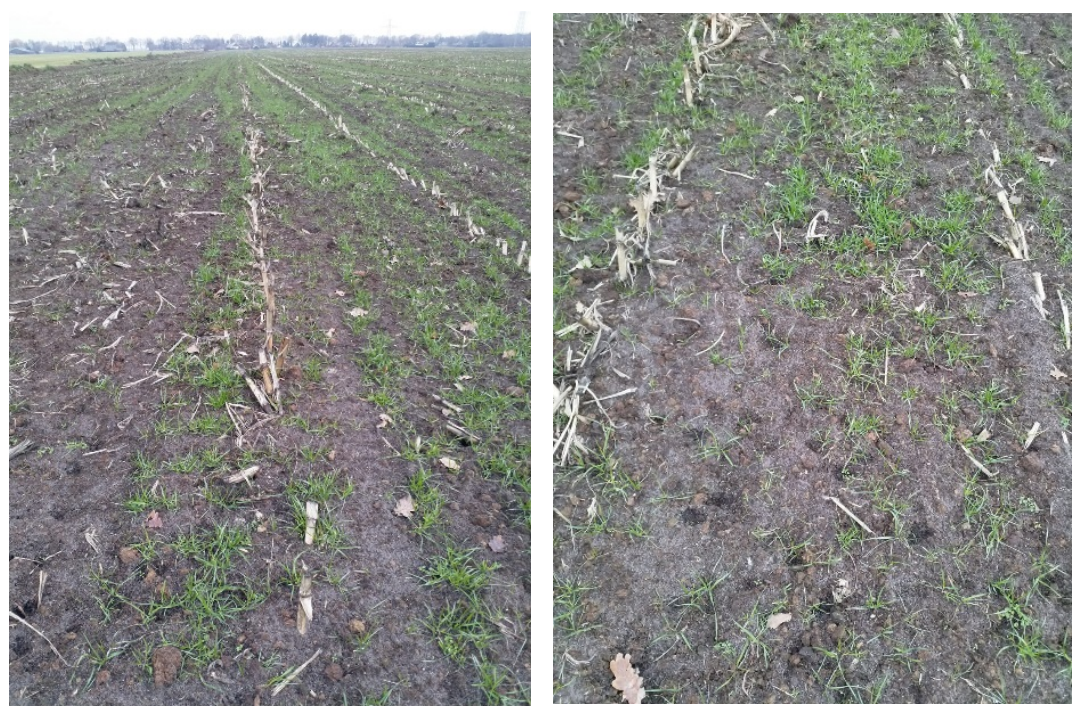

Nazaai Italiaans raaigras

\subsubsection{Opbrengstresultaten Myrazonit demo}

Op 29 september werd de mais geoogst. Tijdens de oogst werd de opbrengst per behandeling afzonderlijk bepaald. Daartoe werd de maïs per werkgang over een lengte van $250 \mathrm{~m}$ in een silagewagen gehakselde en vervolgens gewogen met een weegbrug. Tijdens het lossen op de kuil werd per werkgang een monsters genomen voor analyse op voederwaarde door Eurofins-Agro. De resultaten zijn weergeven in Tabel 13. De gemiddelde drogestofopbrengst van de stroken met Myrazonit was hoger dan die van de stroken zonder Myrazonit. De stroken met en zonder Myrazonit waren echter om praktische redenen niet afwisselend aangelegd, maar lagen tegen elkaar aan op één perceelsdeel. 
Hierdoor kan niet beoordeeld worden in hoeverre het verschil werd veroorzaakt door de behandeling met Myrazonit en/of door verschil in (bodem)omstandigheden tussen de beide perceelsdelen.

Tabel 14. Indicatieve opbrengst en voederwaardegegevens maisopbrengst Scholten-Reimer

\begin{tabular}{|c|c|c|c|c|c|}
\hline \multirow[t]{2}{*}{ Behandelingen } & \multicolumn{3}{|c|}{ Opbrengst } & \multicolumn{2}{|c|}{ Voederwaarde } \\
\hline & $\begin{array}{c}\text { Verse } \\
\text { (ton/ha) }\end{array}$ & $\begin{array}{c}\text { Ds-gehalte } \\
(\%)\end{array}$ & $\begin{array}{c}\text { Drogestof } \\
\text { (ton/ha) }\end{array}$ & $\begin{array}{c}\text { VEM } \\
\text { (/kg ds) }\end{array}$ & $\begin{array}{c}\text { Zetmeel } \\
\text { (g/kg ds) }\end{array}$ \\
\hline Met Myrazonit $+0 \mathrm{~N}$ & 45,3 & 43,0 & 19,5 & 1021 & 446 \\
\hline Met Myrazonit $+25 \mathrm{~N}$ & 47,3 & 43,8 & 20,7 & 1031 & 447 \\
\hline Met Myrazonit $+50 \mathrm{~N}$ & 49,3 & 44,7 & 22,1 & 1034 & 455 \\
\hline Zonder Myrazonit + $0 \mathrm{~N}$ & 41,1 & 43,2 & 17,7 & 1006 & 450 \\
\hline Zonder Myrazonit + $25 \mathrm{~N}$ & 42,3 & 44,0 & 18,7 & 1018 & 435 \\
\hline Zonder Myrazonit + $50 \mathrm{~N}$ & 41,5 & 43,3 & 17,9 & 1034 & 443 \\
\hline
\end{tabular}




\subsection{Kievit}

Bedrijf: Mts Kievit.

Mts Kievit heeft diverse onderzaaisels getoetst i.s.m. Menno Jansen (loonwerk).

Mts Kievit is in de afgelopen jaren actief geweest met verschillende soorten onderzaai en is daarmee in 2018 doorgegaan. Uit de voorgaande jaren bleek dat vooral rode klavers zich goed ontwikkelden. Wikke en witte klaver presteerden minder goed. Daarnaast heeft Mts Kievit geëxperimenteerd met andere grassoorten. Een veelbelovende, niet winterhard gras bleek Kropaar. Hierdoor kon het relatief gemakkelijk worden ondergewerkt. Het zaaizaad van de niet winterharde kropaar blijkt in vergelijking met Italiaans Raaigras vrij kostbaar en omdat ook de productie van organische stof lager lag, is Mts Kievit hiermee gestopt. Als alternatief is in 2018 geëxperimenteerd met een hogere zaaizaadhoeveelheid aan Italiaans Raaigras. Dit had als doel om een dichtere graszode te creëren rond de maisoogst met uiteindelijk meer biomassa productie als doel. Ook is er in 2018 is er geëxperimenteerd met boekweit als onderzaai. De boekweit leek als onderzaaigewas niet geschikt te zijn omdat het afrijpt en daarna geen nutrienten meer opneemt.

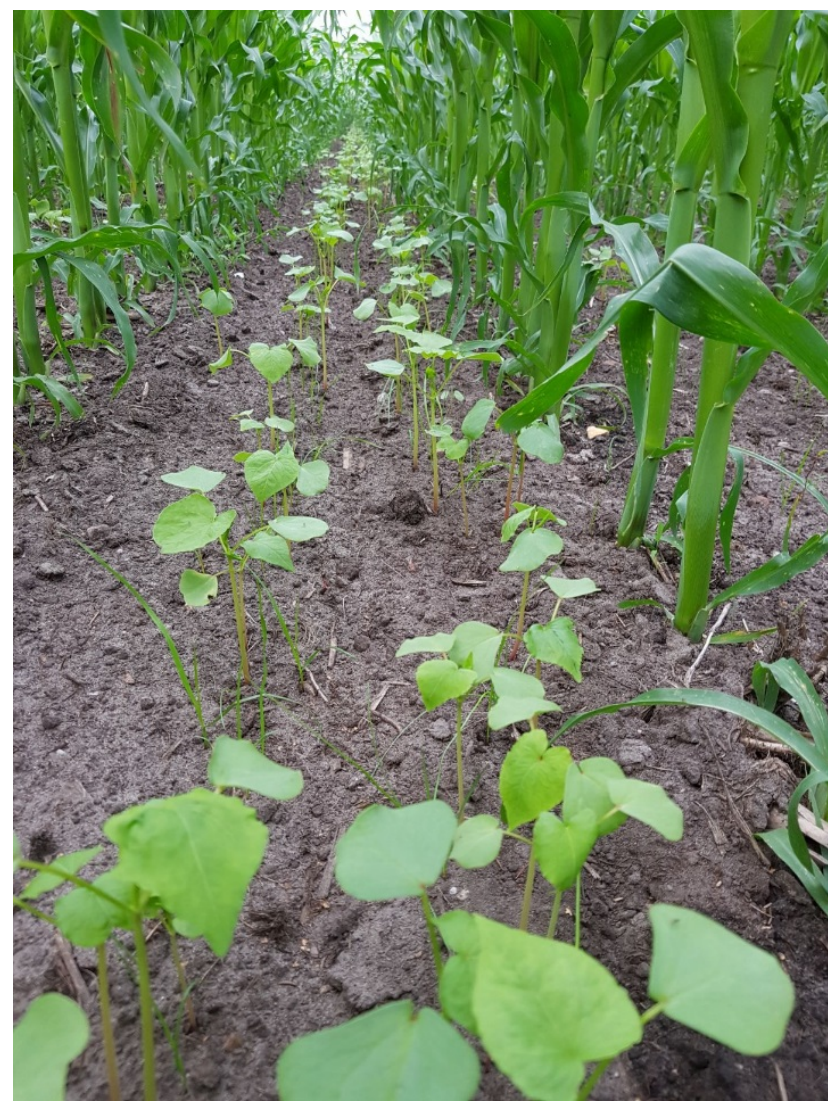

Figuur 32. De ondergezaaide boekweit ontwikkelde zich aanzienlijk sneller dan de mais.

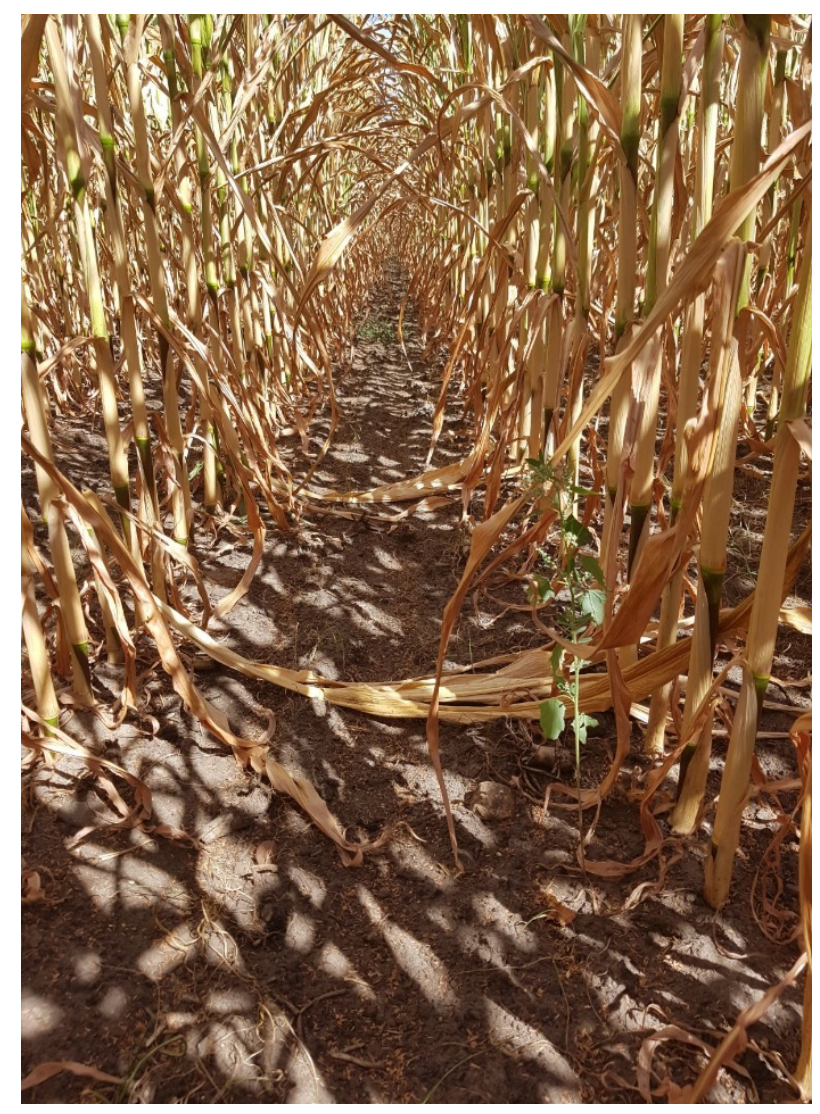

Figuur 33. Extreem verdroogde mais kort voor de oogst.

Hoewel het groeiseizoen startte met zware regenval, volgde een droge zomer. Hierdoor is de mais verdroogd (zie Figuur 20). De mais is om die reden vroeg gehakseld (15 augustus). De mais bevatte $143 \mathrm{~g} / \mathrm{kg}$ drogestof zetmeel. De onderzaai was door de droogte vrijwel volledig verloren gegaan. Hierdoor is er besloten om na de oogst opnieuw gras in te zaaien. 


\section{$4.4 \quad$ Meijer}

In 2018 heeft bij het satellietbedrijf van Grondig Boeren Met Mais (GBMM) een demo gelegen met de volgende thema's. De demo is aangelegd door Familie Meijer met samenwerking van WPA (F Weites), Visscher Holland (H. Kelderhuis), KWS (A. Lassche), WUR openteelten M. Wesselink/ J. Specken.

Thema's 2018

- $\quad$ Rasvergelijk (Megusto (KWS), LG 31-205, Autens en Benedicto (KWS))

- $\quad$ Effect ras (bladstand, forsheid gewas etc) i.r.t. de onderzaai

- Vergelijking onderzaai (italiaans raaigras, Italiaans Raaigras + rode klaver, Japanse Haver, Maisgras en Landsberger Gemenge) met nazaai van japanse haver, italiaans Raaigras en maisgras.

- Vergelijking onderzaai in het 6-bladstadium versus onderzaai met Rietzwenkgras

- Vergelijk $40 \mathrm{~kg} \mathrm{~N} / \mathrm{ha}$ in de rij versus mycorrhiza ipv minerale stikstof

De onkruidbeheersing op het perceel is uitgevoerd volgens het LDS-systeem waarbij twee bespuitingen zijn uitgevoerd. Het doel hierbij is om in een vroeg stadium met een lagere dosering te spuiten omdat de onkruiden kleiner en gemakkelijker te bestrijden zijn. Hierbij is in het 1-2 bladstadium $1 \mathrm{l} /$ ha Laudis gespoten en 31 mei 1 liter Laudis + 0,25 I/ha Milagro en 0,5 I/ha Kart. Vanwege de onderzaai is geen gebruik gemaakt van een bodemherbicide.

In het seizoen is een veldbijeenkomst georganiseerd om de resultaten te tonen aan geïnteresseerden. Deze bijeenkomst werd 5 september gehouden.

De mais is 13 september geoogst en zijn er voederwaarde monsters genomen. Bij afloop is de $\mathrm{N}$ mineraal in de bodem vastgesteld.

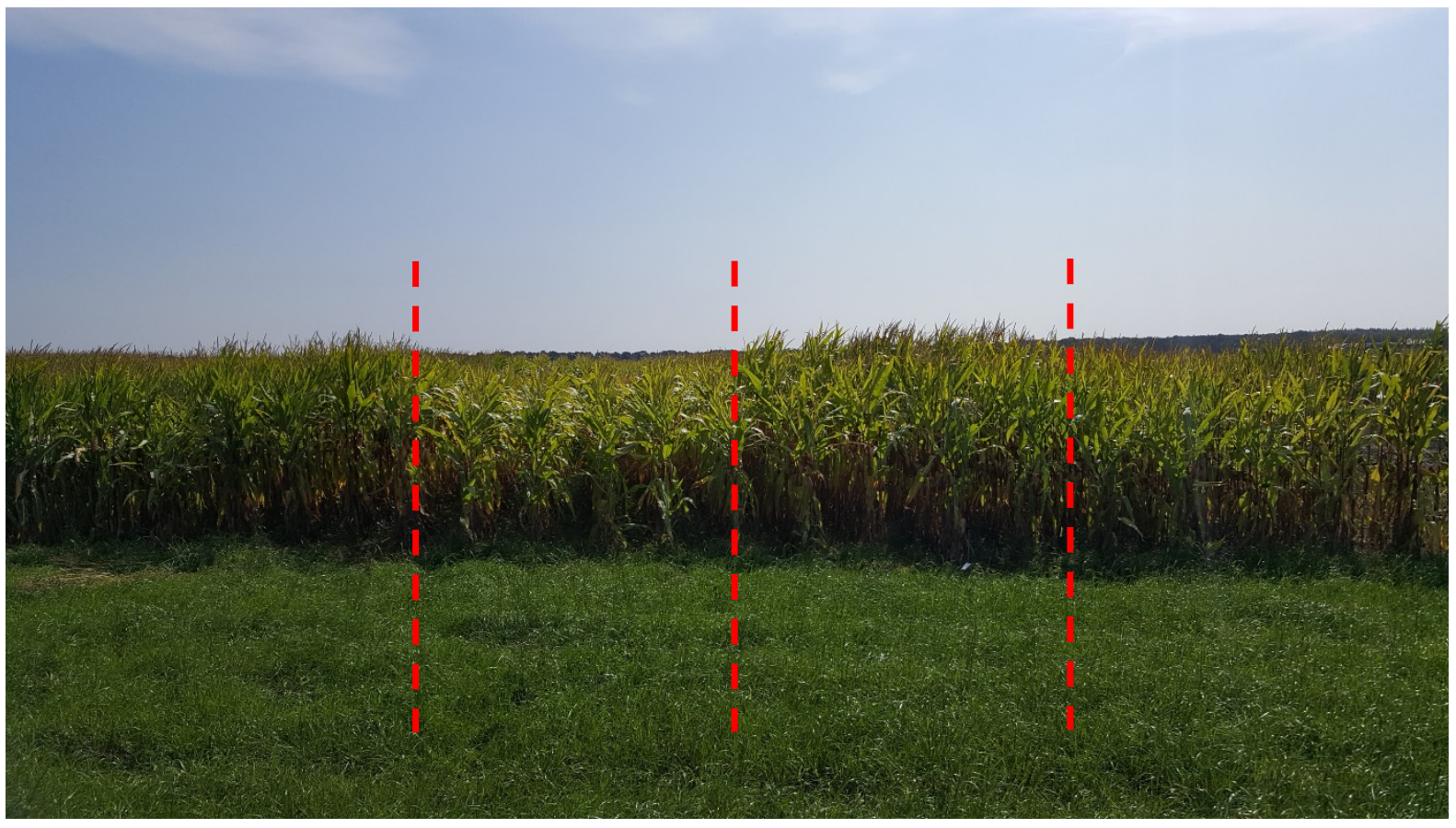

Figuur 35. Maisstand 5 september. Van links naar rechts: Benedicto, LG31.205, Benedicto en Megusto.

Uit Figuur 35 blijken duidelijk rasverschillen in de mais. Het ras Benedicto staat het meest massaal. Dit werd ook gemeten in de versopbrengst (Tabel 16), hier had Benedicto het hoogste resultaat. In het veld waren er ook duidelijk verschillen in bladstand en daarmee lichtinval zichtbaar. 
Tabel 15. Opzet demo satellietbedrijf Meijer 2018

\begin{tabular}{|c|c|c|c|c|c|c|c|c|c|c|c|c|c|c|c|c|c|c|c|c|c|}
\hline \multicolumn{4}{|c|}{ Object 1 effect mycorrhiza vs minerale $\mathrm{N}$ in de rij } & \multicolumn{15}{|c|}{ Object 2 rassen en onderzaai demo } & \multicolumn{3}{|c|}{ Object 3 onderzaai Proterra } \\
\hline 16 rij Autens & \multicolumn{3}{|c|}{16 Autens + mycorrhiza } & \multicolumn{5}{|c|}{ Megusto } & \multicolumn{5}{|c|}{ Benedicto } & \multicolumn{5}{|c|}{ LG31205 } & LG31205 & Benedicto & Megusto \\
\hline \multicolumn{4}{|l|}{ nazaai } & \multicolumn{5}{|c|}{ onderzaai } & \multicolumn{5}{|c|}{ onderzaai } & \multicolumn{5}{|c|}{ onderzaai } & bij zaai & & \\
\hline \multicolumn{4}{|l|}{ cocktail 1} & \multicolumn{5}{|c|}{ cocktail 2} & \multicolumn{5}{|c|}{ cocktail 2} & \multicolumn{5}{|c|}{ cocktail 2} & \multicolumn{3}{|l|}{ cocktail 3} \\
\hline \multicolumn{4}{|c|}{40 m3 RDM volvelds } & \multicolumn{18}{|c|}{$40 \mathrm{~m} 3 / \mathrm{ha}$ volvelds } \\
\hline \multicolumn{4}{|c|}{ geen kunstmest $\mathrm{N}$} & \multicolumn{18}{|c|}{150 MM 25-0 } \\
\hline \multicolumn{4}{|l|}{ geen extra $\mathrm{K} 2 \mathrm{O}$} & \multicolumn{18}{|c|}{100 kg K60 na zaai } \\
\hline 16 rijen Autens & \multicolumn{3}{|c|}{$\begin{array}{l}16 \text { rijen Autens + } \\
\text { Mycorrhiza }\end{array}$} & \multicolumn{5}{|c|}{40 rijen Megusto } & \multicolumn{5}{|c|}{40 rijen Benedicto } & \multicolumn{5}{|c|}{40 rijen LG 31205} & 1 baan & 1 baan & 1 baan \\
\hline
\end{tabular}

De proef is 7 mei gezaaid en dag later is de Proterra ondergezaaid. De onderzaai in het 6-bladstadium is 14 juni uitgevoerd. 


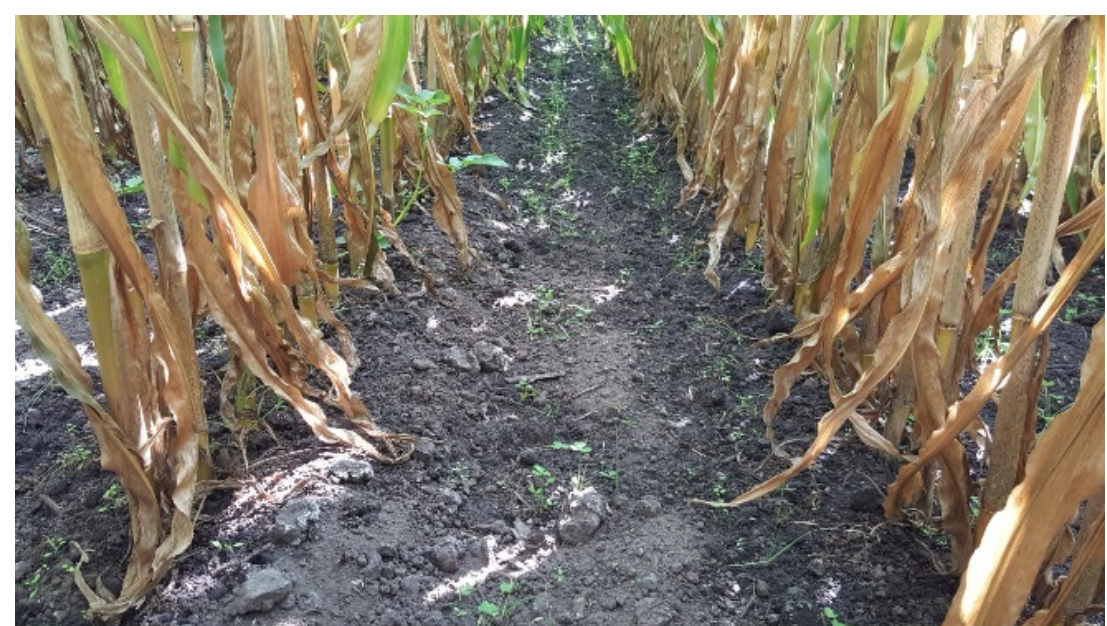

Onderzaai met Italiaans Raaigras

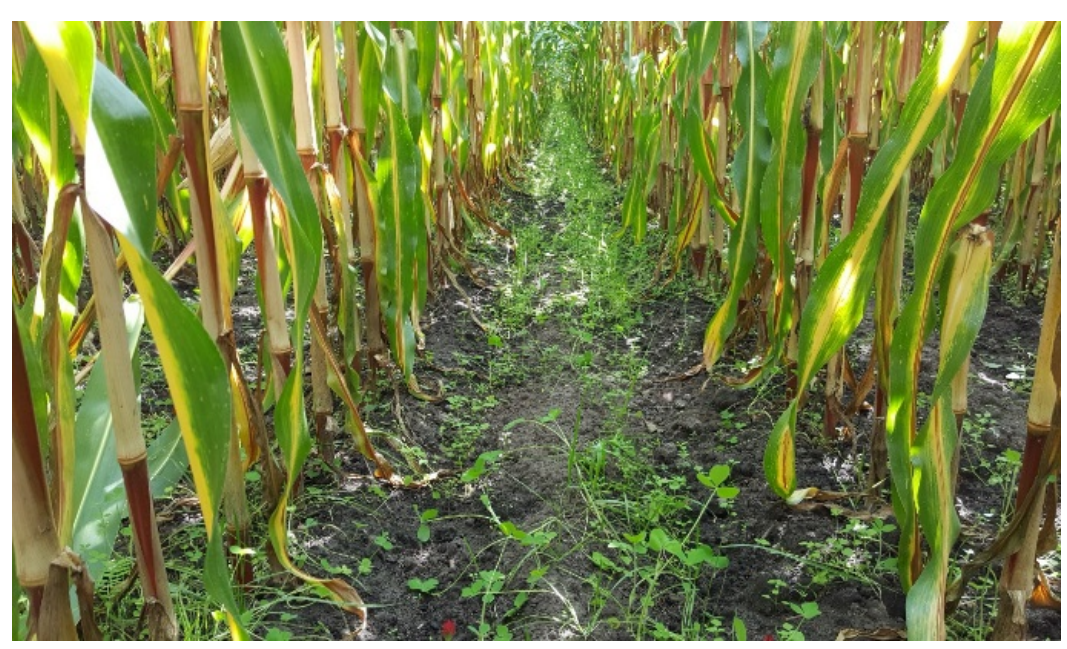

Onderzaai met Landsberger Gemenge

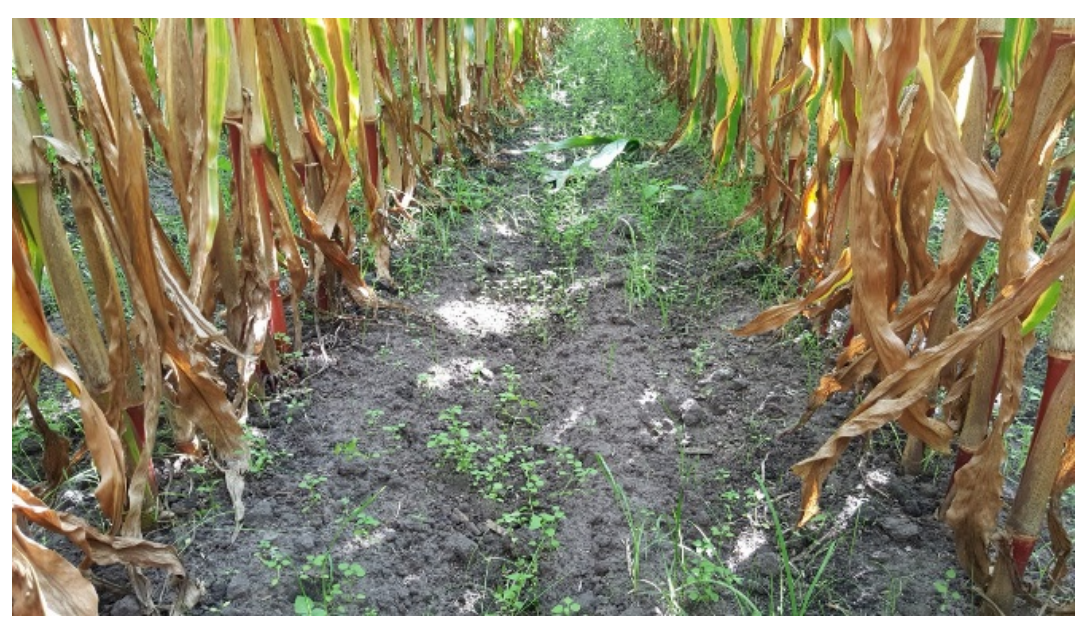

Onderzaai Italiaans Raaigras + rode klaver

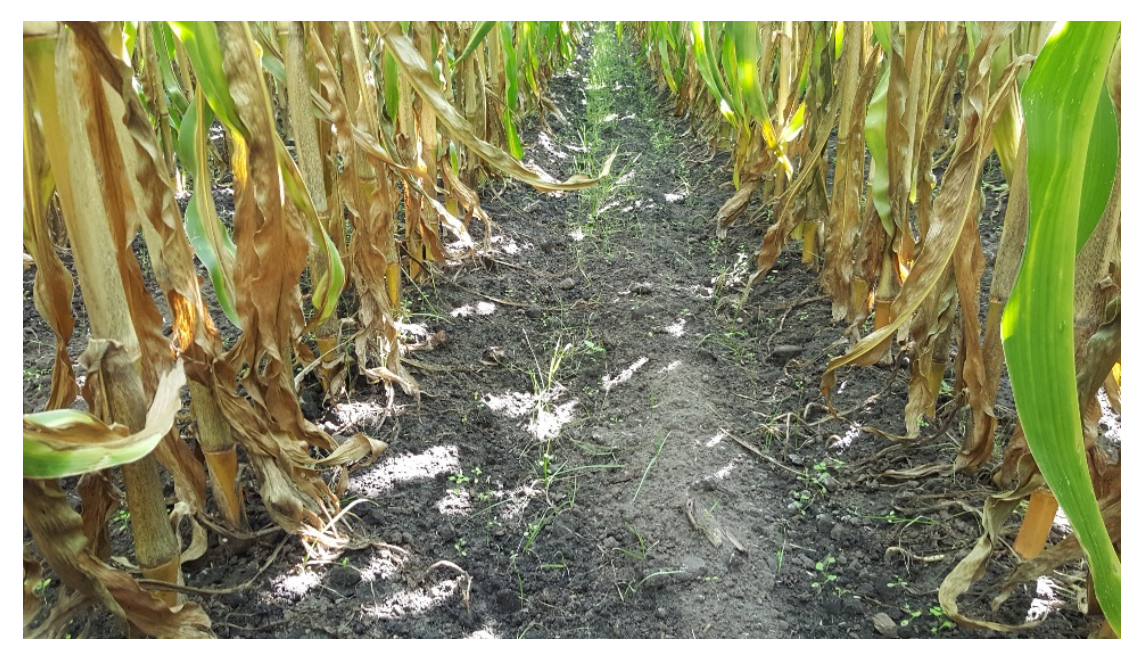

Onderzaai met Japanse Haver 


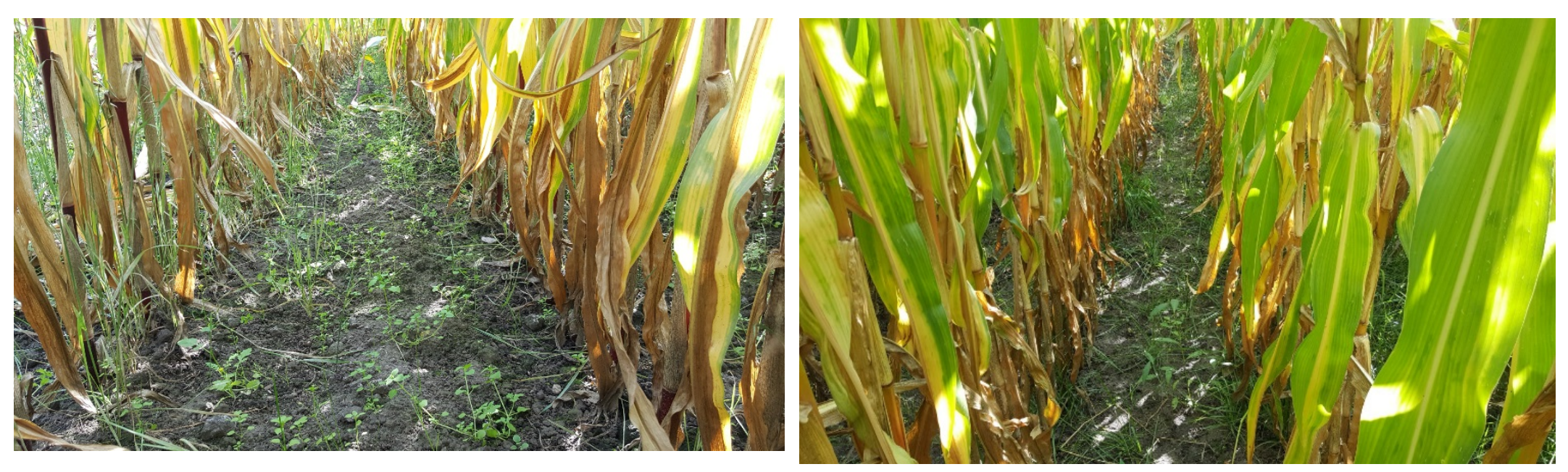

Onderzaai met Rietzwenkgras

Onderzaai met maisgras 
Tabel 16. Mais opbrengst gegevens satellietbedrijf Meijer.

\begin{tabular}{|c|c|c|c|c|c|c|c|}
\hline & $\begin{array}{l}\text { ton/ha } \\
\text { versopbrengst }\end{array}$ & $\begin{array}{l}\mathrm{g} \text { ds } / \mathrm{kg} \\
\text { vers }\end{array}$ & $\begin{array}{l}\text { ton } \\
\text { ds/ha }\end{array}$ & $\begin{array}{l}\text { per kg } \\
\text { VEM }\end{array}$ & $\begin{array}{l}\mathrm{g} / \mathrm{kg} \text { ds } \\
\text { Zetmeel }\end{array}$ & $\begin{array}{l}\text { ton/ha } \\
\text { zetmeelopbrengst }\end{array}$ & $\begin{array}{l}\text { kVEM/ha } \\
\text { VEM-opbrengst }\end{array}$ \\
\hline Autens & 38.6 & 415 & 16.0 & 986 & 401 & 6.4 & 15.8 \\
\hline autens+ myco & 43.0 & 428 & 18.4 & 1023 & 433 & 8.0 & 18.8 \\
\hline Benedicto & 44.6 & 379 & 16.9 & 1023 & 401 & 6.8 & 17.3 \\
\hline LG 31-205 & 42.4 & 389 & 16.5 & 1001 & 387 & 6.4 & 16.5 \\
\hline Megusto & 43.0 & 409 & 17.6 & 992 & 408 & 7.2 & 17.4 \\
\hline
\end{tabular}

Tabel 17. Nutriëntenafvoer met geoogst product

\begin{tabular}{|c|c|c|c|c|c|c|c|c|c|c|c|}
\hline & \multicolumn{6}{|c|}{ nutrientenafvoer $(\mathrm{kg} / \mathrm{ha})$} & \multicolumn{5}{|c|}{ Nutrienten afvoer (gram/ha) } \\
\hline & N/ha & $\mathrm{K}_{2} \mathrm{O}$ & $\mathrm{Mg}$ & $\mathrm{Ca}$ & P205 & $\mathrm{S}$ & $\mathrm{Cl}$ & $\mathrm{Mn}$ & $\mathrm{Zn}$ & $\mathrm{Fe}$ & $\mathrm{Cu}$ \\
\hline Autens & 146 & 220 & 19 & 26 & 59 & 13 & 24 & 256 & 400 & 1200 & 43 \\
\hline autens+ myco & 186 & 202 & 20 & 22 & 76 & 17 & 31 & 295 & 423 & 1086 & 48 \\
\hline Benedicto & 141 & 208 & 19 & 24 & 77 & 14 & 30 & 372 & 439 & 1165 & 42 \\
\hline LG 31-205 & 153 & 217 & 18 & 23 & 53 & 12 & 25 & 445 & 412 & 1287 & 53 \\
\hline Megusto & 166 & 216 & 21 & 23 & 72 & 14 & 39 & 316 & 492 & 1459 & 51 \\
\hline
\end{tabular}





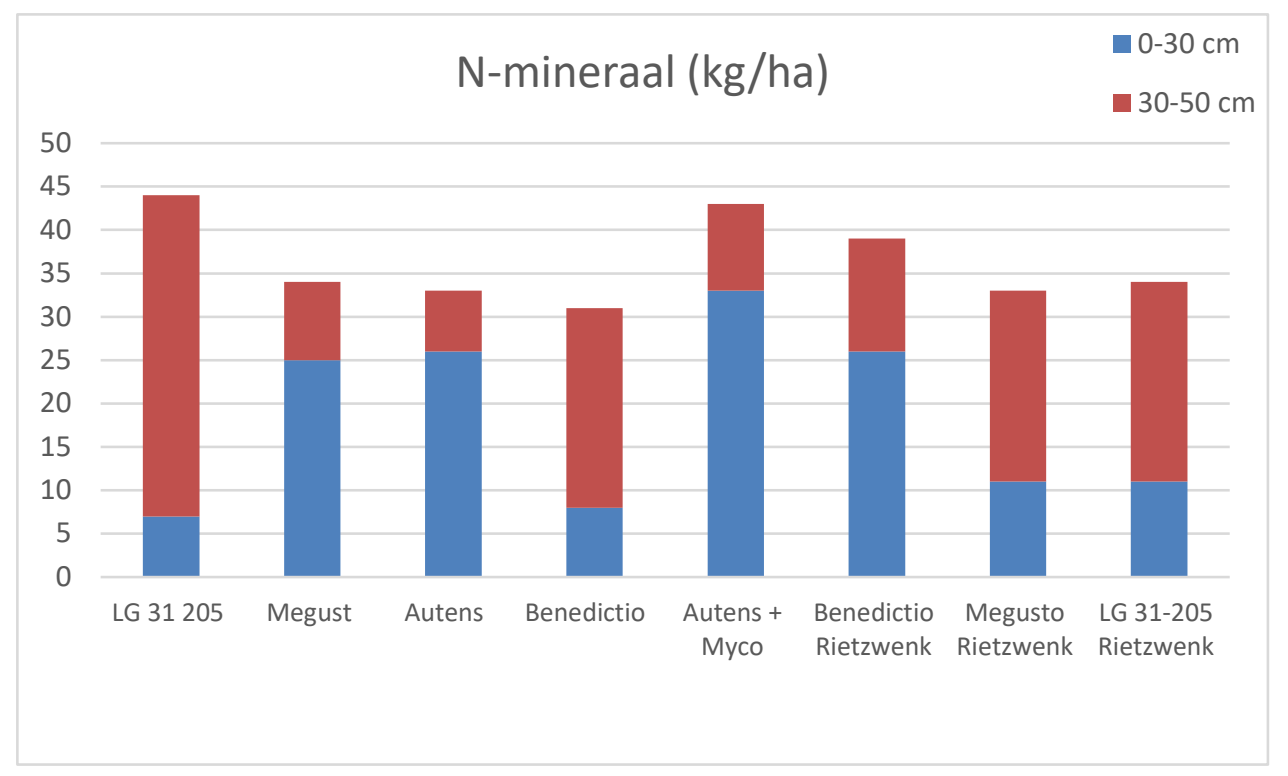

Figuur 36. Nmineraal metingen na oogst (12 oktober) 


\subsection{Tiems}

In 2018 is bij sattelietbedrijf $\mathrm{H}$. Tiems een demonstratie aangelegd met familie Tiems, G. Koops (Agrifirm), Menno Jansen (loonwerk; onderzaai) en Marie Wesseling/ Johan Specken (WUR OT). $\mathrm{Er}$ is geëxperimenteerd met het toepassen van het LDS-systeem. De onkruidbeheersing is uitgevoerd in twee afzonderlijke bespuitingen van 0,5 I/ha Calaris + 0.25 I/ha Samsung + 0.25 I/ha Kart. De bespuitingen zijn op 18 mei en 26 mei uitgevoerd.

Het oorspronkelijke plan bij Tiems omvatte ook het experimenteren met drijfmestgift in de rij versus een volvelds toepassing. Deze toepassing is echter afgezegd vanwege problemen met de injecteur.

\begin{tabular}{|c|c|c|c|c|c|c|c|c|}
\hline $\begin{array}{l}\frac{\mathrm{O}}{\mathrm{O}} \\
\mathrm{O}\end{array}$ & 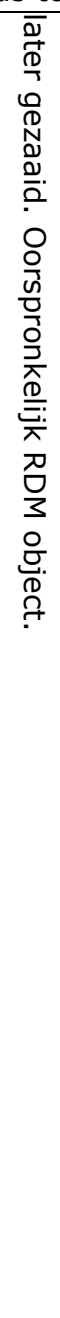 & 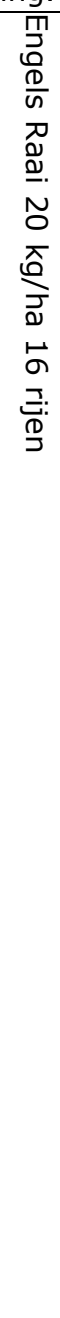 & 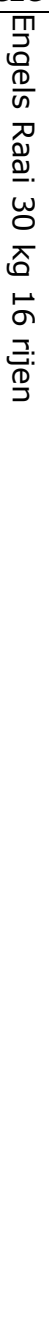 & 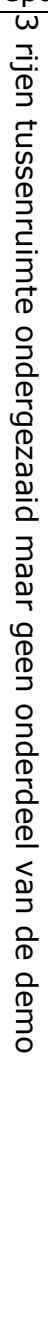 & 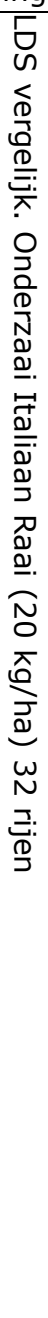 & 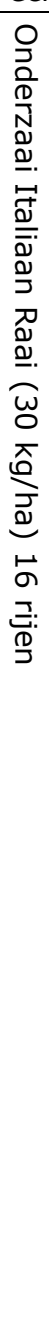 & 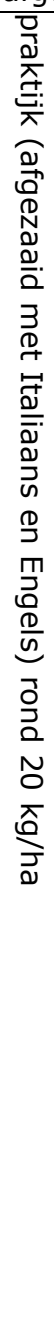 & $\begin{array}{l}\text { Verder is een vergelijking aangelegd met } \\
\text { zaaidichtheden van Engels- en Italiaans } \\
\text { raaigras. Deze zijn getoetst in doseringen } \\
\text { van } 20 \text { en } 30 \mathrm{~kg} / \mathrm{ha} \text {. De onderzaai is } 6 \text { juni } \\
\text { uitgevoerd. } \\
\text { Qua onkruidbestrijding was visueel geen } \\
\text { verschil zichtbaar tussen het deel van het } \\
\text { perceel dat eenmalig met } 1 \text { l/ha Calaris + } \\
0,5 \text { Milagro }+0.5 \text { Kart versus de strook } \\
\text { twee keer met een halve dosering is } \\
\text { gespoten. In beide gevallen was de mais } \\
\text { goed schoon. } \\
\text { Het groeiseizoen van } 2018 \text { was uitzonderlijk } \\
\text { droog en het was gemiddeld warmer dan in } \\
\text { andere zomers. Dit heeft geresulteerd in een } \\
\text { vroeg rijpend gewas. Het perceel is niet } \\
\text { beregend. De mais is bevatte een drogestof } \\
\text { van } 40 \% \text { met } 381 \mathrm{~g} / \mathrm{kg} \text { zetmeel en. Bij } \\
\text { afloop zijn } \mathrm{N} \text {-mineraal monsters genomen } \\
\text { uit de bodem om een indicatie te krijgen } \\
\text { hoeveel minerale stikstof er achter is } \\
\text { gebleven. Bij de bemonstering op } 19 \\
\text { september werd in de laag } 0-30 \mathrm{~cm} 48 \mathrm{~kg} \\
\mathrm{~N} / \text { ha aangetroffen terwijl er in de onderlaag } \\
\text { ( } 30-60 \mathrm{~cm} \text { ) } 84 \mathrm{~kg} \mathrm{~N} \text { mineraal werd } \\
\text { vastgesteld. Het droge jaar leidde tot een } \\
\text { matige ontwikkeling van het ondergezaaide } \\
\text { gras en na de oogst waren geen verschillen } \\
\text { zichtbaar in stand die dun was. }\end{array}$ \\
\hline
\end{tabular}




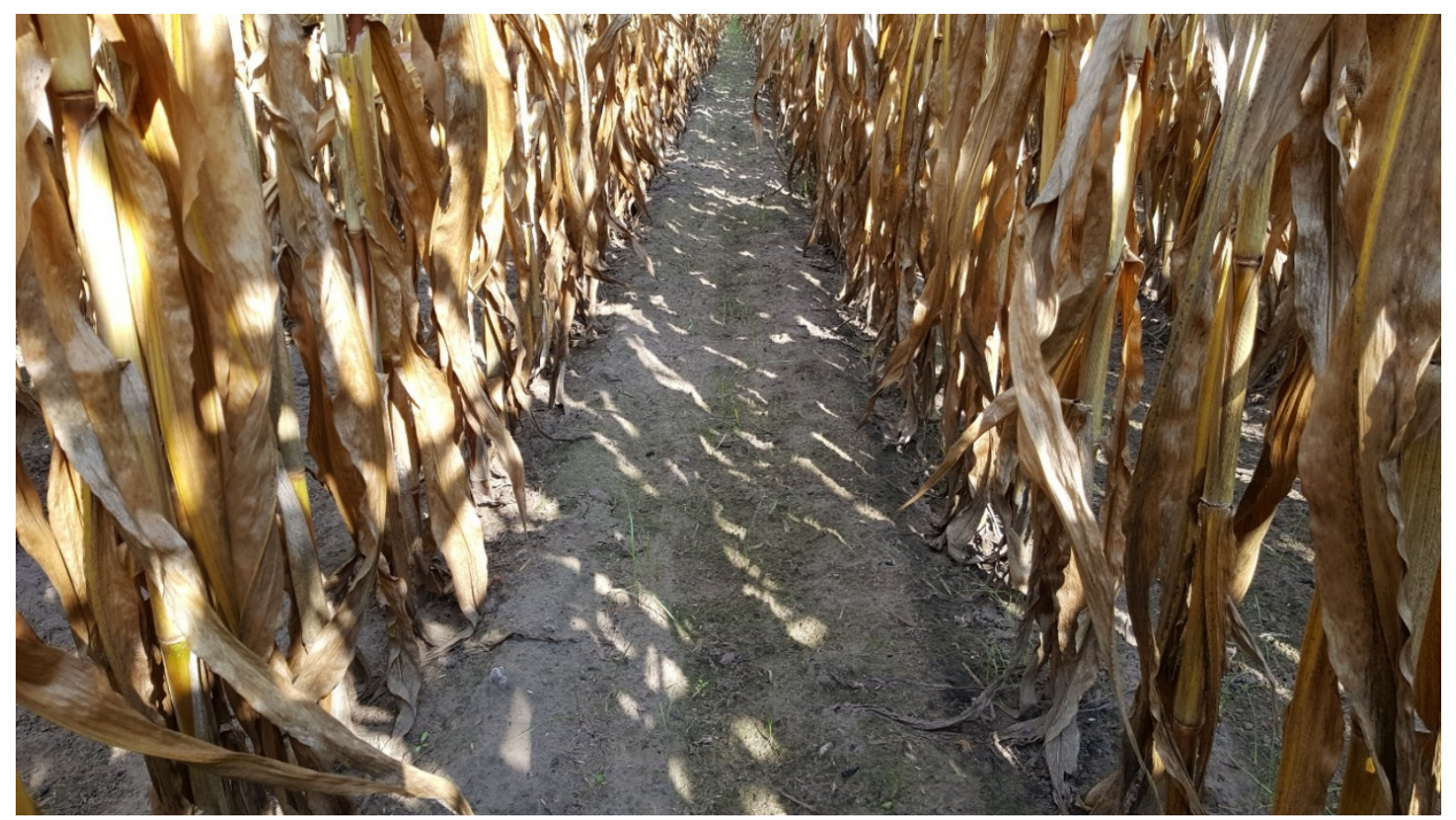

Stand demoveld qua onderzaai op 31 augustus kort voor de oogst. Er is nauwelijks onderzaai aanwezig op het perceel.

$\mathrm{N}$-mineraal bij afloop

\begin{tabular}{lr}
\hline monsteromschrijving & N-min \\
\hline laag $0-30$ & 84 \\
laag $30-60$ & 48 \\
N-min $0-60$ & $132 \mathrm{~kg} / \mathrm{ha}$ \\
\hline
\end{tabular}




\subsection{Smeenge}

Satellietbedrijf Mts Smeenge Hoofdweg 62 Zeegse

Teamsamenstelling: Jan Reinder Smeenge, Menno Jansen, H. Altena (Agro Noord), Marie Wesseling/ Johan Specken (WUR OT)

In 2018 is geëxperimenteerd met mest in de rij bij doseringen van 30, 35 en $40 \mathrm{~m}^{3} / \mathrm{ha}$. Daarnaast is een object aangelegd met een traag werkende $\mathrm{N}$-meststof die is aangeleverd via Agro Noord. De voorvrucht op het perceel was suikerbiet.

In het seizoen is er vanuit het waterschap Hunze en Aas gemonitord op de aanwezigheid van gewasbeschermingsmiddelen in het oppervlaktewater. Daarbij is het perceel aan de Linthorst Homanweg te Oudemolen bemonsterd. De resultaten hiervan zijn openbaar maar op dit moment nog niet gepubliceerd. De demo is aangelegd op een esgrond met een ruime bouwvoor. Hierdoor leek het gewas ondanks de droogte relatief goed groeien.

Opzet Maisdemo

\begin{tabular}{|l|c|r|}
\hline code & drijfmestrijengift & maismest in rij \\
\hline A & 30 & $40 \mathrm{~N} / \mathrm{ha}$ \\
\hline B & 35 & $40 \mathrm{~N} / \mathrm{ha}$ \\
\hline C & 40 & $40 \mathrm{~N} / \mathrm{ha}$ \\
\hline D & 40 & $40 \mathrm{~N} / \mathrm{ha}$ \\
\hline
\end{tabular}

Bij behandeling $\mathrm{D}$ is een vertraagde $\mathrm{N}$-meststof van Agro Noord getoetst.

In het seizoen is het perceel egaal ondergezaaid met $25 \mathrm{~kg} / \mathrm{ha}$ Italiaans raaigras. Een opbrengstbepaling is verricht op de hakselaar en er zijn monsters genomen waarin de voederwaarde van het geoogste mais is vastgesteld. Kort na het hakselen zijn uit de bodemlagen 0-30 en 30-60 cm grondmonsters verzameld waarin de $\mathrm{N}$-mineraal is vastgesteld.

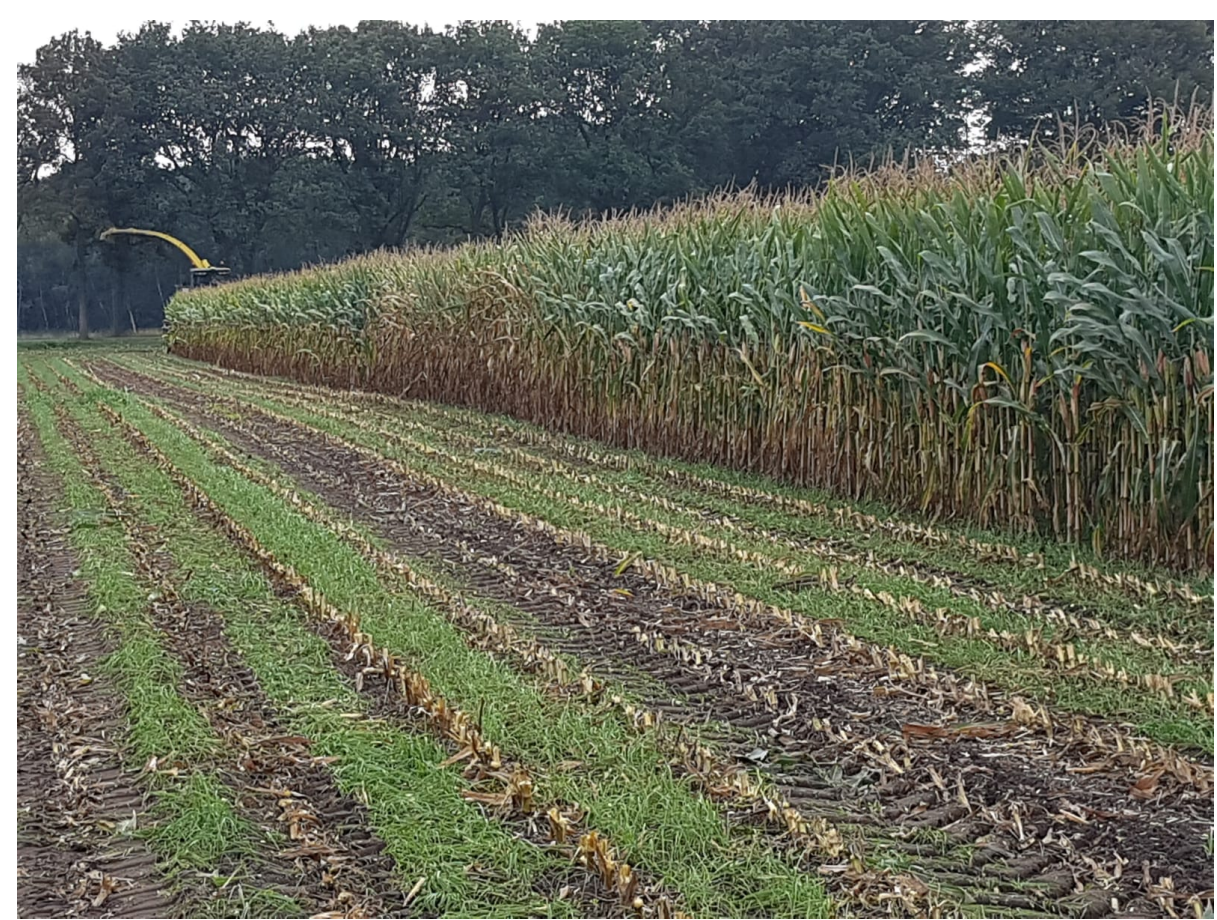

Figuur $x$. De stand van het gewas bij de oogst. Uit de afbeelding is zichtbaar dat de onderzaai met Italiaans raagras goed geslaagd was en dat de mais fors ontwikkeld was 


\begin{tabular}{|r|r|r|l|}
\hline $\mathrm{m}^{3} / \mathrm{ha}$ & \multicolumn{1}{l|l}{ ton/ha } & $\mathrm{g} / \mathrm{kg}$ ds & ton/ha \\
\hline RDM & ds & Zetmeel* & zetmeelopbrengst \\
\hline 30 & 10.5 & 375 & 3.9 \\
\hline 35 & 9.3 & 383 & 3.6 \\
\hline 40 & 8.7 & 449 & 3.9 \\
\hline
\end{tabular}

*Bepaald in het laboratorium

Uit bovenstaande blijk dat het verhogen van de RDM-gift resulteerde in een lagere drogestofopbrengst. De opbengstbepaling is verricht op de hakselaar en wijkt behoorlijk af ten opzichte van de geschatte opbrengst. Uit bovenstaande foto blijkt dat er een goed ontwikkelde mais stond op het perceel. De zetmeelgehalte is afkomstig van een bepaling die is verricht in het laboratorium. Daarnaast is er een trend zichtbaar waarbij het lijkt dat de hogere RDM-gift resulteert in een lagere opbrengst. Dit beeld was in het seizoen niet zichtbaar.

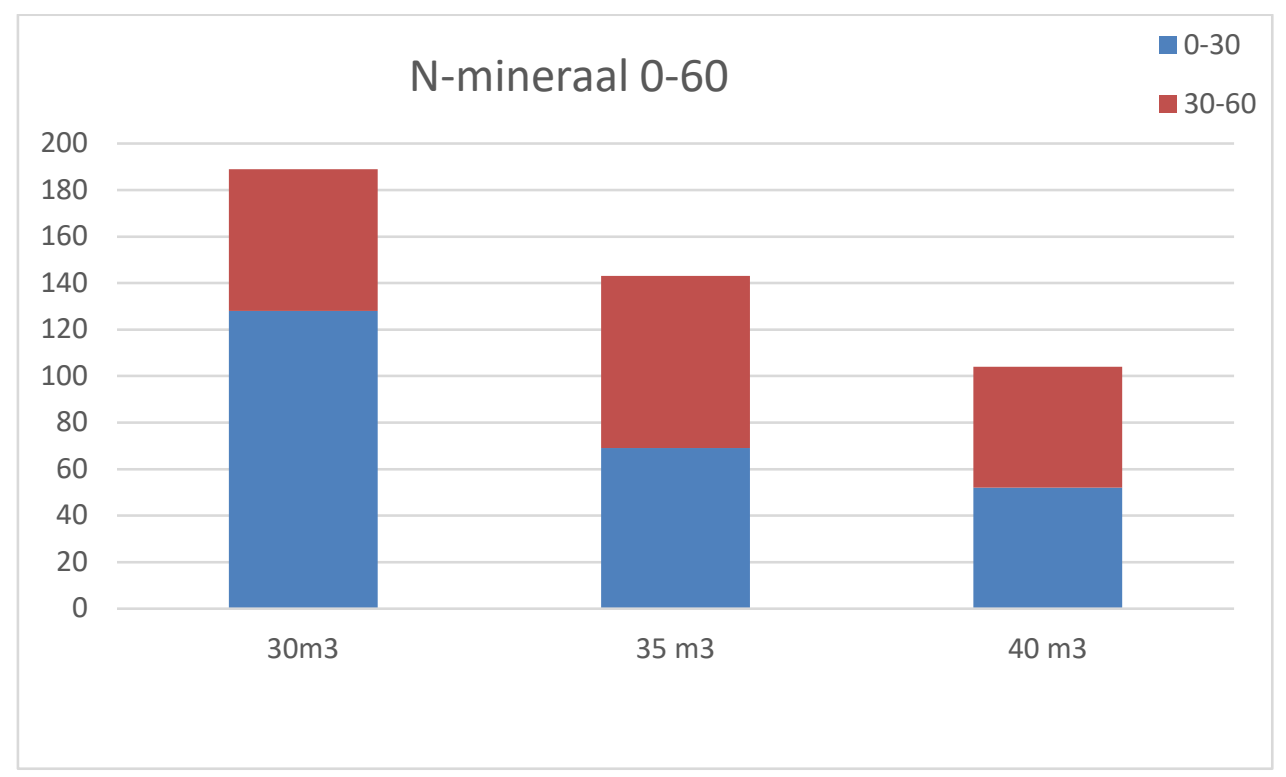

De hoeveelheid minerale stikstof in de bodem

Uit bovenstaande grafiek blijkt dat er duidelijke verschillen in de hoeveelheid N-mineraal zijn vastgesteld tussen de verschillende objecten. Opmerkelijke uitslag waarbij hogere giften resulteren in een lagere $\mathrm{N}$-mineraal. Verder opmerkelijk is dat er meer $\mathrm{N}$-mineraal werd gemeten dan er is toegediend met drijfmest en kunstmest in de rij bij het object met enkel 30m³ RDM. 


\section{Rassenonderzoek Ultravroege snijmais}

\subsection{Rassenonderzoek algemeen}

Het is wettelijk geregeld dat het rassenonderzoek uit twee onderdelen bestaat. Enerzijds het registratieonderzoek ( 2 jaar durend onderzoek voor registratie en kwekersrecht), waarbij gekeken wordt of een ras wel onderscheidbaar is van een ander ras, of het ras uniform genoeg is en of het ras van jaar tot jaar stabiel is. Dit onderzoek staat namens de overheid onder controle van de Raad van Plantenrassen (RvP) en wordt in Nederland uitbesteed aan Frankrijk. Dat kan omdat deze parameters niet afhankelijk zijn van de omstandigheden waaronder de maïs groeit.

$\mathrm{Bij}$ het tweede onderdeel de Cultuur- en Gebruikswaarde van rassen, waar gekeken wordt naar opbrengst, kwaliteit, ziektegevoeligheid en onkruid onderdrukkend vermogen, zijn de omstandigheden wel bepalend. Daarom moet dit onderzoek wel in Nederland worden uitgevoerd. In het specifieke geval van ultra vroege snijmaïsrassen, die met name voor Noord-Nederland van belang zijn, zijn de proeven dan ook in deze regio aangelegd.

Een ras moet in beide onderzoeken een goed resultaat laten zien, om opgenomen te worden op de Nationale Rassenlijst van Nederland en daarmee gelijk op de EU-lijst. Een ras mag dan in heel Europa verkocht worden.

Het Cultuur- en Gebruikswaarde onderzoek voor Ultra vroege snijmaïs wordt uitgevoerd door Wageningen University and Research - Praktijkonderzoek AGV volgens een door het RvP vastgesteld protocol. Jaarlijks worden de resultaten van de cultuur- en gebruikswaarde gepubliceerd in het Rassenbulletin "Ultra vroege Snijmaïs".

Voor een duurzame maïsteelt, waarbij gewerkt wordt aan optimale bodemkwaliteit, minimale uitspoeling, minimale ziektedruk en optimale output is aandacht voor het organische stofgehalte van de grond eerste vereiste. Verdere reductie van het organische stofgehalte kan met name voorkomen worden door optimale inzet van groenbemestingsgewassen of maïs in vruchtwisseling met gras. Voor optimaal resultaat van gras of groenbemester is een inzaai gedurende eerste helft september gewenst zo niet vereist. De groenbemester of het gras moet niet alleen organische stof leveren, maar bij de aangescherpte N- en P-gebruiksnormen ook stikstof, fosfaat, maar ook kali na leveren aan het volggewas maïs. Het landbouwkundig optimale stikstofadvies voor maïs ligt op $200 \mathrm{~kg} \mathrm{~N}$ minus Nmineraal, waar we tegenwoordig nog maar $140 \mathrm{~kg} \mathrm{~N}$ mogen geven en straks in Zuid Nederland nog slechts rond de $110 \mathrm{~kg}$ stikstof. Inzet van groenbemesters moet in de toekomst dan ook gezien worden als een vast onderdeel van de teelt, conform onkruidbestrijding. Waar het in huidige maïsteelt vaak nog gezien wordt als wettelijk verplichte kostenpost, die niets oplevert.

In Noord Nederland wordt de maïs veelal gezaaid rond 1 mei, omdat dan de bodemtemperatuur overeenkomt met de minimum kiemtemperatuur van maïs van rond de $10{ }^{\circ} \mathrm{C}$. Voor een duurzame maïsteelt in Noord-Nederland moet geoogst worden vóór 15 september. Dat betekent een groeiseizoen van 18 tot 20 weken.

Aan de andere kant is het streven de maïs te oogsten bij 32-38\% drogestof met een hoge opbrengst en kwaliteit. Een minimaal drogestofgehalte van $28 \%$ is vereist, om inkuilverliezen te beperken. Optimum drogestofgehalte is $34-36 \%$ drogestof. De ultra vroege snijmaïs geeft ook meer mogelijkheden voor maïs-gras vruchtwisseling. Zo kan in mei nog een grassnede worden geoogst, bij een zaai rond 1 juni is de maïs rond 15 oktober rijp.

Onderstaande tabel uit "PPO-Rassenbulletin Ultra vroege snijmaïs" is een weergave van de resultaten (2013 t/m 2018), waarbij de maïs een groeiseizoen heeft gekregen van 20 weken. 


\subsection{Rassenbulletin ultravroege snijmais}

Tabel 18. Rassenbulletin ultravroege snijmais 2019. Gemiddelde resultaten over 2013 t/m 2018.

\begin{tabular}{|c|c|c|c|c|c|c|c|c|c|c|c|c|c|c|c|c|c|c|c|}
\hline $\operatorname{Ras}^{1)}$ & 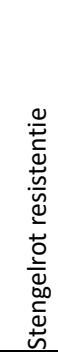 & 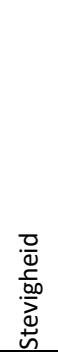 & 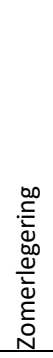 & 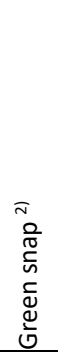 & 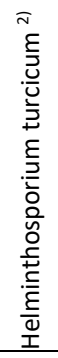 & $\frac{\stackrel{+}{\circ}}{\stackrel{0}{0}}$ & 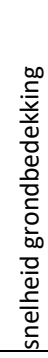 & 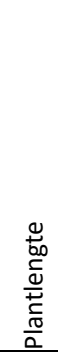 & $\begin{array}{l}\overline{0} \\
0 \\
0 \\
\overline{0} \\
\overline{0} \\
\frac{0}{00} \\
0 \\
0 \\
\frac{0}{>}\end{array}$ & 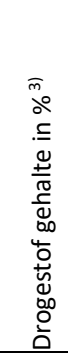 & 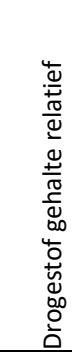 & 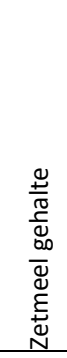 & $\begin{array}{l}\frac{D}{ \pm} \\
\frac{ \pm}{0} \\
\frac{1}{0} \\
\frac{0}{0} \\
\frac{0}{1} \\
\frac{\pi}{3} \\
\frac{3}{U}\end{array}$ & 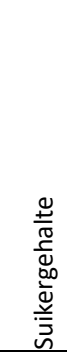 & 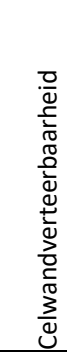 & 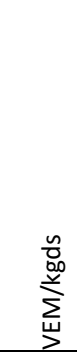 & 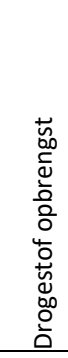 & 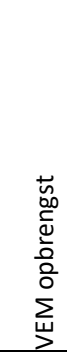 & 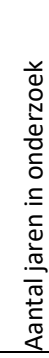 \\
\hline \multicolumn{20}{|l|}{$\begin{array}{l}\text { Meerjarig } \\
\text { onderzocht }\end{array}$} \\
\hline Emmerson & 6 & 7.5 & 8.5 & 8 & 7 & 7.5 & 7.5 & 97 & 8.5 & 38.2 & 104 & 102 & 101 & 91 & 100 & 100 & 92 & 92 & 4 \\
\hline Activate-12 & 6 & 7.5 & 8 & 8 & 8 & 7.5 & 8 & 98 & 8 & 37.5 & 102 & 103 & 97 & 95 & 100 & 100 & 101 & 101 & 6 \\
\hline Prospect & 8.5 & 7 & 7.5 & $*$ & $*$ & $*$ & 7.5 & 100 & 8 & 36.7 & 100 & 100 & 99 & 108 & 100 & 101 & 106 & 107 & 2 \\
\hline Ambition & 8.5 & 8 & 9 & 7.5 & 8.5 & 8 & 7 & 104 & 7.5 & 35.9 & 98 & 97 & 102 & 109 & 99 & 99 & 103 & 103 & 6 \\
\hline Asgaard & 8 & 8 & 9 & 8 & 8 & 8 & 6.5 & 101 & 7.5 & 35.2 & 96 & 99 & 101 & 105 & 102 & 101 & 104 & 105 & 5 \\
\hline Actual & 6.5 & 6.5 & 6 & $*$ & 8.5 & 7 & 7.5 & 100 & 7 & 34.5 & 94 & 97 & 103 & 104 & 100 & 100 & 106 & 105 & 3 \\
\hline \multicolumn{20}{|l|}{$\begin{array}{l}1 \text { jaar } \\
\text { onderzocht }\end{array}$} \\
\hline X70N194 & 7 & 6.5 & $*$ & $*$ & $*$ & $*$ & 9 & 104 & 7 & 37.1 & 101 & 91 & 107 & 101 & 91 & 96 & 94 & 90 & 1 \\
\hline Autens KWS & 7 & 6.5 & $*$ & $*$ & $*$ & $*$ & 8.5 & 108 & 7.5 & 35.8 & 97 & 97 & 105 & 92 & 101 & 98 & 105 & 103 & 1 \\
\hline KXB7313 & 7.5 & 8.5 & $*$ & $*$ & $*$ & $*$ & 8.5 & 105 & 7 & 34.2 & 93 & 97 & 97 & 125 & 99 & 101 & 112 & 114 & 1 \\
\hline DKC2978 & 8 & 8.5 & $*$ & $*$ & $*$ & $*$ & 6.5 & 106 & 6.5 & 33.6 & 91 & 99 & 99 & 110 & 101 & 101 & 108 & 109 & 1 \\
\hline Amaizi CS & 7.5 & 6.5 & $*$ & $*$ & $*$ & $*$ & 8 & 105 & 6.5 & 33.5 & 91 & 84 & 110 & 138 & 99 & 99 & 99 & 98 & 1 \\
\hline Sufaster & 7.5 & 6.5 & $*$ & $*$ & $*$ & $*$ & 7.5 & 97 & 7 & 32.5 & 89 & 97 & 100 & 126 & 102 & 101 & 104 & 105 & 1 \\
\hline Likeit & 7.5 & 7 & $*$ & $*$ & $*$ & $*$ & 8.5 & 107 & 7 & 32.4 & 88 & 90 & 106 & 122 & 96 & 98 & 103 & 100 & 1 \\
\hline \multicolumn{8}{|c|}{$\begin{array}{l}100=\text { (Ambition, Activate, Asgaard, Emmerson) } \\
\text { resp. in cm; \%; gr/kgds; gr/kgds; \%; VEM/kgds; ton/ha; } \\
\text { ton kVEM/ha }\end{array}$} & 265 & & & 36.7 & 404 & 351 & 64.9 & 54 & 1016 & 18.1 & 18.4 & \\
\hline
\end{tabular}

* Onvoldoende resultaten bekend

1) Rassen gerangschikt op volgorde van vroegheid; Standaard $100.000 \mathrm{pl} / \mathrm{ha}$; Achter rasnaam -12 is $120.000 \mathrm{pl} / \mathrm{ha}$;

2) Green snap alleen gebaseerd op de resultaten van 2015; Helminthosporium alleen gebaseerd op 2016

3) 3\% verschil in drogestofgehalte betekent ongeveer 1 week vroeger

Streven ultra vroege snijmais in Noord-Nederland: zaai 1 mei en oogst vóór 15 september; minimaal vereist ds-gehalte is 32.07\%

Zaai en Oogstdatum 2018- Oudemirdum 2/5 - 1/9 en Rolde 28/4 - 3/9. 


\section{Activiteiten en communicatie 2018}

\subsection{Activiteiten}

Winterbijeenkomsten

Op 8 februari 2018 vond de winterbijeenkomst over het teeltseizoen van 2017 plaats. Op 6 februari 2019 vond de winterbijeenkomst plaats waarin de resultaten van het seizoen 2018 besproken werden. Ook werd er vooruitgekeken naar 2019. Bij deze bijeenkomst waren ongeveer 30 bezoekers.

Onderzaai demonstratie

In samenwerking met Agrifirm is op 5 juni een onderzaai demonstratie georganiseerd. Deze onderzaaidemo werd in de omgeving van Westerbork gehouden op een praktijkperceel van een melkveehouder. Tijdens deze avond werd er stilgestaan bij het hoe en waarom van onderzaai, en konden verschillende loonwerkers hun machines demonstreren stellen. Deze bijeenkomst werd goed bezocht met ruim 80 bezoekers.

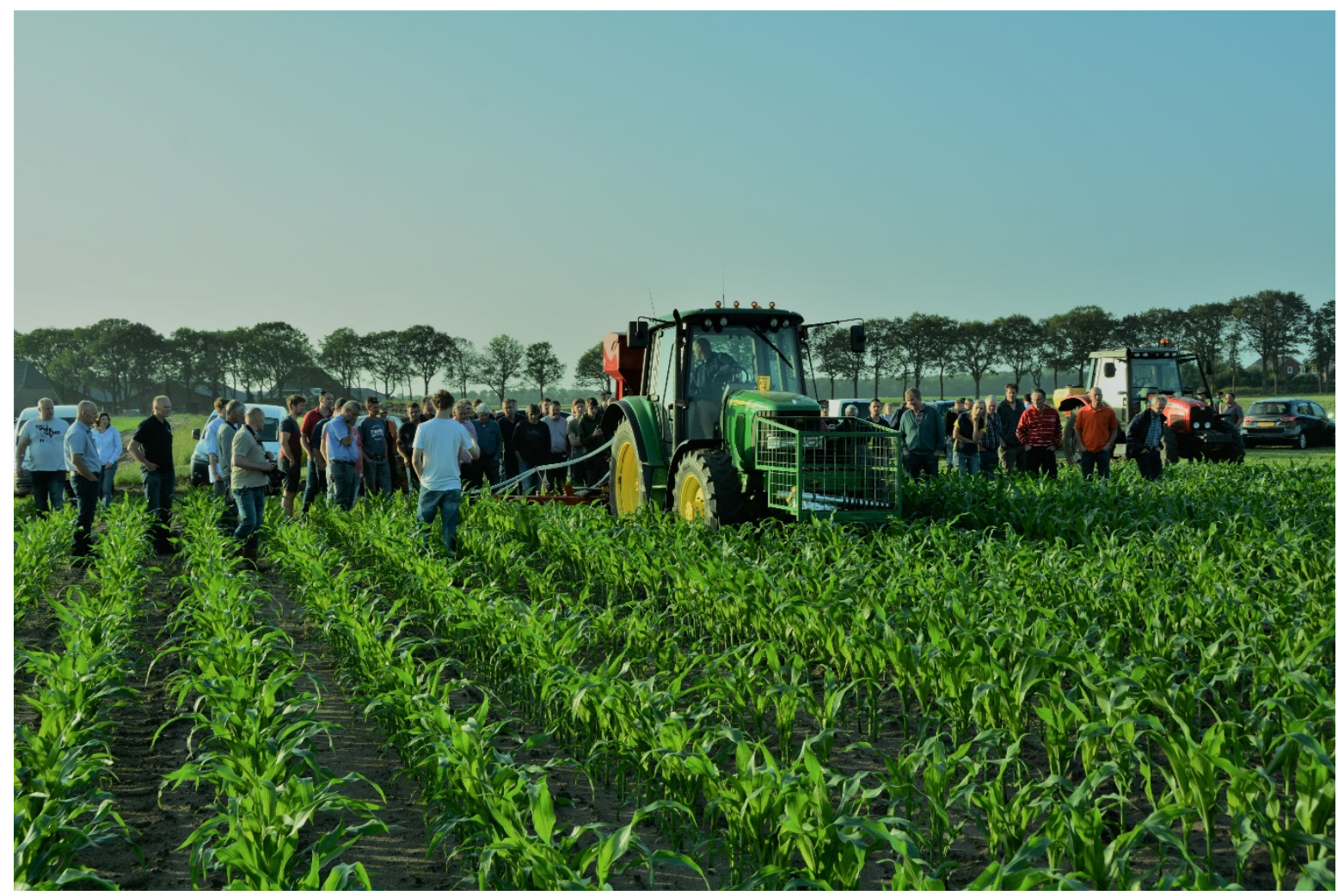

Figuur 37. Onderzaai demonstratie op 5 juni 2018.

Rondgang in het seizoen (17 juli)

Op 17 juli werd er een rondgang georganiseerd waarbij de stand van de mais en de onderzaai op verschillende satellietbedrijven is bekeken. In de middag is een bezoek gebracht aan het drinkwaterbedrijf in de Punt waar we een rondleiding kregen en in gesprek gingen over vervuiling van het water met gewasbeschermingsmiddelen.

Veldbijeenkomsten satellietbedrijven

Op verschillende satellietbedrijven zijn in het seizoen bijeenkomsten georganiseerd waar bezoekers de verschillende demonstraties konden bekijken en erover in gesprek gingen. 
Gras en Mais Manifestatie 28 augustus

Op 28 augustus werd in samenwerking met Agrifirm de Gras en Mais Manifestatie georganiseerd bij WUR Open Teelten te Marwijksoord. Gedurende de zomermaanden werd besloten de manifestatie naar voren te halen, vanwege het snelle afrijpen van de mais door de extreme weersomstandigheden. Desondanks werd de manifestatie goed bezocht met circa 120 bezoekers. Er werd stilgestaan bij het actuele thema van dat moment: droogte. Zo was er onder andere aandacht voor het belang van goed bodembeheer om bestand te zijn tegen zowel droogte als wateroverlast.

Vanggewasmiddag 22 november

In samenwerking met Agrifirm en CUMELA werd op 22 november een thema middag gehouden in Marwijksoord. De dag werd met ongeveer 75 bezoekers goed bezocht. Thema van middag was de aankomende verplichtingen omtrent het vanggewas uit het $6^{\mathrm{e}}$ Actieprogramma Nitraat. Na een uiteenzetting van de regels waarmee we te maken krijgen werd er een bezoek gebracht aan de vanggewas demonstraties in het veld.

Hiernaast zijn er verscheidene lezingen gegeven voor loonwerkers, adviseurs en boeren, en zijn er excursies georganiseerd langs de demovelden.

\subsection{Communicatie}

De website www.grondigboerenmetmais.nl is onderhouden en wordt regelmatig aangevuld met nieuwe resultaten van de verschillende demonstraties.

Via mailchimp worden er verscheidene nieuwsbrieven gestuurd naar volgers van Grondig boeren met Mais. Dit zijn er in Drenthe ruim 400. Deze nieuwsbrieven bevatten het laatste nieuws rondom de demonstraties en aankondigingen voor bijeenkomsten.

Hiernaast zijn er een aantal artikelen verschenen:

- 11 januari 2018 - Nieuwe Oogst - "WUR heeft optimale groenbemester nog niet gevonden" https://www.nieuweoogst.nu/nieuws/2018/01/11/wur-heeft-optimale-groenbemester-nogniet-gevonden

- 10 februari 2018 - Nieuwe Oogst - "Meer organische stof werkt positief in bodem"

- 5 september 2018 - Boerderij - "Organische stof centraal in maisteelt" https://www.boerderij.nl/Rundveehouderij/Achtergrond/2018/9/Organische-stof-centraal-inmaisteelt-330153E/

- Januari 2019 - Grondig - " Als volwaardige teelt behandelen"

- Juli 2018 - Grondig - "Groenbemester belangrijk voor plant en milieu"

- Juli 2018 - Melkvee - Experimenteren met maisteelt zonder mest

- December 2018 - Stal \& Akker - Vanggewas na mais blijft moeilijk

- September 2018 - Grondig nieuwsbrief - Vanggewas na mais

- November 2018 - Grondig nieuwsbrief - Meeste mais na 1 oktober geoogst

- November 2018 - Groenbemester met slechtste stand meeste biomassa

- December 2018 - Boerderij, Rundveehouderij | Maisteelt 2019, 11 dec. 18 | nr. 11 | Wet maakt maisteelt op zand uitdaging 
Grondig boeren met mais is een meerjarig project met als doel om de maisteelt te verduurzamen. Het project heeft in de afgelopen jaren met grote regelmaat centraal gestaan in bijeenkomsten en lezingen. Hierbij is kennis overgedragen die is vergaard in het project met betrekking tot onderzaai, teeltwijze en bodembeheer.

\subsection{Optreden en verspreiding probleemgrassen}

In de systemendemo heeft in de afgelopen jaren een sterke toename van gladvingergras Digitaria ischaemum plaatsgevonden. Inmiddels (in de afgelopen 7 jaar) heeft zich dit gras dusdanig sterk vermeerderd dat het een serieuze concurrentie is geworden van het hoofdgewas. Dit grasonkruid blijkt lastig te bestrijden met de beschikbare grassenmiddelen wanneer we willen onderzaaien.

Bodemherbicides kunnen niet of slechts in beperkte mate ingezet worden in combinatie met onderzaai in het 6-8 bladstadium. In de voortzetting van het project zal er meer nadruk op het beheersen van dit onkruid worden gelegd. Dit trachten we te doen door het toevoegen van een mechanische onkruidbestrijding.

Ook vanuit de praktijk worden meldingen gedaan van lastig beheersbare grassen in de teelt van snijmais. Met name in combinatie met onderzaai is de beheersbaarheid van deze onkruiden lastiger. Naar de toekomst toe mag worden aangenomen dat de druk van probleemonkruiden zoals gladvingergras en hun bestrijdbaarheid medebepalend zullen worden voor de wijze waarop de mais geteeld zal worden.

\subsection{Optreden ziekte}

In de afgelopen jaren heeft zich een ziektebeeld ontwikkeld bij kiemplanten worden aangetast. De betroffen planten kleuren bleek weg en blijven achter in de groei. Dit beeld lijkt zich vooral in de systemen praktijk, extra organische stof en in de demo waar de mineralen uit kringloop worden toegepast. In de afgelopen jaren is gezocht naar de oorzaak van dit patroon waarbij de nutrientenstatus, de analyse op plant parasitaire aaltjes en een DNA-multiscan is uitgevoerd. Hieruit bleek geen conclusie getrokken te kunnen worden. In 2018 is kort na opkomst ziek plantmateriaal uitgegraven en aangeboden aan de NVWA voor visuele diagnose. Door de PD werd op basis van visuele diagnose Rhizoctonia Spp. geconstateerd.

Ook lijkt er een trend zichtbaar tussen de manier van bodemgebruik en de mate waarin de ziekte optreedt. In het gangbare object is er een sterkere ziektedruk aanwezig dan in de objecten met extra organische stof en het object met mineralen uit kringloop. Mogelijk dat er een verband is tussen bodembeheer en het optreden van de ziekte. Dit moet verder uitgezocht worden.

\subsection{Bodemvruchtbaarheid op termijn}

Om het effect van de verschillende systemen op de bodemparameters in beeld te brengen, zijn in 2014 en in 2018 bodemmonsters gestoken. Hieruit blijkt dat er geen structurele veranderingen in de meeste bodemparameters zijn vastgesteld. Het organische stofgehalte in de bodem is niet meetbaar veranderd bij het standaard systeem en het systeem met extra organische stof aanvoer. Ook in theorie is het verhogen van het organische stofgehalte in de bodem met bijvoorbeeld één procent niet haalbaar met de aanvoerhoeveelheden aan organisch materiaal. Bij bodemvruchtbaarheid op termijn moet vooral gedacht worden aan het aanvoeren van vers organische materiaal. Dit verhoogt de biologische activiteit in de bodem, de afbraak ervan levert nutriënten en draagt bij aan een gezondere weerbare bodem. 


\section{Conclusies}

Het is belangrijk te realiseren dat Grondig boeren met maïs gericht is op het onder de aandacht brengen van duurzame teeltsystemen van maïs middels kennis overdracht en demonstratie. Bij de demonstratie (systeem-, detail demonstraties en op satellietbedrijven) worden diverse metingen uitgevoerd. Omdat de demonstraties niet in meervoud uitgevoerd zijn is het niet mogelijk om harde conclusies te trekken. Naarmate de systeemdemonstratie langer loopt krijgen gemiddelde cijfers meer waarde en kan een trend waargenomen worden.

\subsection{Systemendemonstratie}

Qua maisopbrengst liggen de verschillende systemen in lijn met de resultaten van de afgelopen jaren. De systemen organische stof en mineralen uit kringloop laten een stijgende lijn zien, relatief ten opzichte van het standaard systeem. Het vruchtwisseling systeem laat een nog positievere lijn zien, terwijl het twee oogsten systeem wisselend presteert over de jaren.

Ten opzichte van het standaard systeem heeft het organische stofsysteem een positievere stikstof-, fosfaat-, en organische stofbalans. Het mineralen uit kringloop systeem heeft een lager stikstofoverschot en een vergelijkbare fosfaat- en organische stofbalans als standaard. Het twee oogsten systeem presteert qua nutriëntenbalansen vergelijkbaar met standaard, maar heeft een positievere organische stofbalans. Het vruchtwisseling systeem presteert in de maisteelt vergelijkbaar met standaard, in de grasteelt is vooral de organische stofbalans vele malen positiever, zodat de balans gemiddeld op systeemniveau zeer positief is.

Het berekende saldo per hectare van de maisteeltsystemen is sterk onder invloed van de opbrengst. Gemiddeld over de jaren verdwijnt deze variatie en zijn de verschillen minimaal. Het standaard systeem heeft gemiddeld de laagste kosten, het mineralen uit kringloop de hoogste, het verschil is slechts 22 euro. Ook qua saldo zijn de systemen vergelijkbaar, alleen het twee oogsten systeem blijft hierin wat achter door de wisselende en tegenvallende maisopbrengsten.

Door het achterwege laten van bodemherbiciden (in verband met de gras onderzaai) wordt een sterke verlaging van de milieubelastingspunten gerealiseerd. Uit de detaildemo onkruidbeheersing in relatie tot onderzaai kwam ook in 2018 naar voren dat het goed mogelijk is om een schoon maïsgewas te telen zonder inzet van de bodemherbiciden, met de kanttekening dat er geen probleemonkruiden zoals gladvingergras of hanepoot aanwezig zijn.

\subsection{Detaildemonstraties}

Een nadeel van een goed ontwikkeld vanggewas is het inwerken hiervan in het voorjaar, wanneer deze massaal ontwikkeld is. In de praktijk past men vaak Roundup (glyfosaat) toe om het gras dood te spuiten. In de onderwerk detaildemo bleek het nog niet heel eenvoudig om een vanggewas zonder glyfosaat onder te werken. Van alle aangelegde behandelingen bleek vooral het frezen een gewenst effect te hebben.

Zoals aangegeven was het ook in 2018 prima mogelijk om de mais onkruidvrij te houden zonder het gebruik van bodemherbicides. Het gebruik van bodemherbicides had een zichtbaar negatief effect op de onderzaai. Ook een volle dosering versus een LDS systeem had zichtbaar effect op de onderzaai. 
Om het onderwerken van het vanggewas te vergemakkelijken wordt er gekeken naar alternatieve vanggewassen. De rode en Perzische klaver zijn in 2018 niet tot matig ontwikkeld. In combinatie met gras deed de rode klaver het iets beter.

\subsection{Satellietbedrijven}

De satellietbedrijven hebben in 2018 vooral thema's opgepakt om de maisteelt te verduurzamen die relevant zijn voor hun eigen bedrijf/ regio. Iedereen deed vooruitlopend aan de regelgeving mbt onderzaai die in 2019 van start gaat aan onderzaai en een aantal experimenteerden hiermee. Men is op zoek naar onderzaai gewassen die gemakkelijk onder te werken zijn en het liefst zonder inzet van chemie. Ook het thema biodiversiteit is een belangrijk aspect bij onderzaai waarbij men kijkt naar mengsels met het liefst bloeiende groenbemesters. Bij de verschillende satellietbedrijven zijn in de afgelopen jaren diverse andere vraagstukken behandeld, onder andere het toepasen van drijfmest in de rij. Een ander aspect van onderzaai waar men mogelijk tegen aan loopt is de manier van onderwerken.

\section{$8.4 \quad$ Overall}

Uit de resultaten van de afgelopen zeven jaar komt naar voren dat alternatieve teeltsystemen bijdragen aan een verbeterde bodemkwaliteit. Investeren in de bodem kost tijd, maar komt in dit geval na enkele jaren wel tot uiting in de opbrengst en het saldo. Aanvoer van extra organische stof of het toepassing van vruchtwisseling loont. De praktijk ziet steeds meer het belang van aandacht voor de bodem en geslaagde groenbemesters, toepassing van maatregelen neemt langzaam toe. De satellietbedrijven vormen de voelsprieten in de provincie en een mooi platform om onderdelen uit het project aan maïstelers uit de buurt te laten zien. 
$9 \quad$ Bijlages

\subsection{Droge stof opbrengsten per hectare per systeem voor de jaren 2012-2018}

\begin{tabular}{|c|c|c|c|c|c|c|c|}
\hline Systeem & 2012 & 2013 & 2014 & 2015 & 2016 & 2017 & 2018 \\
\hline Gangbaar & 14.7 & 15.2 & 16.2 & 13.5 & 15.4 & 15.0 & 13.5 \\
\hline Org. stof & 14.2 & 13.8 & 13.8 & 14 & 16.8 & 16.3 & 17.5 \\
\hline Mineralen & 13.4 & 13.7 & 16.2 & 11.3 & 17.6 & 15.2 & 17.4 \\
\hline $\begin{array}{l}\text { Twee oogsten } \\
\text { mais }\end{array}$ & 12.9 & 11.1 & 14.4 & 6.6 & 15.0 & 13.3 & 11.1 \\
\hline $\begin{array}{l}\text { Twee oogsten } \\
\text { mais+gras }\end{array}$ & & 13.1 & 16.8 & 8.2 & 20.1 & 16.0 & 13.0 \\
\hline Vruchtwisseling & & & & 10.4 & 18.1 & 20.7 & 17.9 \\
\hline
\end{tabular}

\subsection{Berekening mineralenbalans 2018}

Tabel 19. Hoeveelheid, toediening en gehaltes van toegepaste meststoffen per systeem voor 2018.

\begin{tabular}{|c|c|c|c|c|c|c|c|}
\hline Systeem & rij/volvelds & mestsoort & $\mathrm{m}^{3}$ of $\mathrm{kg} / \mathrm{ha}$ & $\mathrm{N}-\mathrm{m}$ & $\mathrm{N}$-org & P205 & $\mathrm{K} 20$ \\
\hline \multirow[t]{3}{*}{1 Gangbaar } & volvelds & RDM & 35 & 2.1 & 2.0 & 0.82 & 4.69 \\
\hline & Rij & KAS & 220 & 27 & & & \\
\hline & Volvelds & $K-60$ & 100 & & & & 60 \\
\hline \multirow[t]{4}{*}{2 Organische stof } & Volvelds & RDM & 15 & 2.1 & 2.0 & 0.82 & 4.69 \\
\hline & volvelds & Groen compost & 20 & 0.8 & 7 & 4.3 & 6.4 \\
\hline & Volvelds & $K-60$ & 50 & & & & 60 \\
\hline & rij & KAS & 210 & 27 & & & \\
\hline \multirow[t]{3}{*}{3 Kringloop } & rij & Dunne fractie & 50 & 1.7 & 1.8 & 1.21 & 4.3 \\
\hline & Volvelds & $\mathrm{K}-60$ & 75 & & & & 60 \\
\hline & & KAS & 0 & & & & \\
\hline \multirow[t]{4}{*}{42 oogsten } & Volvelds & RDM - zode & 20 & 2 & 1.9 & 1.15 & 2 \\
\hline & $\mathrm{Rij}$ & RDM - mais & 20 & 2.1 & 2.0 & 0.82 & 4.69 \\
\hline & Rij & KAS & 100 & 27 & & & \\
\hline & Volvelds & $\mathrm{K}-60$ & 100 & & & & 60 \\
\hline \multirow[t]{3}{*}{5 vruchtwisseling } & Volvelds & RDM & 30 & 2.1 & 2.0 & 0.82 & 4.69 \\
\hline & Volvelds & $\mathrm{K}-60$ & 0 & & & & \\
\hline & $\mathrm{Rij}$ & KAS & 100 & 27 & & & \\
\hline
\end{tabular}

Voor de inhoud van geoogste maïs is:

- $\quad 11.0 \mathrm{~kg} \mathrm{~N} /$ ton ds (op basis van Ruw Eiwit analyse 70.4/6.38) en 4.6 kgP2O5/ton ds (Blgg gem)

Voor de inhoud van geoogste gras/klaver is:

- $27 \mathrm{~kg} \mathrm{~N} /$ ton ds en $4.4 \mathrm{~kg} \mathrm{P2O5/ton} \mathrm{ds}$ 
Tabel 20. Aanvoer, afvoer en balans van stikstof en fosfaat per systeem in 2018.

\begin{tabular}{|c|c|c|c|c|}
\hline systeem & rij/volvelds & mestsoort & $\begin{array}{l}\text { kg N- } \\
\text { totaal/ha }\end{array}$ & $\mathrm{kg} \mathrm{P2O5/ha}$ \\
\hline \multirow[t]{3}{*}{ Gangbaar } & volvelds & RDM & 144 & 29 \\
\hline & rij & KAS & 59 & 0 \\
\hline & & totaal & 203 & 29 \\
\hline Maïs prod & ton ds/ha & 13.5 & 147 & 62 \\
\hline Balans & & & 56 & -33 \\
\hline \multirow[t]{4}{*}{ Org stof } & volvelds & RDM & 62 & 12 \\
\hline & volvelds & $\begin{array}{l}\text { groen } \\
\text { comp }\end{array}$ & 78 & 63 \\
\hline & rij & KAS & 57 & 0 \\
\hline & & totaal & 196 & 76 \\
\hline Maïs prod & ton ds/ha & 17.5 & 186 & 81 \\
\hline Balans & & & 11 & -5 \\
\hline \multirow[t]{3}{*}{ Kringloop } & rij & $\begin{array}{l}\text { dunne } \\
\text { fractie }\end{array}$ & 175 & 61 \\
\hline & rij & KAS & 0 & 0 \\
\hline & & totaal & 175 & 61 \\
\hline Maïs prod & ton ds/ha & 17.4 & 171 & 80 \\
\hline Balans & & & 4 & -20 \\
\hline \multirow[t]{5}{*}{ Twee oogsten } & Volvelds & RDM & 78 & 23 \\
\hline & volvelds & KAS & 27 & 0 \\
\hline & Rij & RDM & 82 & 16 \\
\hline & Volvelds & KAS & 27 & 0 \\
\hline & & totaal & 217 & 39 \\
\hline Maïs prod & ton ds/ha & 11.1 & 101 & 51 \\
\hline Gras prod & ton ds/ha & 2.0 & 37 & 9 \\
\hline Balans & & & 79 & -21 \\
\hline Vruchtwisseling & volvelds & RDM & 123 & 25 \\
\hline \multirow[t]{2}{*}{ Maïs } & volvelds & KAS & 27 & 0 \\
\hline & & totaal & 150 & 25 \\
\hline Maïs prod & ton ds/ha & 17.9 & 166 & 82 \\
\hline Balans & & & -16 & -58 \\
\hline
\end{tabular}




\subsection{Berekening organische stofbalans 2018}

\begin{tabular}{|c|c|c|c|}
\hline & Product & Hoeveelheid & Eenheid \\
\hline \multirow[t]{9}{*}{ Aanvoer } & Rundveedrijfmest & 0.7 & kg EOS per kg org. stof \\
\hline & Dunne fractie & 0.4 & kg EOS per kg org. stof \\
\hline & Compost & 0.75 & kg EOS per kg org. stof \\
\hline & Gewasresten snijmais & 675 & kg EOS per ha (bij ds opbrengst van 15 ton/ha) \\
\hline & Rogge vanggewas & 280 & $\mathrm{~kg}$ EOS per ton ds bovengrondse opbrengst \\
\hline & It. raaigras vanggewas & 360 & $\mathrm{~kg}$ EOS per ton ds bovengrondse opbrengst \\
\hline & It. raaigras maaien & 230 & $\mathrm{~kg}$ EOS per ton ds bovengrondse opbrengst \\
\hline & Opbouw gras $1^{\mathrm{e}}$ jaar & 875 & $\mathrm{~kg}$ EOS per ha \\
\hline & Opbouw gras $2^{\mathrm{e}}$ jaar & 2275 & kg EOS per ha \\
\hline \multirow[t]{4}{*}{ Afbraak } & Org. stofgehalte Rolde & 3.1 & $\%$ \\
\hline & Bij volvelds grondbewerking & 2 & $\%$ per jaar \\
\hline & Zonder grondbewerking & 1 & $\%$ per jaar \\
\hline & Bij gedeeltelijke grondbewerking & $1-2$ & $\%$ per jaar \\
\hline
\end{tabular}
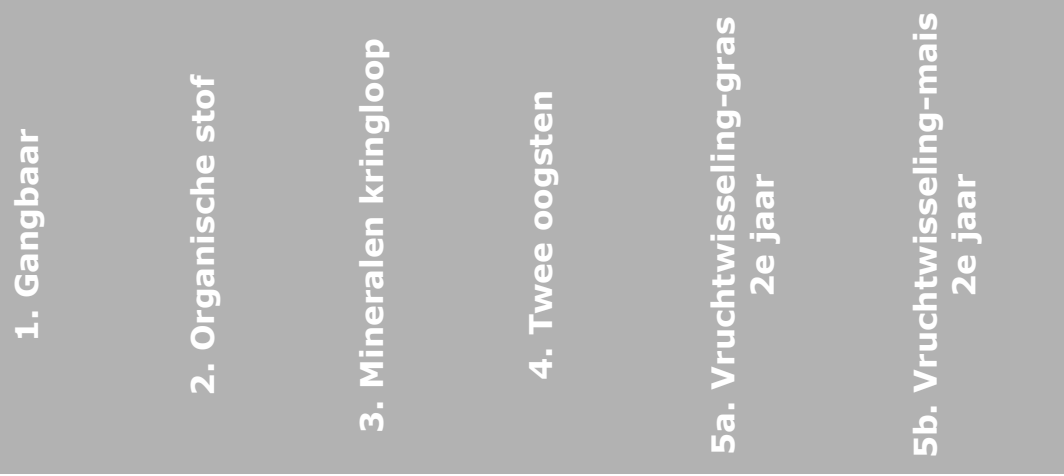

Aanvoer

\begin{tabular}{|c|c|c|c|c|c|c|}
\hline Gewasresten & 567 & 735 & 731 & 466 & 0 & 752 \\
\hline Organische mest & 1855 & 3615 & 675 & 2120 & 3180 & 1590 \\
\hline Groenbemester/tussengewas & 21 & 108 & 180 & 1335 & 2275 & 27 \\
\hline Totaal aanvoer & 2443 & 4458 & 1586 & 3921 & 5455 & 2369 \\
\hline Afbraak & 2100 & 1523 & 1838 & 1176 & 0 & 2100 \\
\hline Overschot/tekort & 343 & 2936 & -252 & 2745 & 5455 & 269 \\
\hline Factor & 0.7 & 5.9 & -0.5 & 5.5 & 10.9 & 0.5 \\
\hline score & + & +++++ & - & +++++ & ++++++++ & + \\
\hline
\end{tabular}


9.4 Milieubelastingspunten 2018

\begin{tabular}{|c|c|c|c|c|c|}
\hline Systeem & Middel en dosering & Actieve stof & $\begin{array}{l}\text { MBP water } \\
\text { organismen }\end{array}$ & $\begin{array}{l}\text { MBP bodem } \\
\text { organismen }\end{array}$ & $\begin{array}{l}\text { MBP } \\
\text { grondwater }\end{array}$ \\
\hline \multirow[t]{5}{*}{1 Gangbaar } & 3 Roundup & 1.08 & 6 & 12 & - \\
\hline & 0.75 Samson OD & 0.045 & 105 & 7.5 & 22.5 \\
\hline & 1.5 Calaris & 0.6 & 134 & 66 & 69 \\
\hline & 1 Frontier & 0.64 & 95.76 & 6.65 & 0 \\
\hline & totaal & 2.36 & 340 & 92 & 92 \\
\hline \multirow[t]{4}{*}{ 2. Organische stof } & 3 Roundup & 1.08 & 6 & 12 & 0 \\
\hline & 0.5 Samson OD & 0.03 & 70 & 5 & 15 \\
\hline & 0.5 Calaris & 0.2 & 45 & 22 & 23 \\
\hline & totaal & 1.31 & 121 & 39 & 38 \\
\hline \multirow[t]{4}{*}{ 3. Mineralen kringloop } & 3 Roundup & 1.08 & 6 & 12 & 0 \\
\hline & 0.5 Samson OD & 0.03 & 70 & 5 & 15 \\
\hline & 0.5 Calaris & 0.2 & 45 & 22 & 23 \\
\hline & totaal & 1.31 & 121 & 39 & 38 \\
\hline \multirow[t]{3}{*}{ 4. Twee oogsten } & 4 Roundup & 1.44 & 8 & 16 & 0 \\
\hline & 0.5 Calaris & 0.2 & 44.5 & 22 & 23 \\
\hline & totaal & 1.64 & 52.5 & 38 & 23 \\
\hline \multirow[t]{4}{*}{ 5. Vruchtwisseling (mais) } & 3 Roundup & 1.08 & 6 & 12 & 0 \\
\hline & 0.5 Samson OD & 0.03 & 70 & 5 & 15 \\
\hline & 0.5 Calaris & 0.2 & 45 & 22 & 23 \\
\hline & totaal & 1.31 & 121 & 39 & 38 \\
\hline
\end{tabular}




\subsection{Saldoberekeningen 2018}

\section{Opbrengsten}

\begin{tabular}{lcccccc} 
Hoofdgewas & $€ 3,160$ & $€ 4,002$ & $€ 3,929$ & $€ 2,414$ & $€ 1,703$ & $€ 3,908$ \\
\hline Groenbemester/nagewas & $€ 0$ & $€ 0$ & $€ 0$ & $€ 400$ & $€ 0$ & $€ 0$ \\
\hline
\end{tabular}

Subtotaal opbrengsten

$€ 3,160 € 4,002$

$€ 3,929$

$€ 2,814$

$€ 1,703$

$€ 3,908$

\section{Middelen}

\begin{tabular}{|c|c|c|c|c|c|c|}
\hline Zaaizaad (maïs +groenbemester) & $€ 246$ & $€ 264$ & $€ 264$ & $€ 264$ & $€ 49$ & $€ 264$ \\
\hline Meststoffen & $€ 119$ & $€ 309$ & $€ 204$ & $€ 165$ & $€ 229$ & $€ 159$ \\
\hline Gewasbeschermingsmiddelen & $€ 133$ & $€ 61$ & $€ 61$ & $€ 45$ & $€ 0$ & $€ 61$ \\
\hline Subtotaal middelen & $€ 497$ & $€ 634$ & $€ 529$ & $€ 474$ & $€ 277$ & $€ 483$ \\
\hline \multicolumn{7}{|l|}{ Loonwerk } \\
\hline Meststoffen aanwenden & $€ 132$ & $€ 170$ & $€ 207$ & $€ 201$ & $€ 303$ & $€ 130$ \\
\hline Hoofdgrondbewerking incl. zaaiklaar & $€ 128$ & $€ 70$ & $€ 85$ & $€ 210$ & $€ 0$ & $€ 105$ \\
\hline $\begin{array}{l}\text { Zaaien (maïs +groenbemester/ } \\
\text { nagewas) }\end{array}$ & $€ 113$ & $€ 143$ & $€ 143$ & $€ 35$ & $€ 48$ & $€ 143$ \\
\hline Spuiten & $€ 76$ & $€ 76$ & $€ 76$ & $€ 76$ & $€ 0$ & $€ 76$ \\
\hline Mechanische onkr.bestr & $€ 65$ & $€ 0$ & $€ 0$ & $€ 0$ & $€ 0$ & $€ 0$ \\
\hline $\begin{array}{l}\text { Oogsten (hoofdgewas+ } \\
\text { groenbemester) }\end{array}$ & $€ 435$ & $€ 435$ & $€ 435$ & $€ 552$ & $€ 468$ & $€ 435$ \\
\hline Stoppelbewerking & $€ 55$ & $€ 0$ & $€ 0$ & $€ 55$ & $€ 0$ & $€ 0$ \\
\hline Subtotaal loonwerk & $€ 1,004$ & $€ 894$ & $€ 946$ & $€ 1,129$ & $€ 818$ & $€ 889$ \\
\hline Totaal opbrengsten & $€ 3,160$ & $€ 4,002$ & $€ 3,929$ & $€ 2,814$ & $€ 1,703$ & $€ 3,908$ \\
\hline Totaal kosten & $€ 1,502$ & $€ 1,528$ & $€ 1,475$ & $€ 1,603$ & $€ 1,096$ & $€ 1,373$ \\
\hline Saldo & $€ 1,658$ & $€ 2,474$ & $€ 2,455$ & $€ 1,211$ & $€ 608$ & $€ 2,536$ \\
\hline
\end{tabular}




\subsection{Bodemparameters per systeem 2014}

\begin{tabular}{|c|c|c|c|c|c|c|}
\hline & & Standaard & Organische stof & Mineralen uit kringloop & Twee oogsten & Vruchtwisseling \\
\hline Parameter & Eenheid & & & & & \\
\hline $\mathrm{N}$-voorraad & $\mathrm{mg} / \mathrm{kg}$ grond & 840 & 1040 & 960 & 1000 & 1020 \\
\hline $\mathrm{CN}$ & ratio & 19 & 17 & 19 & 17 & 19 \\
\hline NLV & $\mathrm{Kg} / \mathrm{ha}$ jaar & 28 & 41 & 32 & 40 & 34 \\
\hline S-voorraad & $\mathrm{mg} / \mathrm{kg}$ grond & 160 & 160 & 170 & 170 & 180 \\
\hline CS & ratio & 98 & 109 & 106 & 99 & 106 \\
\hline SLV & $\mathrm{Kg} / \mathrm{ha} \mathrm{jaar}$ & 5 & 4 & 5 & 5 & 5 \\
\hline PPAE & $\mathrm{mg} / \mathrm{kg}$ grond & 1.4 & 3.9 & 2.8 & 1 & 2.1 \\
\hline P-AL & $\mathrm{mg}$ P2O5/100 gr grond & 51 & 55 & 55 & 56 & 58 \\
\hline K-PAE & $\mathrm{mg} \mathrm{K} / \mathrm{kg}$ & 33 & 64 & 44 & 51 & 54 \\
\hline $\mathrm{K}$ vrd & $\mathrm{mmol}+/ \mathrm{kg}$ & 1.9 & 2.2 & 1.8 & 2.1 & 2.3 \\
\hline $\mathrm{Mg}-\mathrm{PAE}$ & $\mathrm{mg} / \mathrm{kg}$ grond & 35 & 43 & 41 & 41 & 71 \\
\hline $\mathrm{pH}$ & & 4.9 & 5.1 & 5.1 & 5 & 4.9 \\
\hline o.s. & $\%$ & 2.7 & 3.0 & 3.1 & 2.9 & 3.3 \\
\hline K-getal & berekend & 9 & 15 & 12 & 14 & 14 \\
\hline
\end{tabular}




\subsection{Bodemparameters per systeem 2018}

\begin{tabular}{|c|c|c|c|c|c|c|}
\hline & & Standaard & Organische stof & Mineralen uit kringloop & Twee oogsten & Vruchtwisseling \\
\hline Parameter & Eenheid & & & & & \\
\hline $\mathrm{N}$-voorraad & $\mathrm{mg} / \mathrm{kg}$ grond & 3390 & 3460 & 3500 & 4000 & 3740 \\
\hline $\mathrm{CN}$ & ratio & 16 & 17 & 18 & 16 & 18 \\
\hline NLV & $\mathrm{Kg} / \mathrm{ha}$ jaar & 45 & 40 & 40 & 50 & 40 \\
\hline S-voorraad & $\mathrm{mg} / \mathrm{kg}$ grond & 590 & 650 & 645 & 680 & 705 \\
\hline CS & ratio & 92 & 92 & 98 & 96 & 97 \\
\hline SLV & $\mathrm{Kg} / \mathrm{ha}$ jaar & 6 & 7 & 6 & 7 & 7 \\
\hline PPAE & $\mathrm{mg} / \mathrm{kg}$ grond & 2.8 & 4.1 & 3.1 & 2.4 & 3 \\
\hline P-AL & $\mathrm{mg} \mathrm{P} 205 / 100$ gr grond & 49 & 50 & 51 & 48 & 52 \\
\hline K-PAE & $\mathrm{mg} \mathrm{K} / \mathrm{kg}$ & 64 & 72 & 49 & 70 & 74 \\
\hline K vrd & $\mathrm{mmol}+/ \mathrm{kg}$ & 365 & 375 & 370 & 370 & 340 \\
\hline Mg-PAE & $\mathrm{mg} / \mathrm{kg}$ grond & 33 & 44 & 57 & 47 & 65 \\
\hline $\mathrm{pH}$ & & 5 & 5.3 & 5.4 & 5.3 & 5.8 \\
\hline o.s. & $\%$ & 2.7 & 3 & 3.2 & 3.3 & 3.5 \\
\hline K-getal & berekend & 16 & 17 & 12 & 17 & 18 \\
\hline
\end{tabular}




\subsection{Effect van teeltsystemen op (biologische) bodemparameters}

In het voor jaar van 2012, voorafgaand aan het aanleggen van de systeemvarianten is een T-nul bemonstering aan de bodem uitgevoerd. Doel van de $T$ nul bemonstering was om met een aantal chemische, fysische en biologische waarnemingen de uitgangssituatie vast te leggen. Door deze waarnemingen in de tijd te herhalen wordt een indruk verkregen van de effecten van de verschillende teeltsystemen op deze bodemparameters. In oktober 2014 zijn alle systemen op de twee locaties nogmaals bemonsterd. De resultaten van deze twee bemonsteringen zijn weergegeven in het rapport "Grondig Boeren met Maïs; metingen aan biologische en chemische (fysische) bodemparameters (mrt 2015). In november 2016 en herhaald in februari 2019 zijn twee teeltsystemen in de demo te Rolde opnieuw bemonsterd. Het standaard-systeem en het organische stof systeem. Om budgettaire reden konden niet alle systemen en alle parameters (die in 2014 zijn bepaald) worden geanalyseerd maar is er een selectie gemaakt van de, naar verwachting, meest interessante parameters.

\subsubsection{Uitvoering}

Op 3 november 2016 en 13 februari 2019 zijn de systemen standaard en organische stof bemonsterd. Per systeem is een duplo-bepaling uitgevoerd. In elke strook (systeem) zijn twee plots van $18 \times 15 \mathrm{~m}$ uitgezet en bemonsterd (zie schema). Uit elke plot is met een $13 \mathrm{~mm}$ boor circa drie liter grond uit de laag $0-30 \mathrm{~cm}$ verzameld. Elk grondmonster is gemengd en opgesplitst in drie submonsters en aangeboden aan de verschillende laboratoria voor analyse op verschillende bodemparameters (zie onderstaand overzicht).

Tabel 21. Bodemparameters gemeten in systemendemo Grondig boeren met Mais Drenthe

\begin{tabular}{|c|c|}
\hline Analyse & Uitvoerende instantie \\
\hline Chemische bodemvruchtbaarheid & Eurofins \\
\hline Millieuaaltjes & Eurofins \\
\hline Microbiologische bodemparameters & Wageningen Environmental Research (Alterra) \\
\hline Schimmelbiomassa & \\
\hline Bacterie-biomassa & \\
\hline Hot Water extractable Carbon (HWC) & \\
\hline
\end{tabular}

\subsubsection{Chemische bodemvruchtbaarheid}

De analyses op chemische bodemvruchtbaarheid zijn uitgevoerd door Eurofins. In Tabel 22 zijn de resultaten van de analyse op bodemvruchtbaarheid gemiddelden per systeem, voor de monstername in november 2016 en februari 2019 weergegeven en de streefwaarden zoals Eurofins die hanteert.

Vergeleken met de streefwaarden die Eurofins hanteert liggen voor beide systemen en beide meetmomenten het gemiddeld $\mathrm{N}$ - en $\mathrm{S}$ leverend vermogen en $\mathrm{P}$-beschikbaar (P-PAE) onder deze streef waarden. Voor systeem standaard zijn ook de waarden voor K-beschikbaar (K-PAE), Cabeschikbaar en $\mathrm{Mg}$-beschikbaar lager dan de streefwaarden die Eurofins opgeeft. Met uitzondering van het standaard systeem-bemonstering febr. 2019 zijn de C/S-ratio en de K- en P-voorraad wat hoger dan deze streefwaarden. 


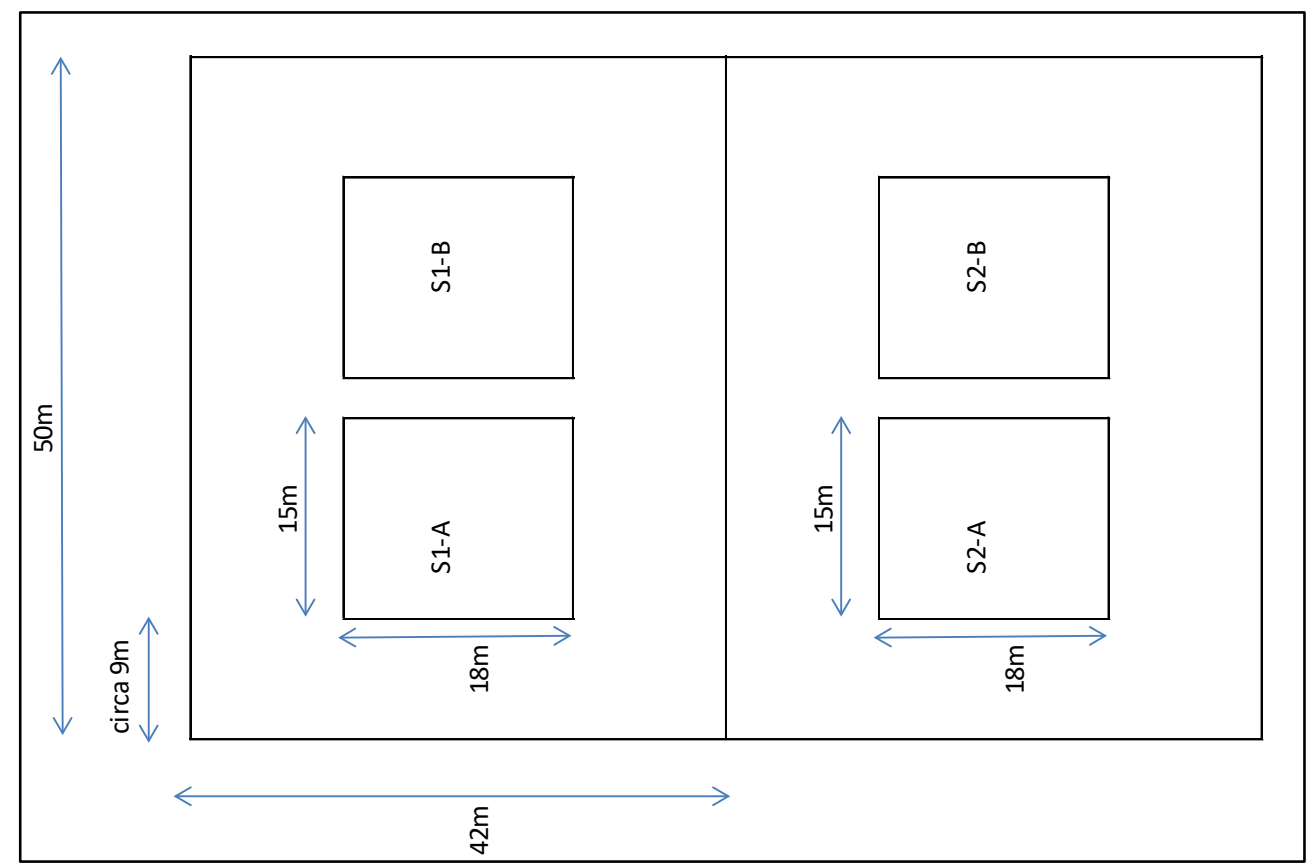

Figuur 38. Schematische weergave van de bemonsteringsplots. Links systeem standaard, rechts systeem organische stof.

In onderstaande figuur is een vergelijking gemaakt tussen de twee systemen en de twee bemonsteringsmomenten. In Figuur 30 is het systeem organische stof relatief ten opzichte van het systeem STANDAARD weergegeven. Voor alle parameters geldt dat de waarden gemeten in systeem organische stof hoger zijn dan in systeem STANDAARD met uitzondering van Ca-beschikbaar in febr. 2019 en Na-beschikbaar in nov. 2016. De bodemvruchtbaarheid onder het organische stof systeem is iets beter als onder het standaard systeem, maar de verandering in de tijd (2016-2019) is klein. Ook in de metingen van 2014 en 2012 was er al een verschil tussen systeem standaard en het organische stof systeem, ten gunste van het organische stof systeem.
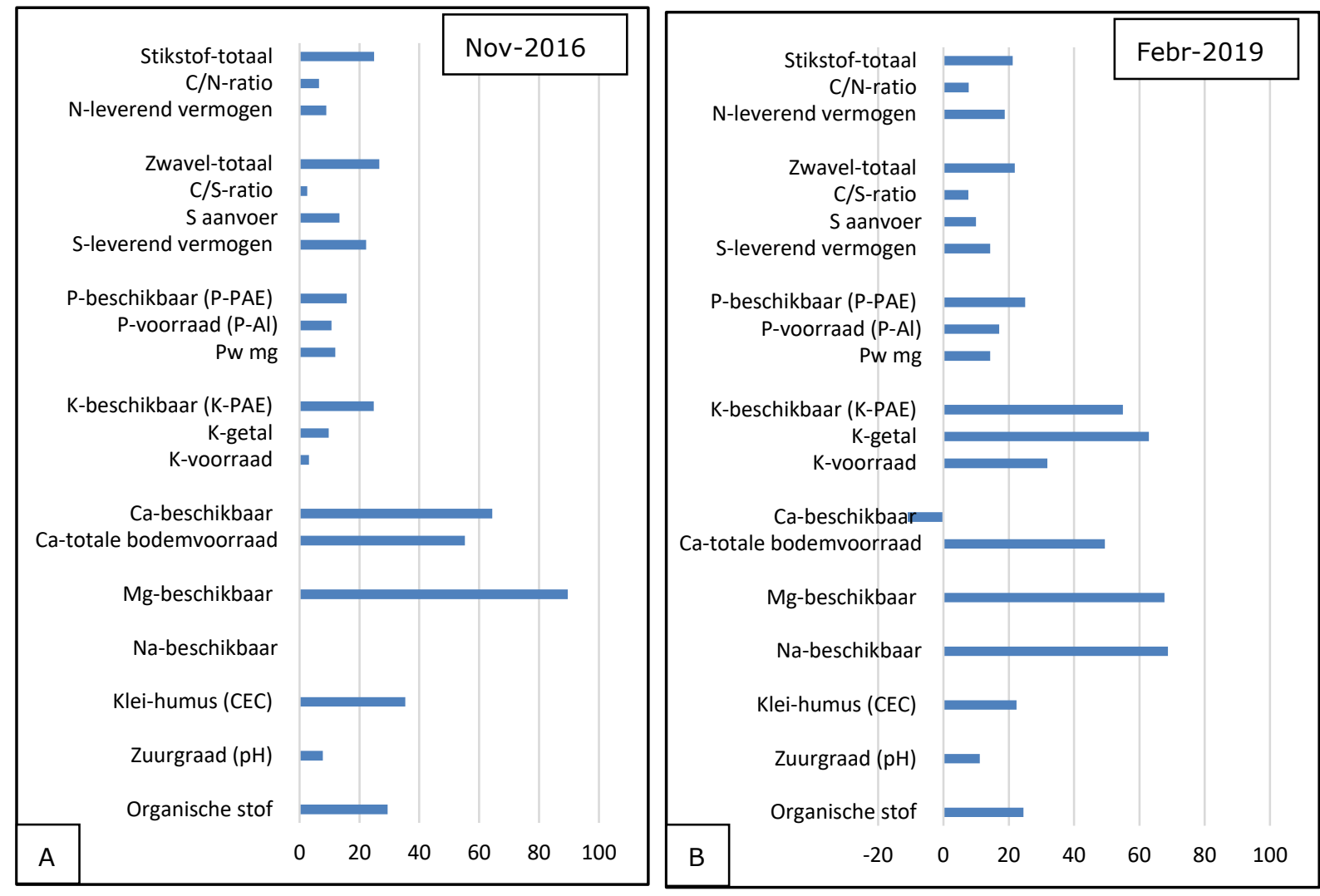

Figuur 39. Bodemvruchtbaarheid systeem organische stof relatief ten opzichte van systeem standaard. Links (A) resultaten 2016, rechts (B) resultaten 2019. 
In Figuur 31 zijn de metingen van febr. 2019 relatief t. o. v. nov. 2016 weergegeven. Voor beide systemen geldt dat de waarden voor S-aanvoer en S-leverend vermogen in febr. 2019 iets hoger zijn dan in nov. 2016 maar nog onder de streefwaarden liggen. De Ca-beschikbaar is in beide systemen in febr. 2019 lager dan in nov. 2016 en ligt nu onder de streefwaarde van Eurofins. Voor de andere elementen zijn er kleine toe of afnames te zien tussen de nov. 2016 en febr. 2019 meting. In systeem ORG. STOF is Na-beschikbaar in febr. 2019 duidelijk hoger dan in nov. 2016 maar ligt nog ruim onder de streefwaarde van Eurofins. Een verklaring voor deze verandering zou kunnen zijn: veranderende samenstelling van de toegediende compost ( $\mathrm{K}$ en $\mathrm{Na}$ ).

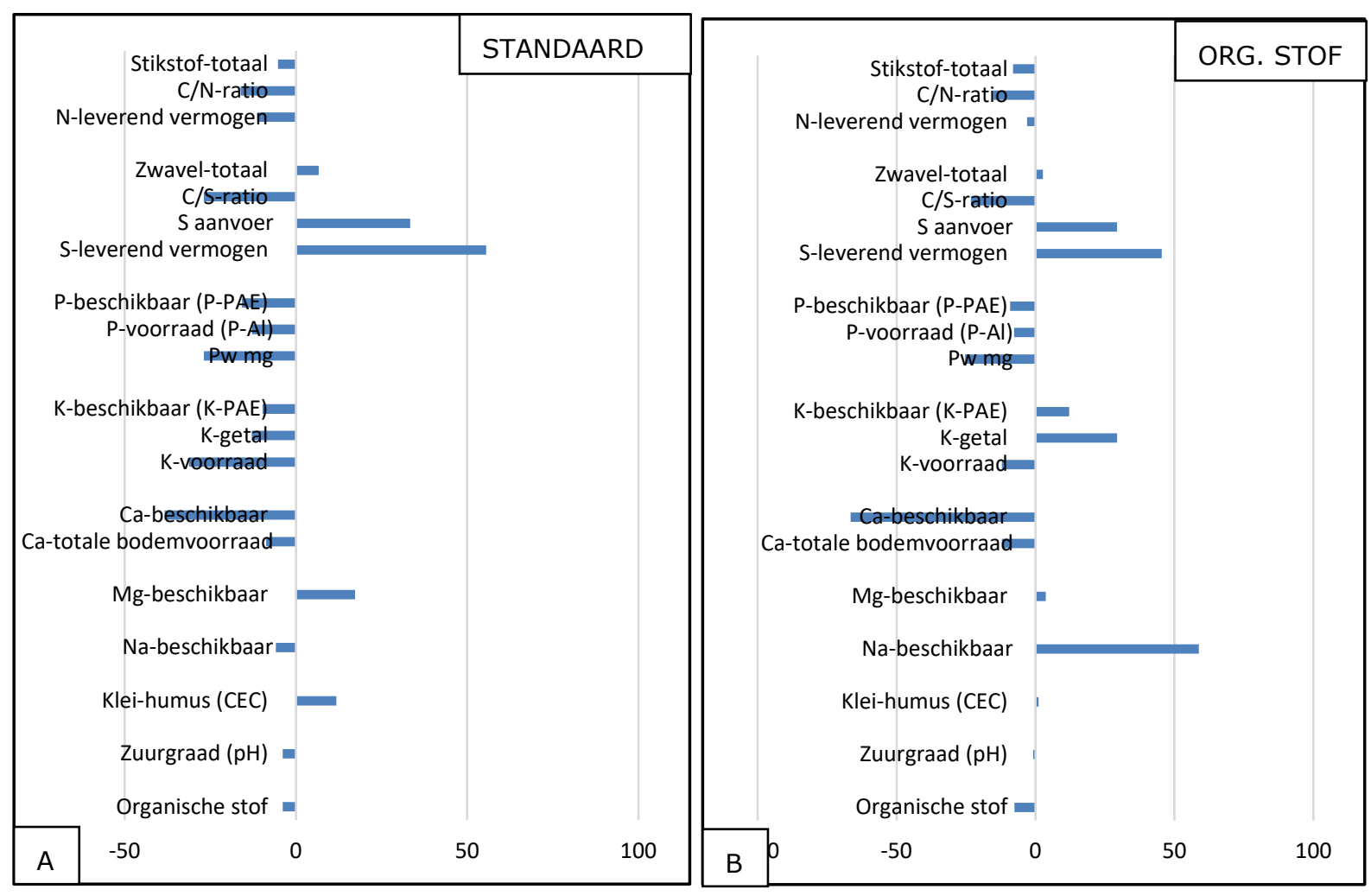

Figuur 40. Bodemvruchtbaarheid relatief ten opzichte van de tijd (2019 tov 2016). Links (A) systeem standaard, rechts $(B)$ systeem organische stof.

Het organisch stofgehalte in systeem organische stof (gem. 3.2\%) is wat hoger dan in systeem STANDAARD (gem. 2.6\%). Veranderingen in organisch stofgehalte als gevolg van teeltmaatregelen verlopen in het algemeen (erg) langzaam. Daarnaast was er ook al een verschil in organische stof gehalte bij aanvang van de demo. Het is daardoor aannemelijker dat het verschil tussen de systemen meer het gevolg is van variatie in het perceel (de strook waarop het systeem is aangelegd, systemen zijn in enkelvoud aangelegd) dan het effect van de teeltmaatregelen die de afgelopen jaren zijn uitgevoerd. Bemonsteringen in de toekomst zullen moeten uitwijzen of de verschillen tussen de systemen groter worden, en dan dus wel toegewezen kunnen worden als effect van de teeltmaatregelen. 
Tabel 22. Chemische bodemvruchtbaarheid, Grondig boeren met Mais Drenthe, nov 2016 en feb 2019.

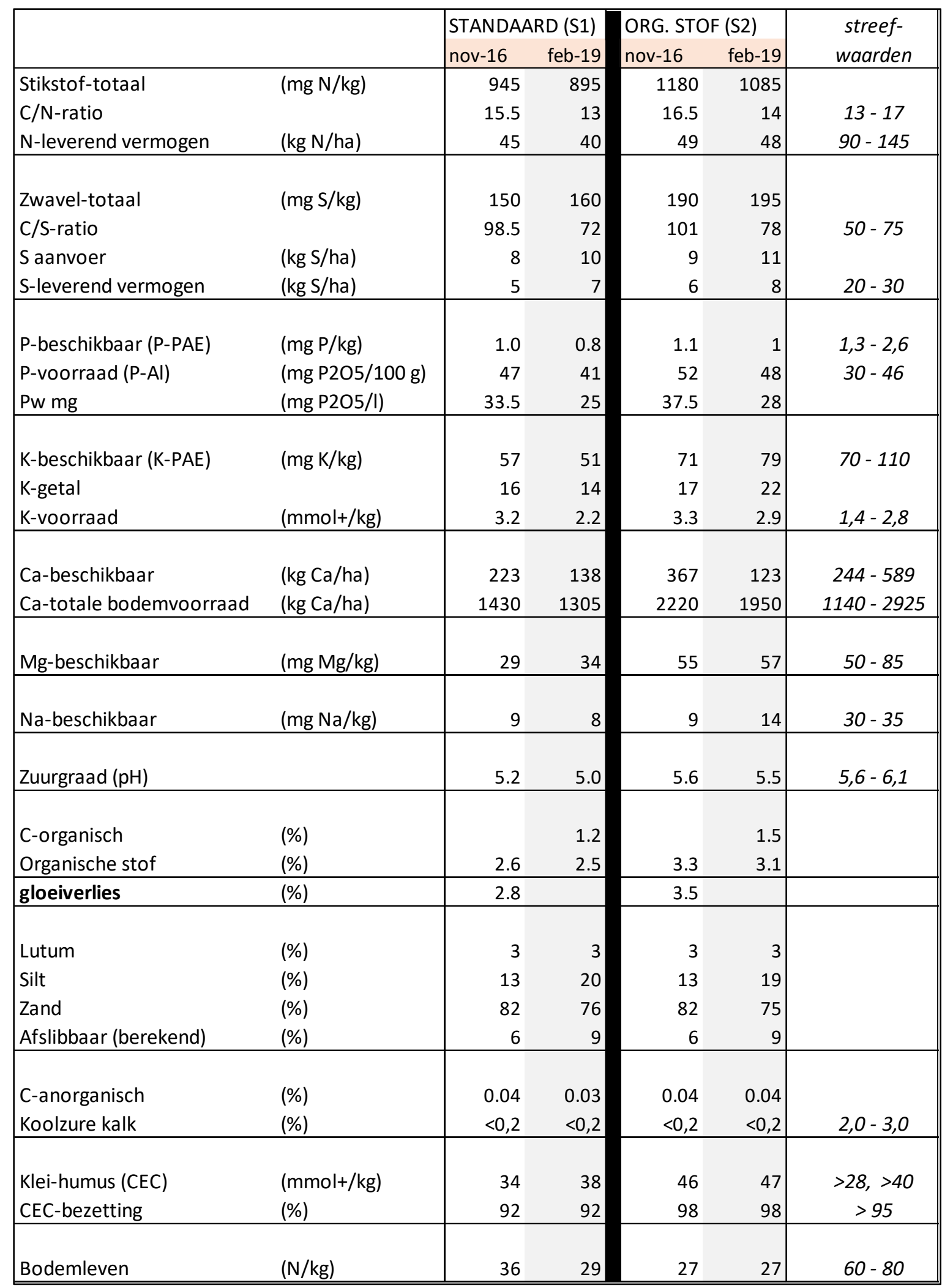




\subsubsection{Microbiologische parameters}

De monsters zijn op een aantal microbiologische parameters geanalyseerd; Potentieel mineraliseerbare N, HWC, schimmel- en bacterie biomassa (zie kader hieronder). De analyses van de verschillende microbiologische parameters zijn uitgevoerd door Wageningen Enviromental Research (Alterra).

Potentieel mineraliseerbare $\mathbf{N}$; is een maat voor gemakkelijk afbreekbare stikstof, en wordt wel gezien als een goed indicator voor de totale microbiologische biomassa en bodemvruchtbaarheid. De PMN correleert vaak met het organische stofgehalte en totaal $\mathrm{N}$ en $\mathrm{C}$, maar laat eerder en grotere verschillen zien. De hoeveelheid minerale stikstof (NH4-N) die vrijkomt bij de meting, is een indicatie voor de kwaliteit van de organische stof ( $\mathrm{N}$-gehalte en afbreekbaarheid) en daarmee voor de biologische bodemvruchtbaarheid. Hogere waarden wijzen op meer bodemleven en een grotere bodemvruchtbaarheid Hot water extractable C (HWC); is een onderdeel van de totale organische stof en is een maat voor gemakkelijk afbreekbare (labiele) organische koolstof. HWC bestaat voor een groot deel uit polysachariden (mucigel, slijm) die voornamelijk zijn uitgescheiden door micro-organismen en in mindere mate door plantenwortels. Deze verbindingen werken als kit (lijm) bij de vorming van micro-aggregaten die bijdragen aan een goede kruimelige bodemstructuur. HWC lijkt goed te correleren met microbiële koolstof en wordt wel gezien als een goede maat voor "bodemkwaliteit". Hogere waarden wijzen op meer bodemleven en een grotere bodemvruchtbaarheid

Schimmel biomassa; bodemschimmels zijn belangrijk voor nutriënten-kringloop, moeilijk afbreekbare organische stof (o.a. lignine), structuur van de bodem en zijn gevoelig voor grondbewerking

Bacteriële biomassa; bacteriën zijn belangrijk voor de bodem/bodemprocessen, spelen onder andere een rol bij de nutriënten-kringloop en structuur van de bodem.

In Figuur 32 en Figuur 33 zijn de resultaten voor potentieel mineraliseerbare stikstof (PMN), Hot Water-extractable Carbon (HWC), schimmelbiomassa en bacteriebiomassa van de bemonstering in oktober 2014, november 2016 en februari 2019 weergegeven.
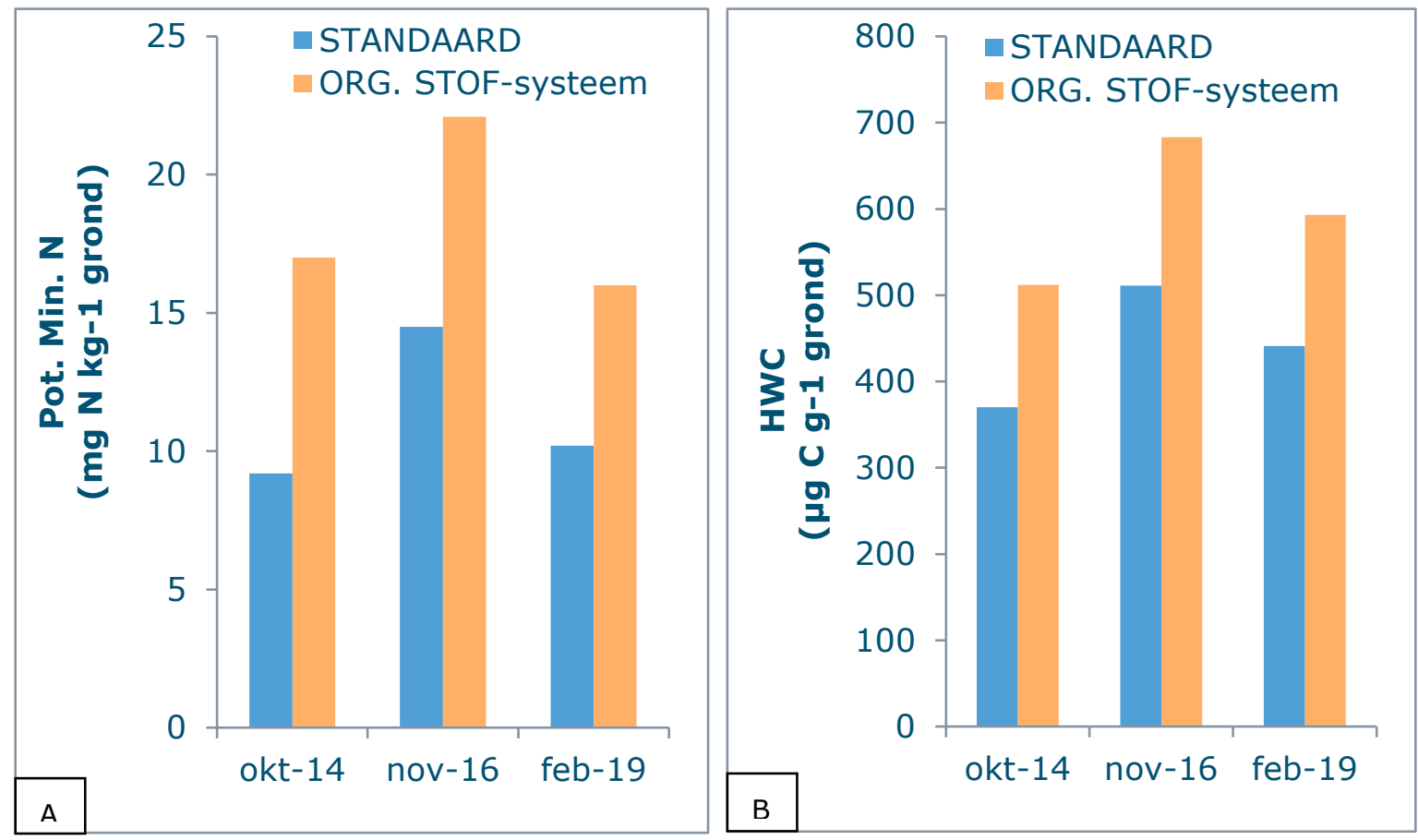

Figuur 41. Potentieel mineraliseerbare stikstof (links, A) en Hot water-extractable carbon (rechts, B) van systeem gangbaar en organische stof. 


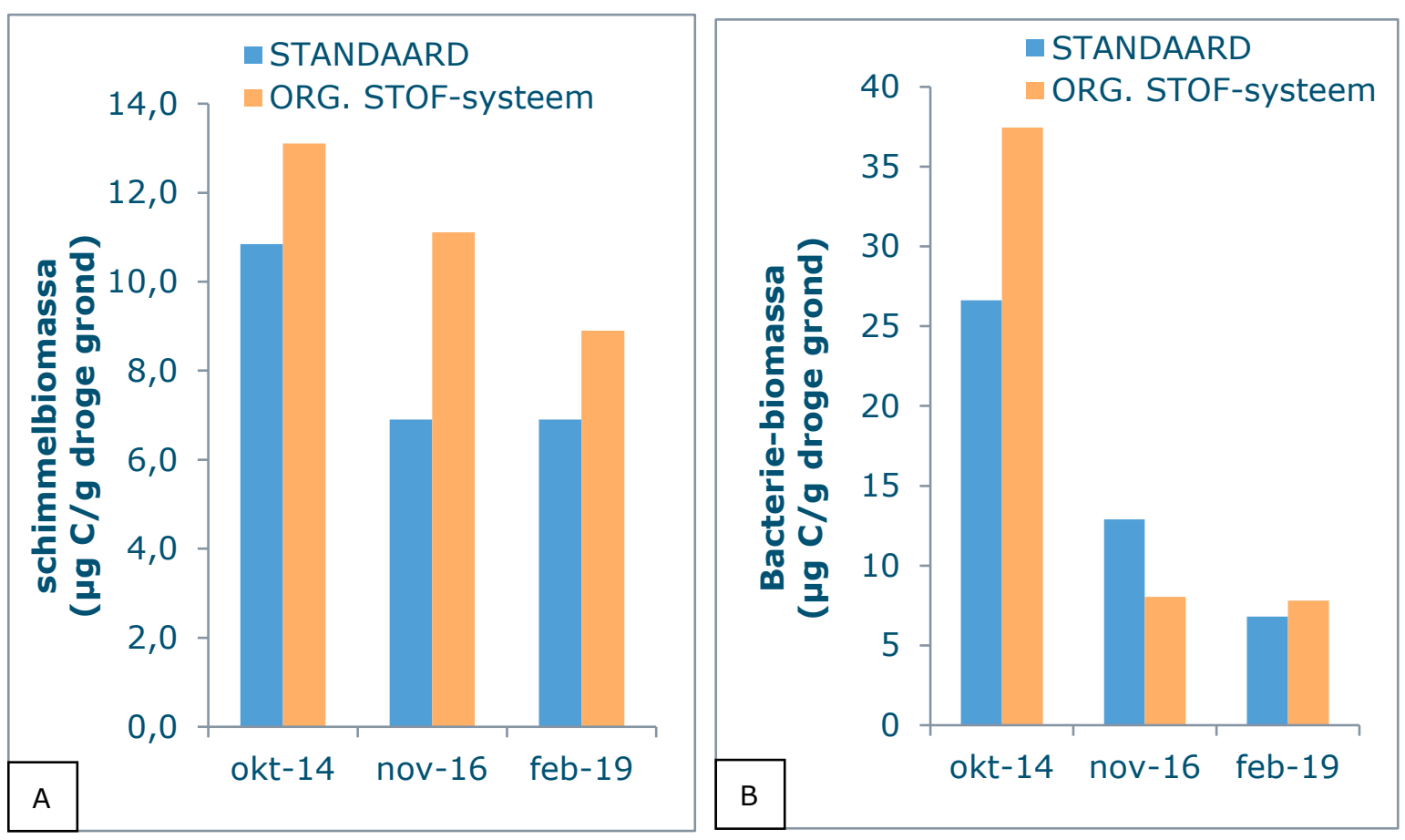

Figuur 42. Schimmelbiomassa (links, A) en bacteriebiomassa (rechts, B) in systeem standaard en systeem organische stof.

PMN en HWC worden gezien als goede indicatoren voor bodemleven (microbiologische biomassa) en bodemvruchtbaarheid. Bij alle monstermomenten (okt-14, nov-16 en febr-19) jaren zijn de waarden voor zowel PMN als HWC in het systeem ORG. STOF hoger dan in het STANDAARD systeem; wat zou duiden op een beter bodemleven en een hogere bodemvruchtbaarheid in systeem ORG. STOF (Figuur 32).

Het tijdstip van de monstername (tijdstip in het jaar en de tijd tussen oogst en monstername) heeft effect op de absolute waarden voor PMN en HWC. In nov. 2016 zijn PMN en HWC in beide systemen hoger dan in okt. 2014. In februari 2019 zijn de waarden voor PMN vergelijkbaar met die gemeten in oktober 2014 en liggen de waarden voor HWC tussen de waarden die in oktober 2014 en november 2016 zijn gemeten. Er is geen duidelijk trend waarneembaar over de jaren. De verschillen tussen de jaren zijn naar verwachting (voor een deel) het gevolg van verschillen in bemonsteringstijdstip.

Of de veranderingen in PMN en HWC in beide system het effect zijn van de gevoerde teeltstrategie of het gevolg van monstermoment zullen metingen in de komende jaren moeten uitwijzen, waarbij getracht moet worden om op een vast tijdstip in het jaar de bemonsteringen uit te voeren.

Evenals in okt 2014 is ook in nov. 2016 en febr. 2019 de totale schimmelbiomassa in het systeem ORG. STOF hoger dan in systeem STANDAARD. Het systeem ORG. STOF lijkt een positief effect te hebben op de schimmelbiomassa. Een hogere schimmelbiomassa kan duiden op meer moeilijk afbreekbare organische stof in de bodem, maar kan ook het gevolg zijn van minder intensieve grondbewerking.

De totale schimmelbiomassa lijkt in beide systemen af te nemen. De waarden voor schimmelbiomassa zijn echter laag (med. J. Bloem) waardoor effecten van monstermoment relatief groot kunnen zijn. De trend die nu zichtbaar lijkt (afname schimmelbiomassa) is mogelijk toe te schrijven aan het moment waarop is bemonsterd. In 2014 is de monsternamen al in oktober uitgevoerd, vrij kort na de oogst. In 2016 eind november en in 2019 is de monstername (pas) in februari uitgevoerd.

In febr. 2019 en okt. 2014 is de totale bacterie-biomassa in het systeem ORG. STOF (iets) hoger dan in systeem STANDAARD. In nov. 2016 is dit omgekeerd en wordt de hoogste bacterie-biomassa gemeten in het systeem STANDAARD. De systeem gemiddelden worden bij de "nov 2016 -meting" echter sterk beïnvloedt door één meetplot in systeem STANDAARD met een meetwaarde voor bacterie-biomassa die ruim tweemaal hoger is dan in de andere meetplots (in beide systemen). 
De totale bacterie-biomassa lijkt af te nemen in de tijd. Ook voor deze parameter geldt dat de trend die zichtbaar lijkt mogelijk voor een (groot) deel wordt veroorzaakt door verschillen tussen de jaren in tijdstip waarop bemonsterd is. Door de variatie in het perceel en mogelijk ook als gevolg van het monstermoment, is het (nog) niet mogelijk om betrouwbare effecten/trends van de systemen op de bacterie-biomassa vast te stellen.

\subsubsection{Milieu-aaltjes}

Het grootste deel van de aaltjespopulatie in de bodem bestaat uit niet plant parasitaire aaltjessoorten; de milieuaaltjes. Soorten die belangrijk zijn voor het ecosysteem in de bodem (eten en gegeten worden) en een rol spelen bij allerlei processen in de bodem.

Milieuaaltjes. De totale aaltjesgemeenschap die we in de bodem aantreffen is in te delen in verschillende voedselgroepen; schimmel- en bacterie-eters, omnivoren- en carnivore aaltjes en soorten die zich aan planten voeden.

Naast de indeling in voedselgroepen zijn nematoden op basis van levensstrategie in te delen in colonizer-persister groepen (cp-klassen, $1 \mathrm{t} / \mathrm{m} \mathrm{5}$ ). Aaltjessoorten met een lage $\mathrm{cp}$-waarde zijn "pioniers-soorten. Deze soorten reageren snel op veranderingen in hun leefmilieu en hebben een relatief korte levenscyclus (snelle voortplanting, korte levensduur). CP-1 soorten komen veel voor in voedselrijke en vaak meer verstoorde bodems. Nematoden die behoren tot $\mathrm{cp}-3$ tot en met $\mathrm{cp}-5$ klasse hebben een lange levensduur, zijn groter en vaak ook gevoeliger voor veranderingen en komen meer voor in stabiele(re) en rijpere bodems (ecosystemen). Landbouwgronden hebben gemiddeld een hoog percentage $\mathrm{cp}-1$ nematoden. Op basis van de aantallen per cp-klasse zijn indices te berekenen. Deze indices zijn indicatoren voor de conditie van de bodem(voedselrijkheid, verontreiniging, verstoord).

De analyse op milieuaaltjes is in 2016 uitgevoerd door Eurofins. De monsters die in februari 2019 zijn gestoken zijn door het lab van WUR-OT (Lelystad) geanalyseerd. In onderstaande figuren is de samenstelling van de aaltjespopulatie, op basis van voedselgroepen en cp-klasse weergegeven.
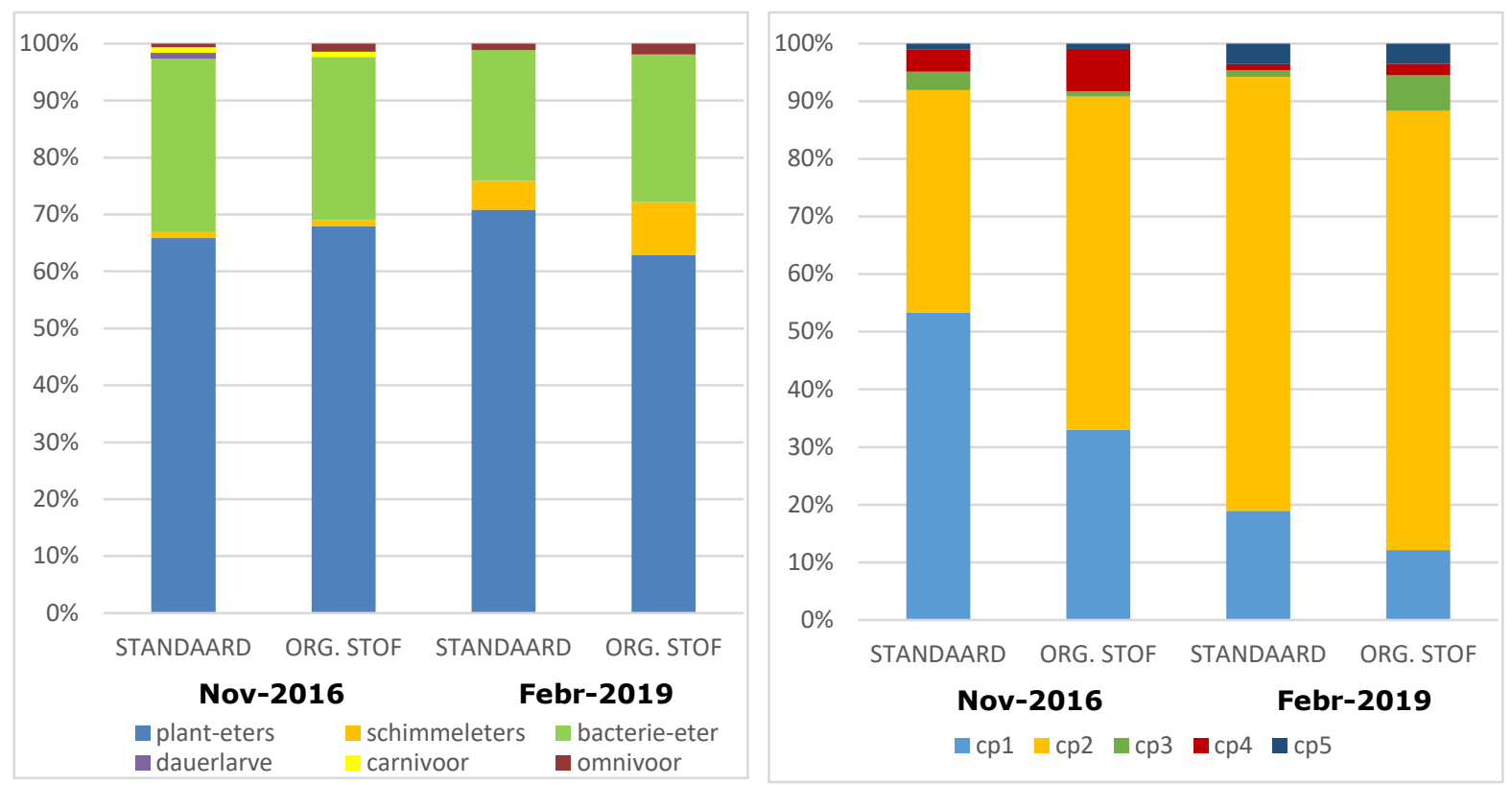

Figuur 43. Samenstelling nematodenpopulatie in beide systemen in 2016 en 2019.

In november 2016 is in beide systemen het totaal aantal nematoden per $100 \mathrm{ml}$ grond circa 1500 . In de februari 2019 meting is het totaal aantal nematoden in het STANDAARD systeem vergelijkbaar met nov. 2016. In het OS-systeem is het aantal wat hoger, ruim 1900 nematoden per 100 ml grond. 
Op basis van de indeling op voedselgroepen verschillen de systemen niet significant van elkaar. De aaltjespopulatie bestaat, in beide systemen en op beide meetmomenten, voor 65 tot 70 procent uit plant parasitaire aaltjes. Pratylenchus crenatus, het graanwortellesieaaltje is de meest dominante soort. De besmetting met plant parasitaire aaltjes bestaat voor meer dan $95 \%$ uit deze aaltjessoort. Mais is een goede waard voor het graanwortellesieaaltje maar voor zover bekend veroorzaakt dit aaltje geen schade in mais. Ook de verschillen tussen de twee monstermomenten zijn klein. In febr.2019 lijkt het aantal schimmel-eters iets hoger en bacterie-eters iets lager dan in nov. 2016. Maar verschillen zijn klein en enkel op basis van een duplo bepaling niet betrouwbaar vast te stellen.

Op basis van de indeling op cp-klasse zijn de verschillen tussen de systemen wat groter. Het aandeel cp1-nematoden is in systeem STANDAARD wat hoger dan in systeem ORG. STOF. Voor cp-2 nematoden is dit omgekeerd, een hoger aantal cp-2 nematoden in systeem ORG. STOF. Het verschil tussen de systemen voor deze cp-klassen is in nov. 2016 groter dan in febr. 2019.

Circa 90 procent van de aaltjesgemeenschap bestaat uit soorten die behoren tot de cp-klassen 1 en 2. Het aandeel cp-2 nematoden is in febr. 2019 gemiddeld groter dan in nov. 2016. Het percentage cp3, cp4 en cp5 aaltjes is in alle monsters gering en verschillen tussen systemen en jaren zijn voor deze cp-klassen dan ook zeer klein.

Meer nematoden in een hogere $\mathrm{cp}$-klasse duidt op een stabieler, minder verstoord, systeem. In systeem ORG. STOF is het aandeel nematoden met een hogere cp-klasse iets groter. De verschillen tussen de systemen zijn echter (nog) te klein om hier al conclusie over systeem-effecten aan te verbinden.

Op basis van de aantallen nematoden per cp-klasse zijn indexen te berekenen. De Maturity Index (MI) is een maat voor de "stabiliteit" van de bodem. Meer verstoorde en verrijkte (nutriënt-rijke) bodems hebben een lage MI (1). Een hoge MI waarde (5) duidt op een meer stabiele (rijpe) bodem. Landbouwgronden, waarbij het bodemleven wordt verstoord als gevolg van o.a. grondbewerking en bemesting, hebben een MI van circa 2. De MI van beide systemen is laag. De MI van systeem ORG. STOF is iets hoger (1,9 in nov. 2016 en 2.1 in febr. 2019) dan van systeem STANDAARD (resp. 1,6 en 1.9) maar het verschil tussen de systemen en ook de jaren is klein. Er dan ook nog geen duidelijk effect van de systemen en/of jaren op de MI waar te nemen.

In Figuur 35 is de Structure Index (SI) uitgezet tegen de Enrichment Index (EI). De waarden liggen voor alle metingen, met uitzondering van de metingen in het systeem ORG. STOF in okt 2014 en febr. 2019 , in het kwadrant links boven. Een kwadrant dat wordt getypeerd als verrijkt en meer verstoord. $\mathrm{Er}$ is geen duidelijk trend in de tijd waar te nemen en met uitzondering van okt-2014 liggen de systemen vrij dicht bij elkaar.

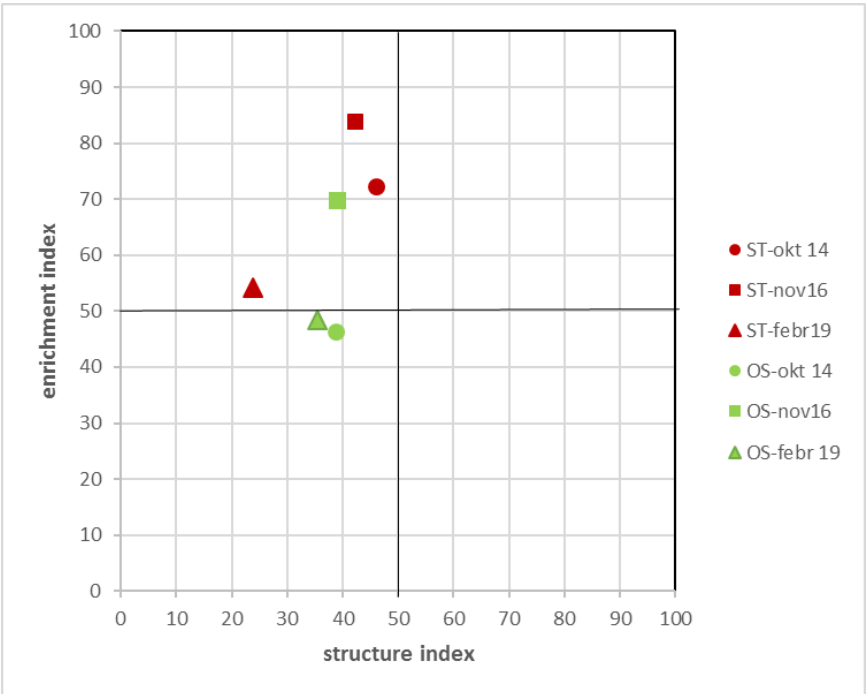

Foodweb analysis: interpretation scheme

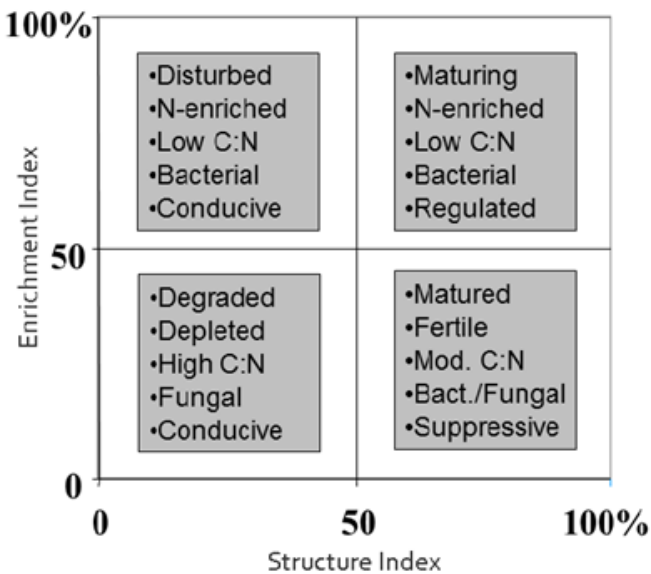

Figuur 44. Indexen berekend op basis van de samenstelling van de nematodenpopulatie voor de twee systemen in 2014, 2016, 2019. (bron: NINJA: Nematode INdicator Joint Analysis, http://spark.rstudio.com/bsierieb/ninja/) 


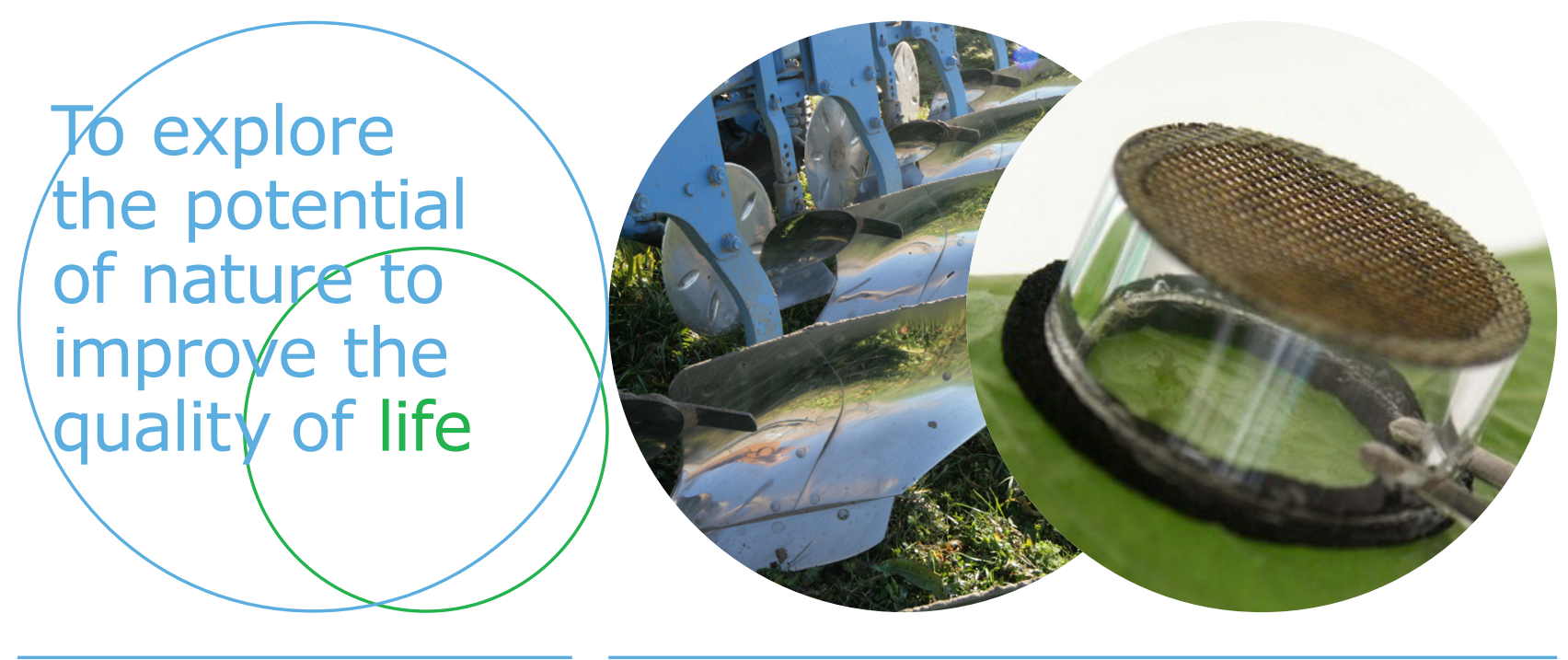

Correspondentie adres voor dit rapport: Wageningen University \& Research | Open Teelten

Edelhertweg 1

Postbus 430

8200 AK Lelystad

T (+31)320 291111

www.wur.nI/openteelten

Rapport WPR-809
De missie van Wageningen University \& Research is 'To explore the potential of nature to improve the quality of life'. Binnen Wageningen University \& Research bundelen 9 gespecialiseerde onderzoeksinstituten van stichting DLO en Wageningen University hun krachten om bij te dragen aan de oplossing van belangrijke vragen in het domein van gezonde voeding en leefomgeving. Met ongeveer 30 vestigingen, 6.000 medewerkers en 9.000 studenten behoort Wageningen University \& Research wereldwijd tot de aansprekende kennisinstellingen binnen haar domein.

De integrale benadering van de vraagstukken en de samenwerking tussen verschillende disciplines vormen het hart van de unieke Wageningen aanpak. 